\title{
Formação de professores
}

limites contemporâneos e alternativas necessárias

\author{
Lígia Márcia Martins \\ Newton Duarte \\ (orgs.)
}

MARTINS, LM., and DUARTE, N., orgs. Formação de professores: limites contemporâneos e alternativas necessárias [online]. São Paulo: Editora UNESP; São Paulo: Cultura Acadêmica, 2010. 191 p. ISBN 978-85-7983-103-4. Available from SciELO Books <http://books.scielo.org>.

\section{(1)(1)(2)}

All the contents of this work, except where otherwise noted, is licensed under a Creative Commons Attribution-Non Commercial-ShareAlike 3.0 Unported.

Todo o conteúdo deste trabalho, exceto quando houver ressalva, é publicado sob a licença Creative Commons Atribuição Uso Não Comercial - Partilha nos Mesmos Termos 3.0 Não adaptada.

Todo el contenido de esta obra, excepto donde se indique lo contrario, está bajo licencia de la licencia Creative Commons Reconocimento-NoComercial-CompartirIgual 3.0 Unported. 


\section{FormaçÃo DE PROFESSORES}


CONSELHO EDITORIAL ACADÊMICO

Responsável pela publicação desta obra

Luci Pastor Manzoli

Paula Ramos de Oliveira

Elaine Cristina Scarlatto (discente) 


\title{
LÍGIA MÁRCIA MARTINS NEWTON DUARTE \\ (Orgs.)
}

\section{FormaÇÃO \\ DE PROFESSORES}

\section{LIMITES CONTEMPORÂNEOS E ALTERNATIVAS NECESSÁRIAS}

\author{
Apoio técnico: \\ Ana Carolina Galvão Marsiglia
}


(C) 2010 Editora UNESP

\section{Cultura Acadêmica}

Praça da Sé, 108

01001-900 - São Paulo - SP

Tel.: (0xx11) 3242-7171

Fax: (0xx11) 3242-7172

www.editoraunesp.com.br

feu@editora.unesp.br

CIP - Brasil. Catalogação na fonte

Sindicato Nacional dos Editores de Livros, RJ

F82

Formação de professores: limites contemporâneos e alternativas necessárias / Lígia Márcia Martins, Newton Duarte (orgs.); apoio técnico Ana Carolina Galvão Marsiglia. - São Paulo : Cultura Acadêmica, 2010.

il.

Inclui bibliografia

ISBN 978-85-7983-103-4

1. Professores - Formação - Brasil. 2. Educação - Filosofia. 3. Educação Brasil. 4. Aprendizagem. I. Martins, Ligia Márcia, 1958-. II. Duarte, Newton, 1961 .

11-0103.

CDD: 370.71

CDU: $37.011 .3-051$

Este livro é publicado pelo Programa de Publicações Digitais da Pró-Reitoria de Pós-Graduação da Universidade Estadual Paulista "Júlio de Mesquita Filho" (UNESP)

Editora afiliada:

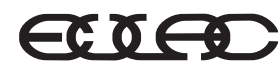

Asociación de Editoriales Universitarias de América Latina y el Caribe

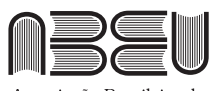

Associação Brasileira de Editoras Universitárias 


\section{SUMÁRIO}

Apresentação 7

1 O legado do século XX para a formação de professores 13 Lígia Márcia Martins

2 O debate contemporâneo das teorias pedagógicas 33 Newton Duarte

3 Construtivismo, pós-modernidade e decadência ideológica 51 José Luis Derisso

4 Os conceitos de atividade e necessidade para a Escola Nova e suas implicações para a formação de professores 63 Afonso Mancuso de Mesquita

5 Alienação e emancipação na transmissão do conhecimento escolar: um esboço preliminar 83 Mauro Sala

6 Relações entre o desenvolvimento infantil e o planejamento de ensino 99 Ana Carolina Galvão Marsiglia 
7 A arte e a formação humana: implicações para o ensino de literatura 121

Nathalia Botura de Paula Ferreira

8 O trabalho do professor e a alfabetização: uma análise dos ideários educacionais 139

Fatima Aparecida de Souza Francioli

9 O papel do professor e do ensino na Educação Infantil:

a perspectiva de Vigotski, Leontiev e Elkonin 161 Juliana Campregher Pasqualini 


\section{Apresentação}

Esta coletânea de textos produzidos por professores e alunos da linha de pesquisa Teorias Pedagógicas, Trabalho Educativo e Sociedade, do Programa de Pós-Graduação em Educação Escolar, da Universidade Estadual Paulista (Unesp), campus de Araraquara, traz uma contribuição original a um campo no qual muito tem sido publicado nas duas últimas décadas no Brasil, o da formação de professores.

A especificidade da coletânea reside na abordagem historicizante e crítica tanto das diretrizes oficiais para a formação de professores como das teorias pedagógicas e respectivas propostas metodológicas nesse terreno.

São nove textos, que vão desde um balanço crítico do legado deixado pelo século XX no que se refere à formação de professores até questões específicas relacionadas ao trabalho do professor, passando pela questão do debate contemporâneo sobre as teorias pedagógicas.

O público ao qual se destina esta coletânea são alunos de pedagogia e demais licenciaturas, alunos de mestrado e doutorado em educação, pesquisadores da área educacional e professores atuantes nos diversos níveis da educação escolar.

A coletânea inicia-se com o capítulo intitulado "O legado do século XX para a formação de professores”, de autoria de Lígia Már- 
cia Martins. A autora define como eixo de análise a relação entre a referida formação e a atividade produtiva, ou seja, a formação do professor na relação com o processo e produto de seu trabalho. Defende o argumento de que, lamentavelmente, um dos maiores legados do século XX para a formação de professores foi o acirramento de sua subserviência às demandas hegemônicas do capital. No âmbito educacional isso é letal, posto que o produto do trabalho educativo deve ser a humanização dos indivíduos, que, por sua vez, só pode ocorrer pela mediação da própria humanidade dos professores. Reitera a necessidade da crítica a essa situação, apontando o quanto ela ainda se faz presente, vide suas expressões no Documento de Referência para a Conferência Nacional de Educação, que se consubstanciará no Plano Nacional da Educação para o próximo decênio, posto o risco de que os ideários oriundos do século XX, que se colocam a serviço da referida subserviência, avancem século XXI afora, trazendo do século passado aquilo que ele gestou de pior para a educação escolar.

Essa problematização da formação de professores tem continuidade na discussão feita por Newton Duarte no Capítulo 2 sobre "O debate contemporâneo das teorias pedagógicas". Inicialmente são apresentadas algumas características comuns às teorias pedagógicas mais difundidas na atualidade, dentre as quais destaca: a incapacidade de se situarem numa perspectiva de superação da sociedade capitalista o idealismo, a negação da perspectiva da totalidade, o relativismo epistemológico e cultural, o utilitarismo como critério de validade do conhecimento, a supervalorização do conhecimento tácito e a descaracterização do trabalho do professor. Em seguida, o texto destaca algumas características específicas ao construtivismo, à pedagogia dos projetos, à pedagogia do professor reflexivo, à pedagogia das competências e à pedagogia multiculturalista. À luz dessa análise o autor defende a tese de que essas pedagogias centram-se na cotidianidade alienada da sociedade capitalista contemporânea e, portanto, a superação dessas pedagogias requer a distinção entre a prática cotidiana e outras esferas da prática social, imprescindível para o resgate da função social da escola e do trabalho docente. 
Nessa mesma perspectiva de análise crítica do pensamento pedagógico hegemônico e suas influências na formação de professores, temos os três capítulos seguintes desta coletânea.

O Capítulo 3, de autoria de José Luis Derisso, intitula-se "Construtivismo, pós-modernidade e decadência ideológica”. Ancorado na análise de Lukács sobre a "decadência ideológica", aponta a continuidade entre as primeiras manifestações desse processo em meados do século XIX com a chamada pós-modernidade. Com o objetivo de refletir sobre como a produção educacional do período da decadência interfere na educação escolar, induzindo a um esvaziamento de sua finalidade de ensinar, o autor coloca em foco as expressões da referida continuidade no desenvolvimento das chamadas pedagogias ativas do movimento Escola Nova, do construtivismo e da pedagogia das competências. Nessa direção, analisando o esvaziamento do sentido da educação escolar contemporâneo, demonstra as afiliações desses ideários à pós-modernidade, emblematicamente consubstanciadas no construtivismo.

O Capítulo 4, intitulado "Os conceitos de atividade e necessidade para a Escola Nova e suas implicações para a formação de professores", de Afonso Mancuso de Mesquita, reporta-nos às origens da "escola ativa" e suas principais características, com vista à análise dos conceitos de atividade e necessidade postulados pelos atores sociais do movimento escolanovista. A falta de perspectiva histórica e a naturalização presentes em tais conceitos, ao se desdobrarem nas concepções de ensino, aprendizagem e função da educação escolar, circunscrevem a formação de professores, dotando-a de uma característica muito precisa: a aquisição de conhecimentos não tem valor intrínseco, destarte o conhecimento sistematizado cede lugar a um suposto autoconhecimento. Tendo como referência tais proposições, o autor destaca as convergências do construtivismo à Escola Nova e a unidade que entre eles se estabelece para a afirmação da psicologização da formação de professores.

No Capítulo 5, "Alienação e emancipação na transmissão do conhecimento escolar: um esboço preliminar”, Mauro Sala coloca sob análise a contradição entre alienação e emancipação na trans- 
missão do conteúdo escolar presente na sociedade capitalista. Sem secundarizar a necessidade de transmissão dos referidos conteúdos, aborda a especificidade da educação escolar, qual seja, a socialização do conhecimento historicamente elaborado, em suas necessárias relações com a superação das contradições engendradas pela sociedade de classe; manifestas de diferentes formas na educação escolar; no que se incluem muitos dos conteúdos que visa transmitir. Assim, explicita a premência da análise crítica desses para que, de fato, possam se expressar como apropriação das forças essenciais humanas, isto é, como conteúdos humanizadores.

Os capítulos 6, 7, 8 e 9 fecham a coletânea com contribuições sobre questões específicas do universo do trabalho do professor, procurando colaborar para a busca de alternativas às concepções dominantes.

No Capítulo 6, intitulado "Relações entre o desenvolvimento infantil e o planejamento de ensino”, Ana Carolina Galvão Marsiglia analisa as concepções espontaneístas acerca do desenvolvimento humano, especialmente no referente à construção do conhecimento, demonstrando suas consequências negativas para a organização do trabalho docente, no que se inclui a proposição do currículo, o planejamento do ensino e o papel da escola no trato com os conteúdos escolares. Deixa evidente que tais concepções subsidiam uma formação de professores que prima pelo destaque da forma em detrimento do conteúdo, centrando-se na unilateralidade da prática docente. Contrapondo-se a isso, a autora demonstra, com base na psicologia histórico-cultural e na pedagogia histórico-crítica, o papel de inalienável da escola e do planejamento de ensino para a apropriação dos conhecimentos mais elaborados, imprescindíveis ao desenvolvimento das funções psíquicas superiores.

No Capítulo 7, intitulado "A arte e a formação humana: implicações para o ensino de literatura”, Nathalia Botura de Paula Ferreira aponta a necessidade de compreensão do elemento essencial e ativo que repousa na gênese histórica da arte, isto é, do trabalho social e das formas de consciência dele advindas; colocando em evidência duas questões fundamentais para o ensino da arte: a impossibilidade de sua 
compreensão como expressão de uma interioridade pura, subjetivista e a necessidade de seu reconhecimento como elemento constitutivo na realização da essência humana. Assim, a arte, na qualidade de objetivação humano-genérica, precisa ser disponibilizada às novas gerações para que, dela se apropriando, conquistem formas mais elevadas de sensibilidade e formação. A autora fornece-nos inúmeros elementos para a afirmação do ensino da arte, em seu interior a literatura, tendo em vista uma educação escolar emancipatória a ser realizada, também, por meio da vivência estético literária.

No Capítulo 8, "O trabalho do professor e a alfabetização: uma análise dos ideários educacionais”, Fátima Aparecida de Souza Francioli reporta-se à trajetória de implantação da teoria psicogenética da língua escrita que, ao longo dos últimos vinte anos, tem orientado o trabalho docente em nosso país. Especialmente no âmbito da alfabetização. Tomando como eixo de análise o deslocamento da ênfase dos processos de ensino para os processos de aprendizagem, característica nuclear do modelo construtivista, a autora destaca a secundarização do trabalho do professor, que vemos ampliar-se a passos largos na atualidade, e suas nefastas consequências para a escolarização dos indivíduos, dentre as quais a baixa qualidade da aprendizagem e a inexistência de erradicação do analfabetismo (para além do analfabetismo funcional) demonstradas de modo alarmante nos índices das inúmeras estratégias de avaliação oficial.

Por fim, no Capítulo 9, intitulado "O papel do professor e do ensino na Educação Infantil: a perspectiva de Vigotski, Leontiev e Elkonin”, Juliana Campregher Pasqualini demonstra, com base nos estudos desses três autores, a impropriedade do tratamento dispensado ao ensino na produção teórica dos autores representativos da pedagogia da infância. Evidenciando a relação entre o desenvolvimento infantil e a apropriação da cultura, conclui que o professor que atua junto à criança de 0 a 5 anos não pode ser definido apenas como aquele que estimula e acompanha o desenvolvimento infantil, mas como alguém a quem compete dirigir o processo educativo por meio do ensino. 
12 LÍGIA MÁRCIA MARTINS • NEWTON DUARTE

Espera-se com este livro provocar um amplo debate sobre alternativas voltadas para uma perspectiva distinta das que predominam na formação de professores no Brasil contemporâneo.

Lígia Márcia Martins Newton Duarte

Organizadores 


\section{1 \\ O LEGADO DO SÉCULO XX PARA A FORMAÇÃO DE PROFESSORES ${ }^{1}$}

Lígia Márcia Martins ${ }^{2}$

A formação de professores como objeto de estudo integra debates que vieram se ampliando no Brasil desde o final da década de 1970, assumindo maior dinamismo nas décadas de 1980 e 1990, em especial, a partir da implementação da Lei de Diretrizes e Bases da Educação Nacional (LDB), promulgada em 1996. Assim, tomarmos a análise dessa temática como tarefa já é, por que não dizer, um primeiro legado do século XX!

Muitas seriam as possibilidades para o tratamento da questão em pauta e, em face dessa amplitude; não obstante levarmos em conta a formação de professores como síntese de múltiplas determinações,

1 Texto originalmente elaborado tendo em vista participação em mesa-redonda intitulada "O legado do século XX para a formação de professores", integrante da programação do IX Encontro de Pesquisa em Educação da Região Sudeste (Anpedinha), realizado na Universidade Federal de São Carlos de 8 a 11 de julho de 2009.

2 Psicóloga, mestre em Psicologia Clínica pela Pontifícia Universidade Católica de São Paulo (PUC-SP), doutora em Educação pela Universidade Estadual Paulista (Unesp), campus de Marília. É professora do curso de graduação em Psicologia da Unesp, campus de Bauru, do Programa de Pós-Graduação em Educação Escolar da mesma universidade, campus de Araraquara, e membro do Grupo de Pesquisa "Estudos marxistas em educação". 
elegemos uma delas como eixo a partir do qual possamos analisar um dos legados do século XX.

O referido eixo de análise diz respeito à relação entre formação profissional e atividade produtiva, ou seja, a formação de dado trabalhador na relação com o produto de seu trabalho e com as condições histórico-sociais nas quais ocorre. Primeiramente, adiantamos que concebemos a formação de qualquer profissional, aqui em especial a de professores, como uma trajetória de formação de indivíduos, intencionalmente planejada, para a efetivação de determinada prática social.

Assim sendo, nenhuma formação pode ser analisada senão na complexa trama social da qual faz parte. Ao assumirmos a referida prática como objeto de análise, observando que não estamos nos referindo à "prática" de sujeitos isolados, mas à prática do conjunto dos homens num dado momento histórico, deparamos com uma tensão crucial: a contradição entre o dever ser da referida formação e as possibilidades concretas para sua efetivação. Portanto, a materialização do referido dever ser não pode prescindir da luta pela superação das condições que lhe impõem obstáculos.

Concordamos com o educador Antônio Joaquim Severino ao afirmar que a educação, como prática institucionalizada, isto é, como educação escolar, deva preparar os indivíduos para os domínios necessários ao tríplice universo que rege sua existência concreta. Nas palavras do autor:

Numa sociedade organizada, espera-se que a educação, como prática institucionalizada, contribua para a integração dos homens no tríplice universo das práticas que tecem sua existência histórica concreta: no universo do trabalho, âmbito da produção material e das relações econômicas; no universo da sociabilidade, âmbito das relações políticas; e no universo da cultura simbólica, âmbito da consciência pessoal, da subjetividade e das relações intencionais. (Severino, 2002, p.11)

Sob quais condições, todavia, se processa, na sociedade moderna, a formação profissional dos indivíduos? Seguramente não são as que 
contemplam o atendimento dos objetivos prescritos no excerto em destaque, mas, sim, sob condições que convertem de modo avassalador o trabalho; em seu sentido marxiano, filosófico, condição ontogenética de humanização; em emprego, isto é, em trabalho alienado, e que, em detrimento do pleno desenvolvimento dos indivíduos, encontra no vetor econômico o eixo nuclear de sua estruturação.

\section{Dilemas do trabalho educativo: entre a humanização e a alienação}

Sob a égide do modelo econômico social vigente não podemos preterir a análise dos condicionantes que se estabelecem entre a formação para determinado tipo de ocupação profissional (o ideal seria que pudéssemos dizer trabalho!) e as demandas hegemônicas dessa sociedade acerca de quais devam ser os produtos dessa ocupação, ou seja, os seus resultados. Consideramos que um dos legados do século XX para a formação de professores foi o acirramento dessa contradição.

No tocante à formação docente isso é letal, pois o produto do trabalho educativo deve ser a humanização dos indivíduos, que, por sua vez, para se efetivar, demanda a mediação da própria humanidade dos professores. Conforme destacamos em outro trabalho (Martins, 2007), o objetivo central da educação escolar reside na transformação das pessoas em direção a um ideal humano superior, na criação das forças vivas imprescindíveis à ação criadora, para que seja, de fato, transformadora, tanto dos próprios indivíduos quanto das condições objetivas que sustentam sua existência social.

Não estamos, portanto, nos referindo à concepção liberal de humanização, para quem esse processo se efetiva na centralidade do sujeito abstraído das circunstâncias concretas de sua existência. Trata-se, outrossim, de um processo dependente da produção e reprodução em cada indivíduo particular das máximas capacidades já conquistadas pelo gênero humano. Um processo, portanto, absolutamente condicionado pelas apropriações do patrimônio físico e 
simbólico produzido historicamente pelo trabalho dos homens, dos quais os professores não podem estar alienados.

Ao longo do século XX, os ideais humanizadores da educação escolar; ainda que nos limites da humanização burguesa propalada nos primórdios da educação escolar; esvaem-se pelos meandros de sucessivas formas e reformas pelas quais se ordenou a sociedade do capital. Em estreita sintonia com essa ordem se estruturaram e se firmaram, de modo orgânico, os ideários pedagógicos que hegemonicamente nortearam, e continuam norteando, tanto a prática docente quanto (e para tanto!), a formação de professores.

Ao aliarmos a formação de professores a projetos voltados à universalização da educação escolar, ainda que consubstanciados pelo objetivo de alfabetização, precisamos levar em conta que, em nosso país, esse ideal, como meta do Estado, inexistiu até a década de 1930. E mais, desde as suas origens, despontaram atrelados a um suposto modelo de "modernização" do país, que já pressupunha a instrução dos indivíduos para a produção e consumo como uma das condições requeridas à sua implementação.

Os "ventos modernizantes" que marcaram o início do século XX criaram o fértil terreno para as renovações sociais e, dentre elas, no campo educacional, o advento da pedagogia nova. E quais foram os rumos trilhados de lá para cá que e que prescreveram a formação de professores? Para responder a essa questão recorro aos marcos referenciais do século XX apresentados na periodização das ideias pedagógicas no Brasil, elaborada por Dermeval Saviani (2007) em seu livro História das ideias pedagógicas no Brasil. ${ }^{3}$

Segundo esse autor, o século passado foi cenário, em suas três primeiras décadas, da coexistência entre as vertentes religiosas e leigas da pedagogia tradicional, com predomínio das segundas. Tais décadas foram profundamente marcadas pelo debate das ideias liberais

3 Ao tomarmos a referida periodização como referência, o fazemos a título de elucidação geral do transcurso do século XX, pois a apresentação pormenorizada da profunda análise do autor acerca disso ultrapassa os objetivos e limites deste texto. 
que, em seu bojo, advogava a universalização da educação escolar sob ação do Estado e a apologia do seu papel na superação da ignorância dos indivíduos com vista à sua conversão em cidadãos esclarecidos. Foi também, o contexto social dos primeiros sinais de declínio da versão tradicional da pedagogia liberal em direção à sua expressão moderna. Encontrava-se em curso a preparação político-pedagógica das condições para a implementação da pedagogia nova.

Entre 1932 e 1947, a pedagogia tradicional e a pedagogia nova orquestraram, equilibradamente, a educação no país; equilíbrio, porém, superado entre 1947 e 1961, quando as influências da pedagogia nova tornaram-se predominantes. Não obstante, a mesma década (1960) que marcou o seu auge, marcou também o seu declínio. Profundas mudanças sociais que se faziam presentes (a exemplo da industrialização/modernização do país, aceleração da urbanização e reivindicações pela democratização da escola pública, influências da "guerra fria" etc.) gestaram os primeiros sinais de esgotamento do ideário que fora aventado como ícone de uma educação moderna, democrática e humanista.

Ao final das décadas de 1960 e 1970, quando ao modelo taylorista-fordista se contrapõem novos parâmetros de organização e gerenciamento do sistema produtivo, quando a ordem social subjuga-se de modo absoluto aos ditames da acumulação flexível, as demandas pela formação do indivíduo apto a adequar-se a esses novos tempos, obviamente, recaem sobre a educação escolar. No esteio da reestruturação do capital em curso, as ideias da "teoria do capital humano" tornavam-se palavras de ordem. A formação da mão de obra tecnicamente adequada ao perfil dos novos postos de trabalho subjugava, a passos largos, a educação escolar, tanto na prescrição de seus conteúdos, cada vez mais pragmáticos, quanto na prescrição dos seus métodos e técnicas de ensino, cada vez mais enfatizados.

Nas décadas subsequentes e até o final do século XX, verifica-se a ascensão da concepção pedagógica produtivista, no bojo da qual despontam, simultaneamente, o acirramento das concepções tecnicistas e as análises crítico filosóficas acerca dos limites/possibilidades da educação escolar na sociedade do capital, à luz das quais se desen- 
volve a visão "crítico reprodutivista”. Mas, também a esse tempo, se anunciam ideários contra-hegemônicos, a exemplo das orientações pedagógicas para uma "educação popular", da pedagogia crítico-social dos conteúdos e da pedagogia histórico-crítica. Tais forças, ainda que nos limites de suas expressões contra-hegemônicas, não deixaram de subsidiar importantes debates no campo educacional e na sociedade civil organizada, expressos em avanços na Constituição de 1986 em relação à educação no país.

No “apagar das luzes” do século XX (1991-2001), constata-se o recrudescimento de ideários pedagógicos cada vez mais alinhados às demandas das contínuas estruturações e reestruturação do capital, sintetizados pelo que o autor denomina "neoprodutivismo" e suas vertentes, quais sejam, o "neoescolanovismo", expresso nas pedagogias do "aprender a aprender", o "neoconstrutivismo", expresso na individualização da aprendizagem e na "pedagogia das competências", e o "neotecnicismo", expresso em princípios de administração e gestão da escola cada vez mais alinhados às normativas empresariais, a exemplo dos programas de "qualidade total", cumprimento de metas quantitativistas, sistemáticas de avaliação do produto em detrimento do processo etc.

Enfim, do escolanovismo ao neoescolanovismo, do tecnicismo ao neotecnicismo, do construtivismo ao neoconstrutivismo "vencemos" o século XX (ou fomos por ele vencidos!) acompanhando a vitória da lógica mercantil no campo da educação, que cada vez mais se vê orquestrado pelos organismos internacionais (Unesco, Unicef, Banco Mundial e FMI etc.), cujas palavras de ordem foram e continuam sendo: qualidade, produtividade e equidade com a máxima racionalização e otimização dos recursos já existentes (Saviani, 2000).

Nessa mesma direção, Roberto Leher (1999, p.19 e 20), em análise da política educacional imposta por tais organismos, afirma que, por mais paradoxal que possa parecer, o Banco Mundial se converte no "Ministério Mundial da Educação" para os países periféricos, consagrando "a dimensão estritamente instrumental da educação em face da nova dinâmica do capital”. Destaca, ainda, o acelerado recuo dos países que no início da década de 1980 resistiram ao in- 
tervencionismo e à imposição do neoliberalismo, que culminou na mais absoluta submissão desses países às imposições dos "Senhores da Educação", mentores e implementadores das diretrizes do Consenso de Washington.

E no âmbito específico da formação de professores, qual é o saldo dessa história? Como nunca, a importância da formação inicial e contínua desse profissional é conclamada e, como nunca, também, tão esvaziada de sua função precípua, qual seja, a formação de pessoas aptas aos domínios do tríplice universo anteriormente referido.

Nela, o "saber fazer" passa a se sobrepor a qualquer outra forma de saber, apresentando-se travestido, também, sob a forma de "competência". Competência... baseada no critério da lucratividade e da sociabilidade adaptativa, equidistante, portanto, de critérios sociais éticos e humanos. Cabe dizer, mesmo, que essa sobreposição apresenta-se com uma roupagem progressista e sedutora, como bem analisam Silva Jr. \& Cammarano Gonzáles (2001).

Tais autores, destacando os vínculos entre as reformas educacionais impostas ao final do século XX, a construção de competências e a prática social, colocam em questão a dupla face do modelo educacional presente nas diretrizes educacionais em curso no nosso país: se, por um lado, esse modelo exige a construção do conhecimento por meio de uma prática social, dado potencialmente positivo, por outro, pretere a "base valorativa dessa prática social, que no momento atual, constitui-se predominantemente dos valores econômicos do mercado" (Silva Jr. \& Cammarano Gonzáles, 2001, p.32).

Nessa direção, ao destacarem a positividade explícita e a negatividade oculta desse modelo, os autores afirmam a necessária negação da base valorativa sobre a qual se encontra alicerçada a sociedade contemporânea e a formação de seus membros, a determinar "a produção de um modelo de competência às avessas” (ibidem, p.33).

Um modelo, portanto, que se contraponha ao tipo de saber que assume a forma "valor" e que é vendido e consumido como qualquer outra mercadoria. A ser consumido, até mesmo, sob o emblemático slogan do "aprender a aprender", quiçá próprio de quem nunca pode aprender efetivamente, isto é, que não possibilitou aos indivíduos 
a conquista da própria autonomia intelectual. E que, igualmente, se contraponha à formação de indivíduos centrada nos ideais de eficácia e otimização das performances, voltada para o desempenho pragmático e quantificável.

Em suma, urge a proposição de um modelo de formação alternativo, no qual a construção de conhecimentos se coloque a serviço do desvelamento da prática social, apto a promover o questionamento da realidade fetichizada e alienada que se impõe aos indivíduos. Que supere, em definitivo, os princípios que na atualidade têm norteado a formação escolar, em especial a formação de professores.

Sem a pretensão de esgotar a análise de tais princípios em toda a sua abrangência, mas visando à síntese de suas expressões no âmbito da formação de professores, vejamos suas manifestações mais expressivas no que se referem ao papel da teoria (entenda-se, dos conhecimentos universais, historicamente sistematizados); às funções da educação escolar, bem como em suas vinculações a um pretenso "novo tempo", a ser inaugurado pelo terceiro milênio.

\section{Formação de professores: para quê?}

Um primeiro princípio que tem norteado a formação de professores, a se colocar em tela neste texto, diz respeito ao descarte da teoria, da objetividade e da racionalidade expresso na desqualificação dos conhecimentos clássicos, universais, e em concepções negativas sobre $o$ ato de ensinar, como claramente analisam Moraes (2001) e Duarte (1998), respectivamente. Esses autores, dedicando-se à análise do esvaziamento teórico presente na educação escolar em seus diferentes níveis e formas de organização, convergem na afirmação do irracionalismo como marca da "contemporaneidade pós-moderna", à luz do qual a construção do conhecimento como forma de decodificação do real, isto é, sua identificação à inteligibilidade da realidade em sua universalidade e concretude passa a ser cada vez mais negada.

O lugar outrora ocupado pela metanarrativa, isto é, por uma teorização objetiva, geral e universal da história, passa a ser ocupa- 
do pelas descrições fenomênicas e pelas interpretações consensuais presentes em representações mentais primárias (locais, imediatas e fortuitas) com as quais a realidade passa a ser identificada. Ora, no esteio de tal "paradigma", o que há de se ensinar na escola? Pela via da desqualificação do saber historicamente sistematizado; conteúdo por excelência do ato de ensinar; nega-se o próprio ato.

A referida negação, todavia, não se instala sem argumentos a seu favor! Dentre tais argumentos, destaque-se a defesa da particularização e individualização do ensino como expressão de respeito às singularidades do aluno, tanto em relação às suas possibilidades cognitivas quanto em relação à sua pertença cultural.

Os conhecimentos sincréticos, empíricos, fortuitos, heterogêneos e de senso comum substituem a sistematização de relações explicativas causais já conquistadas pela humanidade e, assim, (re)significa-se a realidade, identificada, então, com o compartilhamento de interpretações. Delega-se, sobretudo, à "sabedoria de vida" o papel de orientar o sujeito no mundo, identificado minimamente com a vida cotidiana e com intensas e rápidas transformações.

Em nome dessas transformações, caberá à educação escolar preparar os indivíduos para o seu enfrentamento! Diante de um mundo em "constantes transformações", mais importante que adquirir conhecimentos, posto sua "transitoriedade", será o desenvolvimento de competências para o enfrentamento dessas. Apela-se, pois, à formação de personalidades flexíveis, criativas, autônomas, que saibam trabalhar em grupos e comunicar-se habilmente e, sobretudo, estejam aptas para os domínios da "complexidade do mundo real".

Tendo em vista essa "preparação", a resolução de problemas erige-se como exigência básica da educação escolar, de tal forma que a aprendizagem baseada em problemas se converte na estratégia azada para a formação de indivíduos "participativos". Caberá à escolarização oportunizar os meios pelos quais o aluno se coloque como sujeito de sua aprendizagem, entendendo-se que, assim, consequentemente, ocupará seu lugar na sociedade de modo "crítico" e "cidadão".

Aliando-se a esses objetivos, a ênfase recai nas aprendizagens que o aluno realiza a partir de si mesmo, no respeito às suas necessidades 
e motivações e nos limites daquilo que identifica como problema a partir de um diálogo com o seu contexto. Identifica-se, pois, a formação escolar com o desenvolvimento da capacidade para resolver problemas.

Todas essas premissas ancoram-se, direta ou indiretamente, na tese emblemática segundo a qual o terceiro milênio transcorrerá à luz de um novo paradigma, delineador de um quadro epistêmico que requer a transformação da relação Sujeito/Objeto em relação Eu/Tu, o princípio da causalidade em finalismo, o conhecimento em autoconhecimento, tal como sinalizado por Boaventura Santos (1988).

$\mathrm{O}$ autor supracitado considera que o paradigma científico emergente - entenda-se, pós-moderno - assenta-se na necessidade inadiável de se reconhecer a relação sujeito/objeto na qual um é continuação do outro e, assim sendo, todo conhecimento se revela, também, como autoconhecimento. Nas palavras do autor: "Os pressupostos metafísicos, os sistemas de crenças, os juízos de valor não estão nem antes nem depois da explicação científica da natureza ou da sociedade. São partes integrantes dessa mesma explicação" (ibidem, p.67).

No esteio dessas prerrogativas, tornou-se cada vez mais recorrente, ao longo do século XX, o apelo à necessidade de se recriar tanto $\mathrm{a}$ escola quanto a formação de professores. Para essa "nova formação", os destaques centrais recaíram sobre a trajetória de construção da identidade pessoal-profissional, primando pelo objetivo da promoção da "reflexão" e, preferencialmente, da "reflexão crítica" acerca da própria prática.

Consequentemente, a linha distintiva entre a escola como lócus do exercício profissional e a escola como lócus que deva preparar filosófica, teórica e metodologicamente o professor para esse exercício vai se diluindo de modo cada vez mais rápido e mais cedo na formação inicial do professor. As dimensões técnicas da prática de ensino passam a ocupar um lugar central, em detrimento de seus próprios fundamentos. Privilegia-se a forma mutilada de conteúdo!

Essa diluição, todavia, também ocorre sob um forte argumento, qual seja, a necessária articulação entre teoria e prática. Uma articulação, porém, centrada na resolução de problemas práticos imediatos 
e o manejo das situações concretas do cotidiano escolar, enfim, que privilegia a forma em detrimento do conteúdo, deixando implícita a falaciosa frase: "na prática a teoria é outra"!

Por esse caminho vemos a formação de professores, seja ela inicial ou contínua, aligeirar-se a passos largos, tornando-se presa fácil para os empresários da educação e para os administradores de universidades públicas que, em nome de uma justa e correta necessidade de formação de professores em nosso país, dentre outras mazelas, justificam a formação inicial de professores via Ensino a Distância (EaD).

Em suma, indubitavelmente a formação de professores tem sido reconhecida, na atualidade, como merecedora de grande atenção e análise, se revela no entanto diretamente proporcional ao seu esvaziamento. O destaque a ela conferido, cada vez mais centrado em premissas que visam o "pensamento reflexivo", a particularização da aprendizagem, a forma em detrimento do conteúdo, o local em detrimento do universal, dentre outras, não é representativo daquilo que de fato deva ser a assunção dos elementos fundamentais requeridos a uma sólida formação de professores, no que se inclui, em especial, a apropriação do patrimônio intelectual da humanidade.

\section{Finalizando...}

Penso que para se identificar o legado de um passado, nada melhor do que um olhar sobre o que se anuncia para o futuro. Nessa direção recorro, a título de uma breve ilustração dos legados do século XX para a formação de professores, ao disposto no Documento de Referência para a Conferência Nacional de Educação (Conae ${ }^{4}$ (Brasil, 2009), realizada em abril de 2010. Lembramos que, neste texto, não temos como objetivo a análise completa e pormenorizada do documento, todavia recorremos a ele para exemplificar, ainda

4 Tomamos como base o Documento de Referência para a Conferência Nacional de Educação, posto que até o momento da elaboração deste texto o Relatório Oficial resultante da referida Conferência não havia sido publicado. 
que parcialmente, aquilo que se anuncia para a educação escolar do próximo decênio.

O tema central do referido Documento é a construção do Sistema Nacional Articulado de Educação: o Plano Nacional de Educação, Diretrizes e Estratégias de Ação, e encontra-se organizado em torno de seis eixos, a saber: "Papel do Estado na garantia do direito à educação de qualidade”; "Qualidade da educação, gestão democrática e avaliação"; "Democratização do acesso, permanência e sucesso escolar"; "Formação e valorização dos profissionais de educação"; "Financiamento da educação e controle social"; "Justiça social, educação e trabalho: inclusão, diversidade e igualdade".

Sua elaboração esteve a cargo da Comissão Nacional Organizadora da Conae, instituída conforme Portaria Ministerial n.10, publicada em 3 de setembro de 2008, a quem competiu a proposição e coordenação do processo que, em âmbito nacional, antecedeu a realização da Conferência Nacional de Educação, cujos resultados serão consubstanciados no Plano Nacional de Educação para o próximo decênio.

O Documento de Referência em questão foi objeto de estudos e deliberações em Conferências Municipais ou Intermunicipais, que ocorreram no primeiro semestre de 2009, e de Conferências Estaduais e do Distrito Federal, realizadas no segundo semestre do mesmo ano. Em face dos objetivos do presente texto, tomamos como dados para a ilustração dos referidos legados excertos do Eixo IV, que trata especificamente da "Formação e valorização dos profissionais da educação".

A primeira consideração que julgamos digna de nota refere-se à explicação acerca da adoção da expressão Profissionais da educação.

O termo trabalhadores da educação se constitui como recorte de uma categoria teórica que retrata uma classe social: a dos trabalhadores. Assim, refere-se ao conjunto de todos os trabalhadores que atuam no campo da educação.

Sob outro ângulo de análise [...] surge o termo profissionais da educação, que são, em última instância, trabalhadores da educação, 
mas que não obrigatoriamente se sustentam na perspectiva teórica de classes sociais.

Portanto, dada a maior disseminação do segundo termo, o presente documento usará o de profissionais da educação... (Brasil, 2009, p.59, grifos nossos)

O excerto em questão, introdutório ao Eixo IV, anuncia, sem maiores delongas, um claro posicionamento ideológico: a negação de considerações analíticas acerca de uma sociedade que, não obstante as tentativas de mascaramento, continua sendo uma sociedade de classes. Ora, não necessitamos de grandes esforços para reconhecer que a perspectiva teórica de classes sociais de menor disseminação em questão é o marxismo.

Proposições dessa natureza são encontradas recorrentemente entre teóricos que advogam os "novos tempos" da pós-modernidade que, ao negarem as explicações objetivas e totalizantes acerca da história, negam também qualquer projeto de superação da sociedade do capital.

Conforme analisamos em momento anterior deste texto, o desprezo contemporâneo às metanarrativas, no que se incluem as análises acerca da propriedade privada dos modos de produção e da alienação que dela decorre, traz em seu bojo todos os riscos de um irracionalismo que se contrapõe à verdade, à ciência e à ação humana capaz de nortear os rumos da história.

Não obstante, em outro excerto encontramos a seguinte consideração:

A fim de contribuir para uma educação básica e superior de qualidade, uma política nacional de formação dos profissionais da educação garantirá a formação baseada na dialética entre teoria e prática, valorizando a prática profissional como momento de construção e ampliação do conhecimento, por meio da reflexão, análise e problematização do conhecimento e das soluções criadas no ato pedagógico. (ibidem, p.61, grifos nossos) 
Causa-nos no mínimo estranheza uma concepção que, ao afirmar-se dialética, privilegia um dos polos da relação! Tal consideração fere por si mesma a propriedade conceitual que aparentemente visa expressar. Primeiramente, porque a dicotomia teoria versus prática, outra coisa não é senão expressão da alienação entre trabalho intelectual e trabalho material instalada pelas relações sociais de produção próprias à sociedade burguesa. Assim, sua real superação não ocorrerá à margem da crítica radical a essa forma de organização social, dado que nos parece abandonado pelos proponentes do Documento, a exemplo do disposto no excerto anteriormente destacado.

A afirmação da dialeticidade entre teoria e prática demanda a compreensão acerca do que seja oposição e contradição. No âmbito do pensamento dialético os opostos não são confrontados exteriormente. Diferentemente, são reconhecidos como interiores um ao outro, no que reside um dos mais importantes princípios da lógica dialética, denominado identidade dos contrários (Kopnin, 1978). Em conformidade com esse princípio, afirma-se a unidade indissolúvel entre os opostos, e isso demanda reconhecer a essencialidade prática de toda e qualquer teoria, bem como a essencialidade teórica de toda e qualquer prática.

Ancorado num equívoco conceitual, o excerto em questão revela-se vazio, ou pior, um sutil disfarce para a manutenção das estratégias de defesa dos ideários representativos do "professor crítico-reflexivo”, que, tal como analisado por Duarte (2000), integram a ideologia do "aprender a aprender". Para esse autor, tais ideários expressam proposições educacionais a serviço do projeto neoliberal "considerado projeto político de adequação das estruturas e instituições sociais às características do processo de reprodução do capital no final do século XX" (ibidem, p.3).

Nossa dedução, na direção do reconhecimento de expressões do "aprender a aprender" consubstanciadas no Documento de Referência, não nos parece injustificada, especialmente se analisamos o disposto na sequência: "essa política deve propiciar o desenvolvimento da capacidade de reflexão, oferecendo perspectivas teóricas de análise da prática, para que os profissionais nela se situem e compreendam, 
também, os contextos históricos, sociais, culturais e organizacionais em que atuam" (Brasil, 2009, p.61-2).

Em momento anterior deste texto, sinalizamos a ênfase conferida a uma suposta necessidade de se "recriar a escola e a formação de professores". Foi no esteio dessa prerrogativa que despontou a teoria do professor reflexivo, de ampla projeção em nosso país desde a década de 1990. A formação reflexiva de professores tem na "prática" docente o critério de referência em torno do qual o professor, em formação inicial ou contínua, deva construir conhecimentos, problematizar o trabalho docente e buscar as alternativas necessárias à melhoria da educação escolar.

Não obstante tais ideais, uma análise radical das proposições presentes na referida teoria, a exemplo da análise realizada por Facci (2004), em sua obra Valorização ou esvaziamento do trabalho do professor? Um estudo crítico comparativo da teoria do professor reflexivo, do construtivismo e da psicologia vigotskiana, evidencia as fragilidades dela resultantes.

Concebendo a formação como um processo que a pessoa, em formação, realiza sobre si mesma e o conhecimento, como instrumento para a resolução de problemas práticos imediatos, esse modelo visa à elaboração de ações adequadas aos contextos e às próprias possibilidades nele existentes, o que, em última instância, significa preparar os indivíduos para a plena adaptação às circunstâncias sem debruçar-se sobre a real compreensão de seus determinantes. Por essa via, ratifica-se a cotidianidade, o "recuo da teoria" e a empiria no âmbito da educação escolar, dados que ampliam sobremaneira os limites a uma formação escolar verdadeiramente emancipatória.

Nessa mesma direção, são encontradas outras proposições no Documento em questão, a exemplo da defesa de "uma política nacional de formação e valorização dos profissionais do magistério, pautada pela concepção de educação como processo construtivo e permanente [que assegure, dentre outros, a] implementação de processos que visem à consolidação da identidade dos professores" (Brasil, 2009, p.63, grifos no original). 
A associação entre valorização do professor e trajetória identitária integra discursos que muito têm em comum com os ideários do "aprender a aprender" que, particularizando os processos formativos, conferem grande destaque às vivências pessoais e profissionais, à história de vida, à construção da identidade etc.

Conforme afirmamos em outro trabalho (Martins, 2007), não consideraríamos esse destaque problemático se a ele não se vinculassem, além da localização no indivíduo daquilo que não depende dele tomado particularmente, severas críticas à escolarização que visa à apropriação dos conhecimentos objetivos, considerada representativa de uma "racionalidade técnica" que "pretere a formação pessoal" e de uma "objetividade" que pretere a "subjetividade", máximas que corroboram para a ascensão de "considerações negativas sobre o ato de ensinar” (Duarte, 1998, p.86).

Consideramos, ainda, que uma efetiva valorização docente, aliada à construção da identidade dos professores, não se constrói em detrimento dos significados e sentidos conferidos à natureza da atividade que realizam, da qual resulta, até mesmo, o reconhecimento material pelo trabalho desenvolvido. A referida valorização, portanto, demanda reconhecer a formação e o trabalho do professor em toda a sua complexidade como, fundamentalmente, condição para a plena humanização dos indivíduos, sejam eles alunos, sejam professores.

Para que isso ocorra, é imprescindível o desenvolvimento das capacidades que são requisitadas e mobilizadas por aquilo que identifica a profissionalidade do professor, ou a essência concreta de sua prática social. Tratando-se da atividade docente, muitas são essas capacidades, mas, dentre elas, destacamos especialmente uma, posto considerá-la condicionante das demais, qual seja, a capacidade para ensinar.

A valorização do ensino, todavia, também demanda outras adjetivações. A qual ensino, então, nos referimos? Àquele que possa representar acréscimos de valor na direção da "emancipação humana das condições de exploração em que vive a grande maioria dos indivíduos, nas quais se incluem, muitas vezes, os próprios professores" (Martins, 2009, p.470). Destarte, não consideramos sinônimo de 
intenção valorativa, estratégias incertas e duvidosas pelas quais os professores possam ser formados, a exemplo da modalidade de Ensino a Distância (EaD), anunciada como "possibilidade" no Documento em tela.

Parece adequado pensar que toda formação inicial deverá preferencialmente se dar de forma presencial, inclusive aquela destinada aos professores leigos que atuam nos anos finais do ensino fundamental e no ensino médio, quanto aos professores de educação infantil e anos iniciais do fundamental em exercício, possuidores de formação em nível médio. Assim, a formação inicial pode, de forma excepcional, ocorrer na modalidade de EaD para os profissionais em exercício, onde não existam cursos presenciais. (Brasil, 2009, p.656 , grifos nossos)

Não nos "parece adequado" que a formação inicial do professor deva ser presencial! Temos certeza! Tal afirmação, reconhecidamente categórica, não resulta de nenhum tipo de preconceito em relação às novas tecnologias de informação e comunicação, mas sim da defesa de uma sólida formação a esse profissional, solidez que é requerida pela complexidade das tarefas que o aguardam em sua atuação profissional.

Por sua vez, a "flexibilização" representada pela modalidade EaD nos convida a um apelo por coerência no próprio discurso educacional hegemônico. Ora, se a "prática" é critério de referência para a formação do professor, como pensá-la externa à escola e à própria sala de aula? Nessa direção, nem mesmo os adeptos das teorias do "aprender a aprender" deveriam advogar a seu favor, dado que, lamentavelmente, não vem ocorrendo.

Ao levarmos em conta a argumentação segundo a qual a formação inicial via EaD deva ocorrer apenas em caráter "excepcional”, bem como para as situações nas quais "não existam cursos presenciais", somos levados, também, a uma contra-argumentação: tais condições não são naturais, não existem por acaso, mas atendem a uma ordem de fatores econômicos e sociais e a claros interesses de classe, no que 
se inclui o vasto filão de mercado que se abre para os empresários da educação.

Em suma:

Penso, portanto, que se não partirmos para um plano de emergência lúcido, corajoso, arrojado, que sinalize o empenho efetivo em reverter a situação de calamidade pública em que se encontra o ensino dos diferentes graus em nosso país, as proclamações em favor da educação não passarão de palavras ocas, acobertadoras da falta de vontade política para enfrentar o problema. E, nesse diapasão, avançaremos século XXI adentro, ampliando ainda mais o já insuportável déficit histórico que vem vitimizando a população brasileira em matéria de educação. (Saviani, 2000, p.32)

Diante do exposto, esperamos ter demonstrado alguns dos indicadores pelos quais, lamentavelmente, analisamos o legado do século XX para a formação de professores.

\section{Referências bibliográficas}

BRASIL, Presidência da República, Ministério da Educação: Secretaria Executiva e Secretaria Executiva Adjunta. Conferência Nacional de Educação 2010 - Conae - Construindo o Sistema Nacional Articulado de Educação - Documento de Referência, Brasília, MEC, 2009.

DUARTE, N. Concepções afirmativas e negativas sobre o ato de ensinar. Cadernos CEDES, Campinas, n.44, p.85-106, 1998.

Vigotski e o "aprender a aprender": crítica às apropriações neoliberais e pós-modernas da teoria vigotskiana. Campinas: Autores Associados, 2000.

FACCI, M. G. D. Valorização ou esvaziamento do trabalho do professor? Um estudo crítico comparativo da teoria do professor reflexivo, do construtivismo e da psicologia vigotskiana. Campinas: Autores Associados, 2004.

KOPNIN, P. V. A dialética como lógica e teoria do conhecimento. Rio de Janeiro: Civilização Brasileira, 1978.

LEHER, R. Um novo senhor da educação? A política educacional do Banco Mundial para a periferia do capitalismo. 1999. p.19-37. Disponível 
em: <http://www.revistaoutubro.com.br/edicoes/03/out3_03.pdf>. Acesso em: 3 jul. 2009.

MARTINS, L. M. A formação social da personalidade do professor: um enfoque vigotskiano. Campinas: Autores Associados, 2007.

Formação de professores: desafios contemporâneos e alternativas necessárias. In: MENDONÇA, S. G. L.; SILVA, V. P.; MILLER, S. Marx, Gramsci e Vigotski: aproximações. Araraquara: Junqueira \& Marin; São Paulo: Cultura Acadêmica, 2009.

MORAES, M. C. M. Recuo da teoria: dilemas na pesquisa em Educação. Revista Portuguesa de Educação, Braga, v.14, n.1, p.7-25, 2001.

SANTOS, B. S. Um discurso sobre as ciências na transição para uma ciência pós-moderna. Estudos Avançados, São Paulo, v.2, p.56-71, 1988.

SAVIANI, D. Educação brasileira: estrutura e sistema. Campinas: Autores Associados, 2000.

História das idéias pedagógicas no Brasil. Campinas: Autores Associados, 2007.

SEVERINO, A. J. Competência técnica e sensibilidade ético-política: o desafio da formação de professores. Cadernos FEDEP (Fórum Estadual de Defesa da Escola Pública), São Paulo, n.1, p.10-23, fevereiro de 2002. SILVA JUNIOR, J. dos R.; CAMMARANO GONZÁLES, J. L. Reformas educacionais, competências e prática social. São Paulo, Relatório de Pesquisa, Fundação de Amparo à Pesquisa do Estado de São Paulo (Fapesp), 2001. 



\section{2 \\ O DEBATE CONTEMPORÂNEO DAS TEORIAS PEDAGÓGICAS}

Newton Duarte ${ }^{1}$

Nas duas últimas décadas, o debate educacional tem se caracterizado por uma quase total hegemonia das "pedagogias do aprender a aprender" (Duarte, 2001), com destaque para o construtivismo, a pedagogia do professor reflexivo, a pedagogia das competências, a pedagogia dos projetos e a pedagogia multiculturalista.

A despeito das especificidades de cada uma, elas apresentam uma mesma tônica: a negação daquilo que chamam "educação tradicional". Elas podem ser consideradas pedagogias negativas, na medida em que aquilo que melhor as define é sua negação das formas clássicas de educação escolar. Essa atitude negativa em relação à escola, seus métodos, suas práticas e seus conteúdos clássicos não é um fenômeno exclusivo do final do século XX e início do século atual. Ela remonta ao movimento escolanovista do início do século passado e, recuando mais no tempo, a Pestalozzi e Froebel (Arce, 2002) que, na primeira

1 Pedagogo e mestre em Educação pela Universidade Federal de São Carlos (UFSCar), doutor em Educação pela Universidade Estadual de Campinas (Unicamp), realizou pós-doutorado na Universidade de Toronto (Canadá). É docente do Programa de Pós-Graduação em Educação Escolar da Universidade Estadual Paulista (Unesp), campus de Araraquara, e professor titular do Departamento de Psicologia da mesma instituição, além de líder do Grupo de Pesquisa "Estudos marxistas em educação". 
metade do século XIX, tentaram colocar em prática as ideias educacionais rousseaunianas. Essa filiação das pedagogias atualmente hegemônicas aos ideais escolanovistas não deve ser vista, entretanto, como um indicador de anacronismo dessas. Elas estão inteiramente em sintonia com o universo ideológico contemporâneo. As ideias defendidas por essas pedagogias, mesmo quando têm mais de um século de existência, assumem novos sentidos dados especialmente pelo contexto ideológico no qual predomina uma visão de mundo pós-moderna acrescida de elementos neoliberais quase nunca admitidos como tal. Nesse sentido, Saviani (2007) emprega o termo neoescolanovismo com referência ao significado do lema aprender a aprender na última década do século XX.

Considerando-se que não seria possível, no espaço deste capítulo, apresentar uma análise detalhada desse eclético caldo ideológico do qual se nutrem as pedagogias contemporâneas, abordarei na primeira seção do texto apenas algumas ideias ou princípios por elas compartilhados, para, na segunda, descrever brevemente as principais características específicas a cada uma dessas pedagogias. Por fim, na terceira seção, tecerei algumas considerações sobre um possível caminho de superação do enfoque pragmático da educação escolar preconizado por essas teorias pedagógicas.

\section{As ideias comuns às pedagogias hegemônicas na atualidade}

Um primeiro aspecto comum a essas pedagogias é a ausência da perspectiva de superação da sociedade capitalista, o qual está associado a uma concepção idealista das relações entre educação e sociedade. Ainda que, em trabalhos de alguns defensores dessas pedagogias, existam momentos de crítica a certos aspectos da sociedade capitalista, como às políticas neoliberais em educação, tais críticas acabam sendo neutralizadas pela crença na possibilidade de resolução dos problemas sociais sem a superação radical da atual forma de organização da sociedade, a qual tem como centro dinâmico a lógica 
de reprodução do capital. Como, porém, os problemas sociais mostram-se cada vez mais agudos, a solução ilusória à qual aderem essas pedagogias é a da visão idealista de educação. O adjetivo "idealista" é usado aqui não com referência à adesão a ideais, mas com referência ao princípio segundo o qual os problemas sociais são resultados de mentalidades errôneas, acarretando a crença de que a difusão pela educação de novas ideias entre os indivíduos, especialmente os das novas gerações, levaria à superação daqueles problemas. Por exemplo, a violência crescente na contemporaneidade poderia ser combatida por uma educação para a paz. A destruição ambiental poderia ser revertida por programas de educação ambiental. O desemprego poderia ser superado por uma formação profissional adequada às, supostamente, novas demandas do mercado de trabalho ou pela difusão da ideologia do empreendedorismo. Esse idealismo chega ao extremo de acreditar ser possível formar, no mesmo processo educativo, indivíduos preparados para enfrentar a competitividade do mercado e imbuídos do espírito de solidariedade social.

Associada a esse aprisionamento das pedagogias contemporâneas à lógica da sociedade capitalista e seu correspondente idealismo está uma ideia muito difundida, mas poucas vezes explicitada de forma clara. Trata-se da negação da perspectiva de totalidade, ou seja, da afirmação do princípio de que a realidade humana seria constituída de fragmentos que se unem não por relações determinadas pela essência da totalidade social, mas sim por acontecimentos casuais, fortuitos e inacessíveis ao conhecimento racional. Segundo essa perspectiva, seriam os acasos da vida de cada sujeito que determinariam o que é ou não relevante para sua formação.

Dessa negação da totalidade decorre um dos princípios centrais das pedagogias contemporâneas: o relativismo. Em primeiro lugar, trata-se de um relativismo epistemológico: o conhecimento seria sempre dependente do ponto de referência espacial e temporal a partir do qual o sujeito procura compreender os fenômenos naturais e sociais. Segundo esse princípio relativista, se o ato de conhecer depende das particularidades do ponto de referência no qual se situa o sujeito cognoscente e se é impossível situar-se para além dessas 
particularidades, então estariam inevitavelmente comprometidas a universalidade e a objetividade do conhecimento. Em segundo lugar, trata-se de um relativismo cultural. O mundo humano seria constituído por uma infinidade de culturas, cada qual com seus valores, suas práticas, suas crenças e concepções sobre a natureza e a sociedade. Nenhum conhecimento poderia ser considerado certo ou errado em si mesmo, estando seu julgamento sempre dependente da análise de suas funções e seus significados no interior de uma determinada cultura. Mas o que delimita uma cultura? Há muita imprecisão no pensamento pedagógico contemporâneo acerca dos critérios para se delimitar uma cultura. Ao mesmo tempo que se fala em cultura ocidental ou oriental, também se fala em cultura negra ou branca, culturas indígenas, cultura popular ou de elite, cultura das crianças ou dos adolescentes ou dos jovens, cultura gay, cultura dos surdos, cultura dos cegos, cultura escolar, cultura institucional, cultura das "tribos" juvenis etc.

Nem mesmo o uso do termo subcultura resolve esse problema, pois isso significaria a possibilidade de uma categoria que englobasse todas as subculturas, como a categoria de cultura da humanidade em geral. Mas isso entraria em choque com o princípio do relativismo. Eu diria que a imprecisão em relação ao que delimite uma cultura é necessária ao relativismo na educação, pois isso possibilita um uso bastante elástico e casuístico do termo. Não é difícil perceber que o relativismo cultural incide diretamente sobre o currículo escolar, acarretando sua fragmentação, podendo levar, no limite, ao seu desaparecimento. Como definir conteúdos que devam ser ensinados a todas as crianças se o critério de relevância ou até mesmo de veracidade dos conhecimentos é a cultura específica à qual pertence o indivíduo? Como definir-se um currículo comum a todos se não existe uma cultura que possa ser referência para todos? Se existem milhares de culturas particulares, existirão milhares de currículos? Ou o currículo escolar é dissolvido e em seu lugar é colocado um suposto diálogo entre as culturas das quais fazem parte os alunos? E o que define qual é a cultura de cada aluno: etnia, classe social, gênero, idade, local onde mora, os meios de comunicação, os programas de 
televisão, os estilos musicais, as religiões, as atividades de lazer, o esporte preferido? O relativismo, tanto em seu aspecto epistemológico como no cultural, leva a uma ausência de referências para a definição do que ensinar na escola às novas gerações.

Diante dessa indefinição, não é de estranhar que outra ideia muito difundida pelas pedagogias contemporâneas seja a de que o cotidiano do aluno deve ser a referência central para as atividades escolares. Ou melhor, são considerados conteúdos significativos e relevantes para o aluno aqueles que tenham alguma utilidade prática em seu cotidiano. Soma-se a esse utilitarismo o princípio epistemológico pragmatista de que o conhecimento tem valor quando pode ser empregado para a resolução de problemas da prática cotidiana. O pensador pragmatista norte-americano William James (1907) definiu a verdade como aquilo em que acreditar fosse melhor para nós ("'What would be better for us to believe!' This sounds very like a definition of truth"). Nessa perspectiva, o conhecimento é visto como uma ferramenta na resolução de problemas, e a prática cotidiana determinaria a validade epistemológica e pedagógica dos conteúdos escolares. Atualmente essa ideia é denominada como aprendizagem significativa ou conteúdos contextualizados. Ensinar conteúdos que não tenham utilidade no cotidiano do aluno tornou-se uma atitude antipedagógica. É cabível, porém, o seguinte questionamento: qual aplicação a teoria da evolução das espécies tem no cotidiano do aluno? Ou então, qual a utilidade, para a prática cotidiana, de se aprender na escola que não é o Sol que gira em volta da Terra e que a impressão que temos em nosso cotidiano de que o Sol se moveria em volta da Terra é causada pelo fato de a Terra girar em torno de seu próprio eixo? Uma das consequências mais perversas dessa limitação da validade do conhecimento à sua utilidade na prática cotidiana é a reprodução das desigualdades sociais e dos preconceitos que naturalizam tais desigualdades.

É compreensível que essa supervalorização do cotidiano conduza a outra supervalorização, desta feita daquele tipo de conhecimento definido por Polanyi (1967) como conhecimento tácito, isto é, um conhecimento pessoal, não verbalizado e circunstancial. Em Duarte 
(2003) esbocei uma crítica à concepção de formação de professores em cujo centro está justamente essa noção de conhecimento tácito e a correspondente desvalorização do conhecimento científico, teórico, acadêmico. Mas não é só no campo da formação de professores, nem mesmo somente no da formação profissional em geral que a supervalorização do conhecimento tácito gera seus efeitos negativos. Esse tipo de conhecimento vem ocupando um lugar cada vez maior nos currículos escolares, de início no interior do ensino dos conteúdos clássicos, e posteriormente deslocando esses conteúdos para uma posição secundária e periférica.

Se o conhecimento mais valorizado na escola passa a ser o conhecimento tácito, cotidiano, pessoal, então o trabalho do professor deixa de ser o de transmitir os conhecimentos mais desenvolvidos e ricos que a humanidade venha construindo ao longo de sua história. O professor deixa de ser um mediador entre o aluno e o patrimônio intelectual mais elevado da humanidade, para ser um organizador de atividades que promovam o que alguns chamam de negociação de significados construídos no cotidiano dos alunos. Mesmo quando os projetos surgidos nas atividades escolares demandem algum tipo de conhecimento proveniente do campo da ciência, o que articula os conhecimentos é o objetivo de formação de habilidades e competências requeridas pela prática cotidiana. Como mostrou Facci (2004), pedagogias como o construtivismo e a teoria do professor reflexivo levam a uma descaracterização do trabalho do professor, ainda que os defensores dessas pedagogias afirmem reiteradamente o contrário. E boa parte das pesquisas realizadas nas duas últimas décadas sobre o trabalho e a vida dos professores, em vez de analisar criticamente o impacto negativo das pedagogias do aprender a aprender na formação e no trabalho desse profissional, acaba por naturalizar a alienação, como mostrou o estudo realizado por Martins (2007). Não é de estranhar que, nesse contexto ideológico alienante, a difusão do construtivismo no Brasil tenha recorrido muito mais ao processo de sedução dos leitores pelos textos de autores construtivistas do que ao processo de convencimento pela via da argumentação racional e teoricamente fundamentada (Rossler, 2006). 
Passo agora à descrição das principais características de cada uma das pedagogias que lograram maior difusão no Brasil no final do século XX e início do século XXI.

\section{Algumas características das pedagogias mais difundidas nas duas últimas décadas}

A apresentação sumária e inevitavelmente esquemática que aqui farei das características dessas teorias pedagógicas tem limites e riscos. Durante quatro anos (1998 a 2002), desenvolvi um amplo estudo bibliográfico sobre o construtivismo, desde trabalhos de Jean Piaget até os autores contemporâneos, e tenho clareza quanto à existência de distintas vertentes dentro do próprio construtivismo, bem como das diferenças e divergências existentes entre os próprios autores construtivistas. Isso significa que estou consciente de que sintetizar em algumas poucas linhas todo o pensamento de uma corrente pedagógica é um ato relativamente arbitrário e que só se justifica em nome da necessidade de uma explicitação mínima do que eu entenda por construtivismo, bem como por pedagogia do professor reflexivo, pedagogia das competências, pedagogia de projetos e pedagogia multiculturalista. Analisar o debate contemporâneo sobre as teorias pedagógicas sem essa explicitação mínima seria pressupor um consenso prévio sobre o que defina cada uma dessas pedagogias e tal pressuposição tem consequências mais problemáticas do que o caráter esquemático e abstrato das formulações que aqui apresentarei.

O construtivismo tem como referência central a epistemologia genética de Jean Piaget. Nessa epistemologia a gênese e o desenvolvimento do conhecimento humano são promovidos pelo esforço de adaptação do organismo ao meio ambiente. Os esquemas de ação e de pensamento, bem como as estruturas da inteligência desenvolvem-se movidos pela ação recíproca e complementar entre, por um lado, o esforço feito pelo sujeito cognoscente na direção da assimilação do objeto de conhecimento às suas estruturas e esquemas 
mentais e, por outro, a resistência que o objeto pode oferecer a essa assimilação, gerando a necessidade de reorganização espontânea dessas estruturas e esquemas mentais para que eles se acomodem às características do objeto. Do ponto de vista pedagógico, isso significa que as atividades de maior valor educativo serão aquelas que promovam esse processo espontâneo de desenvolvimento do pensamento. Nessa perspectiva não importa o que o aluno venha a saber por meio da educação escolar, mas sim o processo ativo de reinvenção do conhecimento. Aprender o conteúdo não é um fim, mas apenas um meio para a aquisição ativa e espontânea de um método de construção de conhecimentos. Numa conferência proferida em 1947, Piaget explicitou com bastante clareza esse ponto de vista:

O problema da educação internacional é, portanto, essencialmente o de direcionar o adolescente não para soluções prontas, mas para um método que lhe permita construí-las por conta própria. A esse respeito, existem dois princípios fundamentais e correlacionados dos quais toda educação inspirada pela psicologia não poderia se afastar: 1) que as únicas verdades reais são aquelas construídas livremente e não aquelas recebidas de fora; 2) que o bem moral é essencialmente autônomo e não poderia ser prescrito. Desse duplo ponto de vista, a educação internacional é solidária de toda a educação. Não apenas a compreensão entre os povos que se vê prejudicada pelo ensino de mentiras históricas ou de mentiras sociais. Também a formação humana dos indivíduos é prejudicada quando verdades, que poderiam descobrir sozinhos, lhes são impostas de fora, mesmo que sejam evidentes ou matemáticas: nós os privamos então de um método de pesquisa que lhes teria sido bem mais útil para a vida que o conhecimento correspondente! Prejudica-se igualmente essa formação humana dando aos adolescentes aulas de civismo e de internacionalismo, se estas aulas consomem o tempo que eles teriam podido ocupar descobrindo sozinhos esse civismo ou esse internacionalismo no exercício de uma vida social organizada espontaneamente. Sempre que o discurso substitui a ação efetiva, o progresso da consciência é retardado. (Piaget, 1998, p.166, grifos meus) 
Piaget sempre foi um adepto, no terreno dos métodos didáticos, do método de trabalho em equipes e o self-government, ou seja, o mestre do construtivismo concordava com princípios pedagógicos escolanovistas. Nesse sentido, sua defesa do aprender a aprender estava em consonância tanto com o aprender fazendo, o learning by doing de John Dewey, como a ideia de educação funcional de Édouard Claparède.

A pedagogia de projetos é inteiramente compatível com essa tese piagetiana de que o método de pesquisa é mais útil para a vida do que o conhecimento que o professor ensine aos seus alunos. Aliás, o método de ensino por projetos surgiu inicialmente com William Heard Kilpatrick, colega e colaborador de John Dewey. Embora na atualidade seja utilizada a expressão pedagogia de projetos, o mais correto seria considerar o método de projetos como um dos métodos escolanovistas, o qual foi revitalizado e incorporado ao universo pedagógico contemporâneo. A ideia central do método de projetos é de que o conhecimento deve ser buscado pelos alunos a partir de necessidades de sua vida real, opondo-se aos currículos preestabelecidos nos quais o conhecimento é organizado numa sequência lógica e temporal. O pragmatismo de John Dewey é sem dúvida a base filosófica do método de projetos. Igualmente central no método de projetos é o desenvolvimento da atitude investigativa e do pensamento científico autônomo, considerados por Dewey e por Kilpatrick indispensáveis à cidadania na democracia liberal.

Essa mesma perspectiva é adotada pela pedagogia do professor reflexivo, que nada mais é do que a aplicação, à formação de professores, das ideias escolanovistas, construtivistas e do princípio da centralidade do conhecimento tácito. Desenvolvida inicialmente por Donald Schön como uma proposta para a formação profissional em geral, a teoria do profissional reflexivo ganhou larga divulgação no campo da formação de professores, especialmente associada à ideia de educação permanente ou formação continuada ou educação ao longo da vida. Segundo essa perspectiva, se as crianças e os jovens devem construir seus conhecimentos a partir das demandas de sua prática cotidiana, então a formação dos professores também deve 
seguir essa diretriz, pois o conhecimento decisivo para as decisões que o professor toma em sua atividade profissional não é aquele proveniente dos livros e das teorias, mas o conhecimento tácito que se forma na ação, no pensamento que acompanha a ação e no pensamento sobre o pensamento que acompanha a ação. Desse modo, aprender a pensar e a tomar decisões acertadas diante de situações práticas problemáticas e imprevisíveis seria um dos maiores senão o maior objetivo da formação de professores. E o maior objetivo do trabalho do professor seria contribuir para que seus alunos também aprendam a pensar e a resolver problemas postos por suas práticas cotidianas. Em suma, tudo gira em torno ao aprender a aprender e ao aprender fazendo.

A pedagogia das competências aponta para a mesma direção do aprender fazendo, da resolução de problemas e do espírito pragmático. O que há de específico nela é a tentativa de decomposição do aprender a aprender em uma listagem de habilidades e competências cuja formação deve ser objeto da avaliação, em lugar da avaliação da aprendizagem de conteúdos. Philippe Perrenoud (2000, p.3) assim explicitou os vínculos entre a pedagogia das competências e essa linhagem pedagógica que remonta aos métodos escolanovistas:

Para desenvolver competências é preciso, antes de tudo, trabalhar por problemas e projetos, propor tarefas complexas e desafios que incitem os alunos a mobilizar seus conhecimentos e, em certa medida, completá-los. Isso pressupõe uma pedagogia ativa, cooperativa, aberta para a cidade ou para o bairro, seja na zona urbana ou rural. Os professores devem parar de pensar que dar aulas é o cerne da profissão. Ensinar, hoje, deveria consistir em conceber, encaixar e regular situações de aprendizagem seguindo os princípios pedagógicos ativos e construtivistas. Para os professores adeptos de uma visão construtivista $e$ interacionista de aprendizagem trabalhar no desenvolvimento de competências não é uma ruptura.

Menos visíveis são os vínculos da pedagogia multiculturalista com o universo pedagógico aqui descrito. Mas não é casual que em 
muitos ambientes pedagógicos tenham se unido ideias oriundas do construtivismo, da educação popular e do multiculturalismo. A pedagogia multiculturalista acrescenta ao aprender a aprender a defesa do princípio da diversidade cultural e do respeito às diferenças. Questões como gênero, etnicidade, religiosidade, sexualidade, estilos de vida, entre outras, fazem parte de uma pedagogia multiculturalista. Assim como no caso do escolanovismo e do construtivismo, também no multiculturalismo existem distintas vertentes, cujas diferenças não abordarei aqui. Para meus objetivos neste texto, é suficiente assinalar que os impactos mais fortes e negativos da pedagogia multiculturalista são visíveis no campo das discussões sobre o currículo escolar. O multiculturalismo tem desempenhado o papel do cavalo de Troia que trouxe para dentro da educação escolar o pós-modernismo com toda sua carga de irracionalismo e anticientificismo.

É interessante notar uma importante aproximação entre o multiculturalismo e a filosofia pragmatista. Essa aproximação evidencia-se, por exemplo, na discussão sobre a religiosidade. $\mathrm{O}$ multiculturalismo discorda da análise marxista da religião como uma das expressões do fenômeno social da alienação. Tal análise é considerada etnocêntrica, cientificista e racionalista. Para o multiculturalismo, as religiões têm seu significado dado por seu lugar no interior de cada cultura e elas não devem ser avaliadas a partir de referências exteriores ao universo cultural ao qual pertencem. QuandoWilliam James (1907, p.115) discute as relações entre pragmatismo e religião ele afirma que "segundo os princípios pragmatistas, se a hipótese de Deus funciona satisfatoriamente, no mais amplo sentido da palavra, ela é verdadeira" ("On pragmatistic principles, if the hypothesis of God works satisfactorily in the widest sense of the word, it is true").

Poderia ser argumentado que essa concepção pragmatista do que seja ou não verdadeiro seria muito semelhante àquela expressa por Marx na segunda tese sobre Feuerbach:

A questão de saber se ao pensamento humano cabe uma verdade objetiva não é uma questão da teoria, mas uma questão prática. É na prática que o homem tem que provar a verdade, isto é, a realidade e 
o poder, a natureza citerior ${ }^{2}$ de seu pensamento. A disputa acerca da realidade ou não-realidade do pensamento - que é isolado da prática é uma questão puramente escolástica. (Marx \& Engels, 2007, p.533)

Estariam, porém, Marx e James referindo-se à mesma prática? Trabalhariam eles com o mesmo conceito de prática?

\section{Para além das pedagogias negativas}

Marx e James não têm a mesma concepção do que seja a prática social humana.

Penso que em Marx há uma distinção entre as diferentes formas e os diferentes níveis de prática social. Um desses níveis ou âmbitos é o da prática cotidiana, mas prática social humana não se reduz à cotidianidade. A prática cotidiana é apenas a forma fenomênica da totalidade da prática humana. Não se trata de afirmar que a prática cotidiana seja menos real do que outras formas de prática humana, mas sim de se compreender qual seja seu significado ontológico e epistemológico, tal como foi feito, por exemplo, por Heller (1984, 1994) em sua teoria da vida cotidiana.

O ponto de partida dessa teoria é a continuidade do processo histórico, isto é, o processo de contínua reprodução do gênero humano. Para que o gênero humano se reproduza é necessária a reprodução das pessoas e da sociedade. Quando as atividades estão voltadas predominantemente para a reprodução das pessoas, ou seja, para a continuidade da vida de cada ser humano, essas atividades constituem, segundo Heller, a esfera da vida cotidiana ou simplesmente o cotidiano. Quando as atividades estão predominantemente voltadas para a reprodução da sociedade elas constituem as esferas não cotidianas da vida humana ou simplesmente o não cotidiano.

Para Heller, portanto, uma atividade cotidiana não é uma atividade realizada necessariamente todos os dias e, igualmente, uma

2 A palavra "citerior" neste contexto significa a natureza terrena do pensamento. 
atividade pode ser realizada todos os dias e não pertencer à esfera da vida cotidiana. Por exemplo, uma atividade que realizo para minha reprodução individual é ir ao supermercado para comprar alimentos, produtos de limpeza etc. Essa é, portanto, uma atividade da minha vida cotidiana, mas não vou ao supermercado mais do que duas ou três vezes ao mês. Quando, porém, estou escrevendo um artigo ou um livro, posso fazê-lo quase todos os dias até concluir o que esteja escrevendo. Entretanto essa atividade, segundo o critério de Heller, não pode ser considerada uma atividade cotidiana, pois se trata de uma atividade que faço na condição de pesquisador para atender a uma necessidade da sociedade, na medida em que a reprodução da sociedade contemporânea necessita de pessoas que se dediquem à pesquisa. Entretanto, os próprios exemplos dados mostram que não há uma separação absoluta entre o caráter cotidiano ou não cotidiano de uma atividade. No caso do supermercado, ao comprar as mercadorias que ele vende, estou participando da reprodução da economia capitalista, ou seja, estou participando da reprodução social. No caso da atividade de escrever artigos ou livros, isso faz parte de meu trabalho como professor universitário, trabalho esse pelo qual recebo um salário que determina as condições materiais de minha reprodução individual.

A atividade de trabalho é específica ao gênero humano e, em sua forma primária, consiste na transformação da natureza com vistas à produção dos meios necessários à vida humana. $\mathrm{O}$ trabalho, que pode ser considerado a unidade antropológica fundamental, foi historicamente o solo comum a partir do qual tanto se desenvolveu a esfera da vida cotidiana, como também foram surgindo e ganhando autonomia em relação à vida cotidiana as demais esferas de objetivação da espécie humana: a arte, a ciência, a filosofia, a política e a moral. Por essa razão é que Heller define o trabalho como atividade voltada tanto para a reprodução dos indivíduos, isto é, atividade cotidiana, como para a reprodução da sociedade, isto é, atividade não cotidiana.

Do ponto de vista histórico, porém, o trabalho deve ser considerado inicialmente como uma atividade própria da vida cotidiana, pois ele estava, nos primórdios do gênero humano, voltado à sobre- 
vivência imediata das pessoas por meio da produção de instrumentos usados para obtenção de alimentos e para proteção. Tratava-se de uma atividade desde o início coletiva, a qual produziu o desenvolvimento das relações entre os seres humanos e da comunicação entre eles. Temos já nessa gênese da existência social humana três tipos de objetivação: a produção de instrumentos, a produção de formas de relacionamento e a produção da linguagem. A essas formas básicas de objetivação do gênero humano, sem as quais não pode existir nenhuma cultura, por mais primitiva que seja, Heller chama objetivações genéricas em-si. Por que objetivações "genéricas"? Porque elas constituem a objetividade social e histórica do gênero humano. Elas são a genericidade humana em sua forma objetiva. Por que objetivações genéricas "em-si"? Por que elas surgem e se desenvolvem de forma socialmente espontânea, ou seja, elas são produzidas e reproduzidas sem que os seres humanos precisem refletir sobre a existência delas. Elas simplesmente estão dadas na realidade imediata das pessoas e são reproduzidas pelas atividades cotidianas. Um bom exemplo é a linguagem oral. Uma criança aprende a falar simplesmente convivendo com as demais pessoas. Os pais da criança, quando ela nasce, não se questionam sobre como ela aprenderá a falar. Ao contrário, o questionamento só surge se não ocorre essa aprendizagem espontânea, essa reprodução espontânea da linguagem oral.

As "objetivações genéricas para-si” (ciência, arte, filosofia, moral e política) surgem historicamente a partir da esfera da vida cotidiana, mas vão aos poucos se constituindo em esferas relativamente autônomas em relação àquela, vão se distanciando da heterogeneidade própria das atividades cotidianas e se homogeneizando em esferas com características específicas. Historicamente existiram sociedades sem essas objetivações, mas seu surgimento e desenvolvimento acabaram por incorporá-las à essência humana, ou seja, não é mais possível o desenvolvimento do gênero humano sem a participação das "objetivações genéricas para-si".

A teoria da vida cotidiana desenvolvida por Heller trabalha intensamente tanto com a dialética entre objetivação e apropriação, como 
também com a dialética entre humanização e alienação (Duarte, 1993). A todo instante Heller faz a distinção entre os fenômenos que são resultantes das relações sociais alienadas e, portanto, podem ser superados historicamente, daqueles fenômenos que, embora tendo surgido no interior da sociedade alienada, constituem decisivos avanços para a essência humana e devem ser considerados valores universais a serem preservados numa sociedade que supere o capitalismo.

Em relação à esfera da vida cotidiana, Heller afirma que esta não é necessariamente alienada, ou seja, que as características das "objetivações genéricas em-si" e o tipo de relações que com elas as pessoas estabelecem em seu cotidiano não são necessariamente produtoras de alienação. Mas Heller também afirma que a superação da alienação da vida cotidiana numa sociedade socialista deverá possibilitar a superação do fosso que atualmente existe entre o cotidiano e as esferas não cotidianas da prática social.

Creio ser esse o principal aspecto que distingue a concepção marxista da concepção pragmatista de prática social. O pragmatismo identifica a prática social com a prática cotidiana, isto é, segundo a perspectiva pragmatista, a atividade e o pensamento humanos não ultrapassariam jamais a vida cotidiana. O pragmatismo ignora ou dá pouca importância às diferenças entre a vida cotidiana e as outras esferas da vida social, o que aliás o leva a contradições insolúveis como a contradição entre o relativismo epistemológico e a centralidade atribuída pelo próprio pragmatismo, ao menos em sua forma clássica, ao pensamento científico e ao método experimental.

Por não fazer distinção entre a prática utilitária cotidiana e a prática social em sua totalidade, o pragmatismo é incapaz de elaborar uma teoria da riqueza subjetiva e objetiva universal humana. Ao contrário do pragmatismo, o marxismo desenvolveu uma teoria histórica e dialética da construção da riqueza material e intelectual do gênero humano. Nos "Grundrisse”, Marx (1993, p.487-8) afirmou que a riqueza produzida na sociedade capitalista deve ser despida de sua forma burguesa e então essa riqueza se revela como: 1) a universalidade das necessidades, capacidades, prazeres, forças produtivas etc. dos indivíduos; 2) o pleno desenvolvimento do domínio humano 
das forças da natureza, incluindo-se a própria natureza humana; 3) a total explicitação das potencialidades criativas humanas sem nenhum outro pressuposto que não seja o prévio desenvolvimento histórico; 4) a transformação do desenvolvimento do gênero humano e do indivíduo em um fim em si mesmo, sem nenhum padrão de medida preestabelecido; 5) a transformação da vida do indivíduo em um processo no qual ele produz a si mesmo como uma totalidade de forças humanas.

Marx não descreveu dessa forma a riqueza humana com a finalidade de expressar sua esperança numa utopia. O que ele fez foi descrever as possibilidades reais criadas pela própria sociedade burguesa, mas cuja concretização só ocorrerá por meio de uma transformação social revolucionária que supere a lógica reprodutiva do capital.

Uma sociedade comunista deve ser uma sociedade superior ao capitalismo e para tanto ela terá que incorporar tudo aquilo que, tendo sido produzido na sociedade capitalista, possa contribuir para o desenvolvimento do gênero humano, para o enriquecimento material e intelectual da vida de todos os seres humanos. Trata-se de: superar os limites do Iluminismo sem negar o caráter emancipatório do conhecimento e da razão; superar os limites da democracia burguesa sem negar a necessidade da política; superar os limites da ciência posta a serviço do capital sem, entretanto, negar o caráter indispensável da ciência para o desenvolvimento humano; superar a concepção burguesa de progresso social sem negar a possibilidade de fazer a sociedade progredir na direção de formas mais evoluídas de existência humana.

Em termos pedagógicos, trata-se da superação das pedagogias negativas, ou seja, é necessário superar a educação escolar em suas formas burguesas sem negar a importância da transmissão, pela escola, dos conhecimentos mais desenvolvidos que já tenham sido produzidos pela humanidade. Creio que os educadores ainda não se deram conta do grande significado que pode ter para a educação a afirmação feita por Marx (1993, p.105): "a anatomia humana é uma chave da anatomia do macaco". 


\section{Referências bibliográficas}

ARCE, A. A pedagogia na "Era das Revoluções": uma análise do pensamento de Pestalozzi e Froebel. Campinas: Autores Associados, 2002.

DUARTE, N. A individualidade para-si. Contribuição a uma teoria histórico-social da formação do indivíduo. Campinas: Autores Associados, 1993. As pedagogias do aprender a aprender e algumas ilusões da assim chamada sociedade do conhecimento. Revista Brasileira de Educação, Rio de Janeiro, n.18, p.35-40, set. 2001.

Conhecimento tácito e conhecimento escolar na formação do professor (Porque Donald Schön não entendeu Luria). Educação e Sociedade, Campinas, v.24, n.83, p.601-25, ago. 2003.

FACCI, M. G. D. Valorização ou esvaziamento do trabalho do professor? Um estudo crítico-comparativo da teoria do professor reflexivo, do construtivismo e da psicologia vigotskiana. Campinas: Autores Associados, 2004.

HELLER, A. Everyday life. London: Routledge \& Kegan Paul, 1984.

Sociología de la vida cotidiana. 4.ed. Barcelona: Peninsula, 1994.

JAMES, W. Pragmatism: a new name for some old ways of thinking. New York: Longman Green, 1907. Disponível em: <http://www.brocku. ca/MeadProject/James/James_1907/James_1907_toc.html>. Acesso em: 14 out. 2007.

MARTINS, L. M. A formação social da personalidade do professor: um enfoque vigotskiano. Campinas: Autores Associados, 2007.

MARX, K. Grundrisse. London: Penguin Books, 1993.

Manuscritos econômico-filosóficos e outros textos escolhidos. São Paulo: Abril Cultural, 1978. (Col. Os pensadores).

MARX, K.; ENGELS, F. A ideologia alemã. São Paulo: Boitempo, 2007.

PERRENOUD, P. Construindo competências. Nova Escola, São Paulo, set. 2000. Disponível em: <http://revistaescola.abril.com.br/edicoes/0135/aberto/mt_247407.shtml>. Acesso em: 14 out. 2007.

PIAGET, J. O desenvolvimento moral do adolescente em dois tipos de sociedade: sociedade primitiva e sociedade "moderna". In: PIAGET, J. Sobre a pedagogia: textos inéditos. Org. e introd. S. Parrat-Dayan e A. Tryphon. São Paulo: Casa do Psicólogo, 1998. p.161-6.

POLANYI, M. The tacit dimension. Garden City: Anchor Books, 1967.

ROSSLER, J. H. Sedução e alienação no discurso construtivista. Campinas: Autores Associados, 2006.

SAVIANI, D. História das idéias pedagógicas no Brasil. Campinas: Autores Associados, 2007. 



\section{3 \\ CONSTRUTIVISMO, PÓS-MODERNIDADE E DECADÊNCIA IDEOLÓGICA}

José Luis Derisso ${ }^{1}$

Neste texto, procuro expor as linhas gerais da análise de Lukács sobre a "decadência ideológica" e traçar um fio de continuidade entre as primeiras manifestações desse processo em meados do século XIX com a chamada pós-modernidade. No plano educacional esse fio de continuidade passa pelo desenvolvimento das chamadas pedagogias ativas do movimento Escola Nova, pelo construtivismo e pela pedagogia das competências que, embora nem sempre assumida, expressa o pensamento pós-moderno. O objetivo é refletir como a produção intelectual do período da decadência interfere na educação escolar e induz a um esvaziamento de sua finalidade de ensinar, pois as expectativas que o Estado e as classes dominantes mantêm com relação aos resultados da educação escolar apontam para a formação de um cidadão pacífico, ordeiro e preparado para concorrer no mercado de trabalho, uma perspectiva muito distinta daquela que vê na escola a função de democratizar o conhecimento socialmente produzido pela

1 Graduado em História pela Universidade de São Paulo (USP), mestre em Educação pelo Programa de Pós-Graduação em Educação da Universidade Federal de São Carlos (UFSCar), doutorando do Programa de Pós-Graduação em Educação Escolar da Universidade Estadual Paulista (Unesp), campus de Araraquara. É professor de História da Rede Oficial de Ensino do Estado de São Paulo e membro do Grupo de Pesquisa "Estudos marxistas em educação". 
humanidade para formar um cidadão crítico e habilitado a transformar a realidade social superando as mazelas da sociedade capitalista.

\section{O pensamento pós-moderno}

Della Fonte (2003) e Moraes (2004) utilizam o conceito de pós-modernidade associado à ideia de uma agenda e não como uma corrente articulada do pensamento. O que torna o próprio termo "pós-modernidade" de incorreta aplicação por reportar-se a uma determinada condição da sociedade ou da cultura conforme o fizeram David Harvey e Jameson, no campo da crítica marxista (Della Fonte, 2003), e François Lyotard, para quem a pós-modernidade seria a própria superação do marxismo por que proclama o fim das "metanarrativas". Nesse sentido seria mais adequado empregar a expressão pensamento pós-moderno em vez de pós-modernidade.

O pensamento pós-moderno (ou agenda pós-moderna) implica uma revisão na concepção de ciência cunhada pela modernidade, na negação de que a razão se constitua no instrumento eficaz para a apreensão da realidade e de que por seu intermédio possamos aspirar ao conhecimento da verdade. Sendo assim, a possibilidade de interferência sobre a realidade humana e social no sentido de transformá-la conscientemente, ou seja, fazer uma revolução, fica praticamente descartada, possibilitando apenas pequenas interferências ou pequenos arranjos.

As vertentes do pensamento são diversas. Poderíamos citar o multiculturalismo, as teorias sociais construcionistas e o pós-estruturalismo, para o qual "o mundo social não é apenas uma construção social, mas uma construção social linguística ou discursiva" (Della Fonte, 2003, p.4, grifos no original), mas prefiro destacar como exemplo a teoria da complexidade ou do pensamento complexo de Edgar Morin. Essa teoria pauta-se pelo princípio da incerteza do físico Werner Heisenberg para criticar a visão linear e fragmentária da ciência moderna e para defender a tese da indeterminabilidade da verdade científica. Cabe notar que esse autor é hoje referência 
teórica para acadêmicos da área de administração de empresas e de empreendedorismo que entendem que o cenário econômico do mundo contemporâneo (globalizado) é um cenário de incerteza e de caos que exige do profissional dessas áreas além da consciência dessa situação a destreza e criatividade para atuar em tal contexto. Resulta que o que fazem esses "administradores" é justamente propor ao empreendedor que tire vantagem material da situação aferindo lucros, independentemente das implicações sociais de seus atos.

\section{A decadência ideológica}

O pensamento pós-moderno do final do século XX resulta de um processo que Lukács chamou de decadência ideológica e que consiste na degenerescência da ideologia burguesa que se manifesta, na sua forma mais aguda, após as revoluções de 1848. Segundo Marx, esse foi o momento em que a burguesia consolidou seu poder no plano político e que marca, simultaneamente, a entrada do proletariado na cena política dos principais países europeus apresentando projetos, mesmo que à primeira vista confusos, que colocavam a necessidade de dar continuidade no plano social aos avanços que a burguesia tinha conquistado com a Revolução Francesa no plano jurídico, ou seja, a igualdade perante a lei não garantia a igualdade de fato, o direito à propriedade não garantia o acesso indistinto a ela. No contexto de 1848, a burguesia não mais necessitava da revolução e muito menos do apoio das classes populares para exercer sua dominação. Para Marx, assim como para Lukács, a burguesia já havia cumprido seu papel histórico revolucionário e principiava a transformar-se de alavanca em ferrolho do desenvolvimento histórico.

No interior dos partidos socialistas de orientação marxista o debate sobre o esgotamento do caráter revolucionário da burguesia se desenvolveu na primeira metade do século XX. Lenin acusou a direção reformista dos partidos sociais democratas de se corromper material e moralmente ao defender a democracia representativa como único caminho de transição ao socialismo, e Trotsky acusou 
de traição a linha política da Internacional Comunista de constituir em cada país "frentes populares" no interior das quais os comunistas atuariam em alianças com aqueles partidos burgueses que expressassem interesses nacionais contrários aos interesses do imperialismo. Em ambos os casos, o argumento era que a burguesia como classe já havia cumprido seu papel histórico revolucionário e que o capitalismo como modo de produção nada mais teria a oferecer à humanidade a não ser desgraças e retrocessos.

Para Marx, as décadas posteriores a 1848 assistiram ao franco desenvolvimento da decadência ideológica que já havia principiado nas décadas anteriores com o desvirtuamento da economia política inglesa e com a decomposição do hegelianismo na Alemanha. A partir de então, os ideólogos da burguesia deixam de aspirar ao pleno desenvolvimento do conhecimento científico e ao conhecimento das verdades da natureza e da sociedade, que aspiraram no momento precedente, para transformarem-se em apologistas da sociedade capitalista. Lukács indica que Marx criticou, exaustiva e definitivamente, essa mudança de orientação em todos os campos - mas, sobretudo nas chamadas ciências humanas -, e utiliza essa crítica marxiana como ponto de partida para analisar a manifestação da "decadência" nas diferentes áreas das ciências sociais e na literatura. A diferença entre a época precedente e a posterior às revoluções de 1848 está no fato de que "os ideólogos anteriores forneceram uma resposta sincera e científica [...] ao passo que a decadência foge covardemente da expressão da realidade” (Lukács, 1992, p.120).

As questões fundamentais da "decadência ideológica", de acordo com a análise marxista de Lukács, são respostas aos problemas colocados pelo desenvolvimento social do capitalismo, dos quais merece destaque a intensificação da divisão social do trabalho na era burguesa. Essa especialização, combinada com a nova postura dos ideólogos burgueses ante o movimento operário em ascensão, ocasiona mudanças metodológicas nas ciências sociais com as seguintes implicações: a sociologia transforma-se numa ciência autônoma que foge da necessidade de estudar as relações sociais a partir da economia, para não desembocar na luta de classes, substituindo "a 
investigação das reais conexões causais na vida social por análises formalistas e vazios raciocínios lógicos" (ibidem, p.122); a economia foge da análise do processo geral da produção e reprodução para fixar-se na análise dos fenômenos superficiais da circulação, tomados isoladamente; e a história passa a expor a "unicidade" do curso histórico, sem levar em consideração as leis da vida social. No plano da filosofia desenvolve-se o irracionalismo (de Nietzsche ao fascismo) que "apela [...] aos piores instintos humanos, às reservas de animalidade e de bestialidade que necessariamente se acumulam no homem em regime capitalista" (ibidem, p.127).

\section{Escola Nova, construtivismo e pedagogia das competências}

O início do século XX é marcado por intensos embates ideológicos em consequência da luta de classes do proletariado e do aparecimento de correntes socialistas no seu interior. A extensão da industrialização e do trabalho livre assalariado acentuou a necessidade da expansão da escolarização que já vinha ocorrendo desde o século anterior nos países capitalistas centrais. E esse novo problema do capitalismo irá se refletir no plano ideológico com o aparecimento de pedagogias que buscam responder à necessidade de instruir os filhos dos trabalhadores formando novas gerações de proletários, porém dentro dos limites que os interesses das elites econômicas impunham. $\mathrm{O}$ movimento Escola Nova surge nesse contexto e responde a ele na perspectiva do liberalismo.

A despeito de eventuais diferenças entre os principais ideólogos do movimento escolanovista, existem algumas características comuns desse movimento educacional que aqui ressaltamos: a crítica, geralmente estereotipada, dos modelos educacionais e pedagógicos anteriores e que foram rotulados como "escola tradicional"; a mudança de foco da aprendizagem pela transmissão e centrada no professor para a aprendizagem baseada na experiência e na descoberta decorrente dessa; a ilusão de que por meio da educação se corrigiriam os males 
da sociedade; a "descoberta" da criança; e a exaltação da individualidade e da subjetividade.

O principal expoente do movimento escolanovista é o filósofo estadunidense John Dewey que sistematizou em sua produção intelectual a filosofia da educação nova com um forte destaque para o pragmatismo, ou seja, para os resultados práticos da educação escolar. Dewey antecipava há cem anos a fórmula liberal hoje em moda da formação do cidadão centrado no exercício dos direitos e deveres em prol da harmonia social, uma cidadania acrítica porque abstraída da realidade da sociedade de classes. Porém, a característica central do escolanovismo foi a proposição da mudança no foco indicado no parágrafo anterior (do professor para o aluno) e que, de acordo com os próprios escolanovistas, foi chamada de "revolução coperniciana" (Bloch, 1951), parafraseando Kant que propunha que a reflexão filosófica deveria mudar seu foco do objeto para o sujeito do conhecimento e que marcou um momento da concepção idealista na história da filosofia.

As pedagogias renovadoras marcam justamente a entrada em cena da psicologia em detrimento da filosofia. Jean Piaget é apontado por alguns historiadores da educação como um escolanovista justamente por pautar sua teoria do conhecimento e da formação da inteligência pela determinação do elemento psicológico sobre o social. Os métodos ativos, tão exaltados pelos escolanovistas, em Piaget estão fundamentados na ciência da psicologia genética.

A teoria do conhecimento de Jean Piaget sustenta-se na tese de que o conhecimento é um produto da atividade subjetiva e, como tal, só pode ser concebido como conhecimento de uma pessoa, ou seja: cada pessoa constrói o seu próprio conhecimento, isso constitui a principal base para a pedagogia denominada construtivismo. Mas o construtivismo pretende-se mais do que uma pedagogia, pretende-se a própria psicologia, pois a pedagogia não seria uma ciência, e sim um campo de aplicação dessa ciência que, para os construtivistas, é a psicologia genética. De modo que os dois termos (psicologia genética e construtivismo) acabam se confundindo no vocabulário construtivista. 
Os ideais liberais escolanovistas juntamente com a visão fragmentária de homem contido na epistemologia genética (a determinação do biológico sobre o social e a sociedade entendida como somatória ou agregação, assim como no reino animal) e com as pretensões do construtivismo de encarnar a própria ciência não deixando margem para outra possibilidade nos remetem às características da "decadência ideológica" acusada por Marx e sistematizada teoricamente por Lukács. O peso da especialização e da fragmentação das ciências, característico do período da "decadência", se faz presente no construtivismo na medida em que neste um materialismo biologizante combina-se com um subjetivismo extremado não deixando espaço para que se levem em consideração as reais conexões existentes na sociedade dos homens e como essa realidade interfere na formação da criança, que além de sujeito do conhecimento é, antes de tudo, sujeito histórico.

Na última década do século XX o construtivismo foi reelaborado e incorporado pela pedagogia das competências que tem em Phillip Perrenoud sua principal expressão pública. Nessa nova versão a pedagogia construtivista nos aparece mais pragmática, uma vez que coloca abertamente a preocupação com a adaptação do estudante à nova realidade do capitalismo globalizado. Os argumentos para orientar a educação escolar no sentido da formação de competências são parecidos com aqueles utilizados pelos ideólogos da Escola Nova para defender as pedagogias ativas, ambos dizendo responder a novas necessidades do panorama mundial: os escolanovistas às demandas da sociedade industrial e os ideólogos da pedagogia das competências às novas necessidades de um mercado globalizado, extremamente competitivo e exigente. Com esses argumentos propõem a redução dos conteúdos disciplinares e atribuem maior valor para o aprendizado que o indivíduo realiza por conta própria, para o método de aprendizado que o próprio aluno desenvolve, para o aprendizado decorrente da necessidade e do interesse do educando, do que para o próprio objeto do aprendizado, conforme Duarte (2003, p.7) identificou ao arrolar os quatro posicionamentos valorativos presentes no lema "aprender a aprender". Nesse sentido, o resultado que in- 
teressa não é a absorção do conhecimento em si, mas a forma como o indivíduo irá utilizar esses conhecimentos na vida prática. Diante disso, torna-se perfeitamente explicável a valorização excessiva da metodologia em detrimento dos fundamentos históricos, filosóficos, sociológicos e econômicos nos cursos de formação de professores.

Um documento que embasa a aplicação do construtivismo nas redes oficiais de ensino de praticamente todo o Brasil, o conhecido Relatório Delors (2001, p.51), assim expressa uma concepção histórico-metodológica de sociedade pacificada resultante de um contrato social:

Qualquer sociedade humana retira a sua coesão de um conjunto de atividades e projetos comuns, mas também, de valores partilhados, que constituem outros tantos aspectos da vontade de viver juntos. Com o decorrer do tempo, estes laços materiais e espirituais enriquecem-se e tornam-se, na memória individual e coletiva, uma herança cultural, no mais lato do termo, que serve de base aos sentimentos de pertencer àquela comunidade, e de solidariedade.

Temos aqui uma concepção de sociedade que nada tem a ver com o materialismo histórico e dialético que a concebe como produto histórico da luta dos contrários, das contradições sociais, da luta de classes. Dessa concepção de sociedade de Delors e dos coautores do Relatório decorre um fim para a educação:

Confrontada com a crise das relações sociais, a educação deve, pois, assumir a difícil tarefa que consiste em fazer da diversidade um fator positivo de compreensão mútua entre indivíduos e grupos humanos. A sua maior ambição passa a ser dar a todos os meios necessários a uma cidadania consciente e ativa, que só pode realizar-se, plenamente, num contexto de sociedades democráticas. (ibidem, p.52)

Em síntese, compete à educação valorizar as diferenças como a um patrimônio cultural a ser preservado, diferenças que comumente 
nos são apresentadas como culturais, mas, como materialistas, bem sabemos que são determinadas pelo processo histórico que, por sua vez, é determinado pela luta de classes resultantes das diferenças de acesso aos meios de produção e ao produto social.

As pedagogias do "aprender a aprender" na educação escolar exaltam o método do ensino-aprendizado e secundarizam a definição do objeto a ser conhecido. Simultaneamente, o pensamento pós-moderno relativiza a importância do conhecimento científico e chega às raias de negar a própria possibilidade de se conhecer a realidade de modo objetivo. Por isso, ganham destaque no vocabulário educacional acadêmico os termos "saberes" e "conhecimentos" para designar formas diferentes de abordar um objeto, bem como as diferentes conclusões decorrentes das abordagens. Vejamos um exemplo extremado: o que a ciência produziu no tocante à evolução das espécies constitui "conhecimento científico", enquanto o resultado da abordagem religiosa desse mesmo objeto constitui "conhecimento religioso". Cada um tem o seu valor por responder e satisfazer os espíritos, além de ajudar na resolução de questões práticas. Mas o que sobra disso tudo é que esse relativismo e esse pragmatismo nos levam a perder a referência daquilo que realmente seja o conhecimento e das exigências que devemos impor para reconhecê-lo como expressão de verdade científica.

Por conta desse relativismo, tornou-se frequente a utilização no linguajar acadêmico-educacional de expressões como "cultura escolar", em alusão àquilo que a instituição escolar valoriza, e "saber histórico escolar", como reelaboração por professores e alunos, do conhecimento produzido no campo das pesquisas dos historiadores e especialistas (Brasil, 2001).

Na medida em que o objeto de ensino é relativizado justamente naquela instituição cuja função intrínseca é a de transmitir conhecimento às futuras gerações, a perspectiva de democratização do acesso ao conhecimento socialmente produzido torna-se cada vez mais distante de sua realização. Na medida em que definimos o ato de conhecer como produto subjetivo, conforme querem os construtivistas, perdemos de vista a luta pela democratização do conhecimento 
socialmente produzido e apropriado de forma privada pela classe burguesa com fins de perpetuação de seus privilégios materiais.

A força da pedagogia das competências advém do fato de que o Estado brasileiro assumiu essa orientação pedagógica e a oficializou com a Lei de Diretrizes e Bases da Educação Nacional em 1996, e os Estados e municípios vieram na sua esteira. Os escolanovistas no seu tempo também tiveram o apoio dos governos para os quais elaboraram projetos de reformas educacionais. Esses fatos são de relevância para desmistificar o argumento segundo o qual as pedagogias ativas são progressistas e seus oponentes são tradicionais e reacionários, mesmo porque, se no passado a Escola Nova sofreu a oposição da direita religiosa, hoje o construtivismo tornou-se praticamente um consenso nas políticas educacionais de praticamente todos os partidos governistas brasileiros e suas implementações nas redes públicas de ensino podem ser adjetivadas de várias formas, menos de democráticas. Aliás, os materiais que se têm produzido com subvenções oficiais para a aplicação do ensino religioso nas escolas públicas brasileiras são de cunho construtivista, vide aqueles elaborados a partir de 2001 com patrocínio do governo do Estado de São Paulo, o que demonstra que não persistiram a velhas animosidades e que a oposição que a Igreja católica fazia aos escolanovistas em 1932 não tinha relação com os métodos pedagógicos desses (herdados pelos construtivistas), mas com as proposições de organização dos sistemas de ensino e da defesa que faziam da educação pública, gratuita e laica.

\section{Conclusão}

A reflexão desenvolvida neste capítulo toma como ponto de partida a tese de Lukács, segundo a qual existe um processo de decadência ideológica na sociedade capitalista desde o momento em que a burguesia e suas bandeiras de luta deixaram de cumprir um papel progressista no quadro da evolução histórica, e traça uma linha de desenvolvimento dessa decadência que culmina com o pensamento pós-moderno do final do século XX, passando pelas implicações 
dessa evolução no pensamento pedagógico e educacional. Essa reflexão não pretende igualar todas as correntes do pensamento aqui citadas ou analisadas com o mesmo valor negativo, mas identificar o papel e o peso objetivo jogados por algumas delas no contexto da luta de classes na sociedade capitalista e do embate ideológico dela decorrente. A tese aqui sustentada é que o controle que a burguesia exerce sobre os meios de produção e de circulação se estende para outros setores, sobretudo para o da produção do conhecimento, e impõe limites à produção científica e cultural. O relativismo e o irracionalismo são certamente as armas mais utilizadas para negar objetividade ao conhecimento (especialmente à realidade social, mas não só) e, consequentemente, negar também a possibilidade de transformação consciente dessa mesma realidade.

\section{Referências bibliográficas}

BLOCK, A. Filosofia da escola nova. São Paulo: Companhia Editora Nacional, 1951.

BRASIL. Ministério da Educação / Secretaria de Educação Fundamental. Parâmetros Curriculares Nacionais: história e geografia. 3.ed. Brasília: Ministério da Educação, Secretaria de Educação Básica, 2001.

DELLA FONTE, S. S. Filosofia da educação e "agenda pós-moderna". Trabalho apresentado no GT Filosofia da Educação. Anped. 2003.

DELORS, J. et al. Educação: um tesouro a descobrir. São Paulo: Cortez; Brasília: MEC: Unesco, 2001.

DUARTE, N. Sociedade do conhecimento ou sociedade das ilusões? Campinas: Autores Associados, 2003.

LUKÁCS, G. A decadência ideológica e as condições gerais da pesquisa científica. In: PAULO NETO, J. Lukács. São Paulo: Ática, 1992. (Coleção Grandes Cientistas Sociais).

MORAES, M. C. M. O renovado conservadorismo da agenda pós-moderna. Cadernos de Pesquisa, v.34, n.122, p.337-57, maio/ago. 2004. 



\title{
4 \\ Os CONCEITOS DE ATIVIDADE E NECESSIDADE PARA A EsCOLA Nova E SUAS IMPLICAÇÕES PARA A FORMAÇÃO DE PROFESSORES
}

\author{
Afonso Mancuso de Mesquita ${ }^{1}$
}

\section{Introdução: a revisão crítica da Escola Nova}

A Escola Nova nasce como um movimento de revisão e crítica. Seu alvo é sua própria antecessora, a assim chamada pedagogia tradicional. Para os revisores, a realidade anterior é entendida como a síntese de muitos vícios pedagógicos e sua nova forma de compreender a educação pretende-se a antítese virtuosa do que vinha acontecendo. A pedagogia nova é, por isso, reconhecida como uma das maiores reviravoltas no pensamento educacional do século $\mathrm{XX}^{2}$.

Vemos em Bloch (1951) que uma das primeiras constatações dos reformadores foi de que o empreendimento educativo tradicional era muito penoso e estafante ante seus próprios resultados. O sistema escolar via-se abarrotado de conhecimentos enciclopédicos que atormentavam mais que instruíam seus alunos. E o autor vai além:

1 Graduado em Psicologia pela Universidade Estadual Paulista(Unesp), campus de Bauru, mestrando do Programa de Pós-Graduação em Educação Escolar da Unesp, campus de Araraquara. Desenvolve pesquisa no campo da psicologia da educação, atualmente financiada pelo CNPq.

2 Os precursores da Escola Nova remontam, contudo, ao século XVIII, com J.-J. Rousseau, e ao XIX, com Dewey, Pestalozzi e Froebel. Para aprofundamento no assunto, consultar: Rousseau (1968), Cousinet (1950), Arce(2002), Eidt(2009). 
"Em verdade, o erro quantitativo revela um erro mais grave, que é qualitativo. E se nossos programas são inassimiláveis, não é somente em razão de sua massa e de seu volume, porém, mais profundamente, em razão de sua estrutura e de próprio espírito" (ibidem, p.12, grifos no original). O problema residia no centro do ser da escola tradicional, como diz o autor, em sua estrutura e espírito. Esses eram caracterizados basicamente por um sistema de ensino que visava à transmissão de conhecimento preestabelecido em currículo para seus alunos. O conhecimento escolar era visto como externo ao aluno, não correspondia necessariamente ao que eles estariam inclinados a aprender. Era entendido como uma postura dogmática da escola, que impedia o descobrimento e a expressão dos gostos pessoais. $\mathrm{O}$ centro gravitacional da escola tradicional era o professor, o livro, o adulto, portador de conhecimentos que deveriam ser dominados pelos alunos. A condição dos últimos era entendida como obrigatoriedade de assimilação passiva e heterônoma. A entrada na escola representava uma ruptura na forma de conhecimento que a criança desenvolvera. Se antes da escola ela empreendia suas experiências (salutares) por meio das quais conhecia, com a escolarização ela deveria aprender a subordinar-se aos conhecimentos importados dos professores e dos livros. Isso era visto como uma anomalia, uma separação brutal entre a experiência e a aprendizagem escolares. Anomalia essa que resultava invariavelmente na morte do ardor pelo conhecimento. A antiga pedagogia era vista, por esses motivos, não somente como ineficiente, mas como perniciosa ao desenvolvimento de seus alunos. $\mathrm{O}$ fato mesmo de os alunos não poderem seguir seus interesses espontâneos e serem forçados a centrar-se em objetos que não lhes correspondam à vontade de aprender é causa de "desintegração moral e intelectual" (ibidem, p.18).

Por essas razões, a Escola Nova via-se como uma necessária reviravolta em que os princípios mesmos da educação eram finalmente invertidos. Uma de suas características mais marcantes é a importância dada à atividade dos alunos. Se antes, para a pedagogia tradicional, o processo pedagógico era centrado no professor, na transmissão de certos conteúdos definidos em currículo, para a nova tendência, a 
atividade dos alunos assumia protagonismo inconteste. Na revisão e crítica da pedagogia tradicional, ela percebeu que a instrução catedrática que caracterizava sua antecessora não passava de uma forma perigosa de educação. Além de não favorecer o desenvolvimento, pois não se relacionava a nenhuma necessidade dos aprendizes, era ainda perniciosa a ele. Termos como "monstruosidade psicológica..." de Claparède (1958, p.145) e "heresia pedagógica..." de Dewey (apud Bloch, 1951, p.14) dão uma referência para a forma como esses teóricos analisavam a escola tradicional. Tudo estava fora de lugar e o eixo dessa desordem era a impermeabilidade entre os conhecimentos escolares e as necessidades dos alunos. Os processos pedagógicos como eram até então conhecidos foram suplantados pela funcionalidade da educação nova. Isso resultou numa mudança de centro gravitacional que não poderia passar despercebida.

Pedir assim ao educador que tenha por centro de gravidade a própria criança, é nada menos que pedir-lhe realize uma verdadeira revolução, se é verdade que até aqui, como vimos, o centro de gravidade sempre esteve situado fora dela. É esta revolução - exigência fundamental do movimento da educação nova - que Claparède compara à de Copérnico na astronomia, e que com tanta felicidade define nessas linhas: Os métodos e os programas a gravitar em torno da criança e, não, a criança a girar mal e mal em torno de um programa fixado fora dela, tal a revolução "copernicana” para a qual a psicologia convida o educador. (Bloch, 1951, p.37)

Esse é o significado profundo da expressão "revolução copernicana da educação”. A questão que não pode deixar dúvidas ao leitor é a seguinte: a Escola Nova empreendeu uma crítica total à escola tradicional, prevendo uma mudança na organização central da educação escolar, desdobrava-se necessariamente na mudança de praticamente todas as características da antiga pedagogia. Podemos dizer que a pedagogia tradicional e a Escola Nova são antíteses quase totais.

Saviani (2008, p.8) caracteriza bem no que consiste a mudança promovida pela Escola Nova. Ele diz: 
Compreende-se, então, que essa maneira [da Escola Nova] de entender a educação, por referência à pedagogia tradicional, tenha deslocado o eixo da questão pedagógica do intelecto para o sentimento; do aspecto lógico para o psicológico; dos conteúdos cognitivos para os métodos e processos pedagógicos; do professor para o aluno; do esforço para o interesse; da disciplina para a espontaneidade; do diretivismo para o não-diretivismo; da quantidade para a qualidade; de uma pedagogia de inspiração filosófica centrada na ciência e na lógica para uma pedagogia de inspiração experimental baseada principalmente nas contribuições da biologia e da psicologia. Em suma trata-se de uma vertente pedagógica que considera que o importante não é aprender, mas aprender a aprender.

Nosso tratamento à Escola Nova deve acompanhar esse excerto supracitado. Devemos tê-lo em mente, pois revela a grande amplitude das revisões escolanovistas. O próprio "ensinar" como objetivo da escola foi questionado, sendo substituído pelas aprendizagens espontâneas dos alunos, guiadas por suas necessidades e interesses. Notemos, o saber a ser transmitido pelo professor deixa a cena para dar lugar a uma escola que incentiva a atividade dos próprios alunos em busca de conhecimento.

\section{A concepção funcional da educação}

Eis-nos chegados ao âmago do problema, ao ponto a partir do qual as concepções básicas do movimento de educação nova começam a divergir fundamentalmente daquelas sobre as quais, consciente ou inconscientemente, repousa a escola tradicional. O que censura nesta é que ela "toma o avesso do princípio formulado por Rousseau: ela parte do saber do adulto que é sem relação com as necessidades da criança e procura impingi-los às nossas crianças sem cuidar de suas verdadeiras necessidades". ${ }^{3}$ (Bloch, 1951, p.14)

3 O que se encontra entre aspas na citação pertence a J. Dewey: A escola do amanhã. 
Rousseau (1968) em seu Emílio ou da educação iniciou uma discussão vital à Escola Nova. Sua obra, antes de versar sobre a educação, o faz sobre a relação entre homem e natureza em um mundo de desintegração, de alienação. ${ }^{4}$ Em sua percepção, o homem, quanto mais se afastava da natureza, mais degenerado se tornava. Quanto mais se socializava, mais fracionava-se, preso e suprimido pelo corpo social. A criança para Rousseau, ao contrário, é mais ligada à natureza que o adulto, estava mais próxima de sua própria raiz. Assim sendo, a criança era decisivamente distinta do adulto. E a ignorância dessa distinção foi um dos grandes alvos de denúncia do movimento escolanovista. O homem acabava procurando o adulto, a si mesmo, na criança, sem atentar para o que ela realmente é. Nesse sentido qualificava a criança negativamente, pelos seus atributos faltantes, e não conseguia apreendê-la positivamente, pelos seus atributos reais e presentes. Para os autores da Escola Nova, essa ignorância do adulto em relação às especificidades do ser infantil aparecia claramente na forma como se fazia a educação tradicional. O centro de seu processo era o adulto instruído, a criança deveria, pela força e tempo do processo educativo, tornar-se também adulto instruído. Nada é mais errado que esse princípio para os discípulos de Rousseau. Para eles a questão era exatamente a oposta. A escola deveria se reconciliar com a infância buscando conhecê-la, exercitando suas necessidades, confiando a ela os rumos do processo pedagógico.

No último excerto citado, Bloch (1951), nas palavras de Dewey, reitera a distinção central entre a Escola Nova e sua antecessora. A Escola Nova pretende superar o antinaturalismo, característico da escola tradicional. Para isso, relembram o preceito baconiano ${ }^{5}$ que afirma que só se pode vencer a natureza obedecendo-a (Bloch, 1951, p.34; Cousinet, 1950, p.6), isto é, submetamo-nos aos fatos. A Escola Nova, assim, buscando resgatar esses princípios fundamentais

4 Mészáros (2006, p.57) escreve sobre Rousseau: "Como podemos ver [...] o olhar de Rousseau para os múltiplos fenômenos da alienação e da desumanização é mais agudo do que qualquer outro, antes de Marx. O mesmo não se pode dizer, de seu entendimento sobre as causas da alienação".

5 Francis Bacon (1561-1626). Citação de Novum Organum. 
da formação humana, desenvolve-os como preceitos educacionais de importância estrutural. A compreensão de seus autores desse preceito e dos ensinamentos de Rousseau aplicados aos problemas pedagógicos resultou no que podemos chamar de:

A lei da necessidade ou o princípio funcional.

O princípio da escola ativa deriva muito naturalmente da lei fundamental da atividade dos organismos, queé a lei da necessidade, ou do interesse: A atividade é sempre suscitada por uma necessidade. Um ato que não seja direta ou indiretamente ligado à necessidade é uma coisa contra a natureza. É essa coisa contra a natureza que a escola tradicional se mata por obter de seus infelizes alunos: fazer coisas que, para eles não correspondem a nenhuma necessidade. [...] Um ato normal deve ser sempre funcional, isto é, deve ter sempre como caráter realizar os fins capazes de satisfazer a necessidade que o fez nascer. Suprima-se a necessidade prévia, e está suprimida a causa do ato. A escola tradicional reclama esta monstruosidade psicológica: atos que não correspondem a nenhuma necessidade: logo, atos sem causa. A escola ativa, ao contrário, é baseada no princípio da necessidade. Para fazer que vosso aluno aja, colocai-o em circunstâncias tais que sinta a necessidade de executar a ação que dele esperai.

A escola ativa só tem esse fundamento psicológico. Esse princípio funcional, notemos bem, não é uma simples opinião, uma hipótese metafísica: é a expressão de um fato de observação de todos os dias e de todos os instantes. É a necessidade que mobiliza os indivíduos, os animais, os homens; é ela a mola da atividade. É o que se verifica sempre e por toda parte - salvo nas escolas, é verdade, porque as escolas estão à margem da vida. (Claparède, 1958, p.145-6, grifos no original)

A educação funcional é uma obediência à natureza na visão de seus autores, pois preconiza a vinculação de todos os atos do aprendiz às necessidades que os suscitaram. No caso da escola, a necessidade de aprender. Um ato que não corresponda a uma necessidade é algo contra a natureza, diz Claparède, e, sem correspondência com 
nenhuma necessidade de aprendiz, revela-se uma "monstruosidade psicológica”. Inversamente, a educação nova busca articular o binômio atividade-necessidade. A nova pedagogia define-se pela sua funcionalidade, ela é a educação funcional. Vemos reiterativamente que:

Educação funcional é a que assenta na necessidade: necessidade de saber, necessidade de investigar, necessidade de olhar, necessidade de trabalhar. A necessidade, o interesse resultante da necessidade - aí está o fator que, de uma reação, fará um ato verdadeiro. (Claparède, 1958, p.143)

Conhecer todas as necessidades, para dar à infância os meios de satisfazê-las, é sem dúvida tarefa difícil para a educação nova; mas essa é que é a tarefa da educação nova. (Cousinet, 1950, p. 100, grifo no original)

Podemos, pois, resumir tudo quanto precede e definir a grande idéia diretriz da pedagogia nova, dizendo que para ela "quanto provém de fora, sem corresponder a uma necessidade, tudo que é proporcionado muito cedo ou muito tarde, ou está fora do campo dos interesses da tenra inteligência é um mal". ${ }^{6} \mathrm{Ou}$, para exprimir a mesma verdade em sua forma positiva: "A verdadeira pedagogia consiste em exercitar uma atividade da criança conforme sua necessidade natural". ${ }^{7}$ (Bloch, 1951, p.40)

A nova pedagogia exprime suas virtudes. Ela defendia não mais o ato de ensinar, mas conhecer necessidades pueris, criar as condições para que elas fossem satisfeitas e liberar a atividade das crianças nesse sentido. Todos esses pontos, em verdade, são o mesmo, pois a única forma de conhecer as necessidades das crianças era através de sua atividade. Essa, por sua vez, se fosse funcional, nasceria com a necessidade e terminaria com ela. Não é possível, na óptica da Escola

6 Ferrière, A liberdade da criança na escola ativa.

7 Claparède, Psicologia da criança e pedagogia experimental. 
Nova, compreender atividade e necessidade separadamente, pois a funcionalidade é precisamente a ponte que as une.

Uma das implicações imediatas dessa teoria é o abandono do diretivismo pedagógico como era pensado. O papel e a função dos professores mudam radicalmente, pois eles não devem mais dirigir o processo pedagógico, mas acompanhar, auxiliar, assistir as crianças. Sua atividade anterior era o ensino, sua preocupação era se o conteúdo da disciplina foi eficientemente transmitido. Agora, sua atividade muda, ela deve fluidificar-se, se essa imagem nos ajuda. Isso quer dizer que deve, como um líquido, assumir qualquer forma. Nesse caso, a forma da atividade dos alunos. O professor da Escola Nova manipula o ambiente escolar e traz conhecimentos que possam enriquecer e favorecer a busca das crianças pelo que elas desejam saber.

Vê-se qual é, doravante, a atitude do educador-higienista. Está compenetrado, antes de tudo, da idéia de que a educação é negócio da criança e, não, seu, que a tarefa é agora dupla, que a sua como dissemos, consiste em organizar o meio, e a da criança em desenvolver-se com o auxílio. Nessa tarefa da criança, nessa atividade, ao higienista não lhe cabe intervir; não passa de testemunha. [...] Cada criança, em cada estágio, nutrir-se-á dos elementos que lhe convenham e da maneira que lhe permita assimilá-los. Assim, o higienista, como não tem mais ensino a dar, é, ao longo da duração inteira do desenvolvimento da criança, um observador atento, a notar minuciosamente todas as reações das crianças, e sempre pronto a "modificar o meio no sentido mais favorável a seu desenvolvimento". Sua atitude, que já não é de preparação nem de formação (pois não deve agir sobre o indivíduo), é de aceitação. Não critica, não julga, não deseja, olha: e enquanto, cresce, deixa-a entregue a si mesma e respeita-lhe a vontade. (Cousinet, 1950, p.138-9, grifos no original)

A atividade dos alunos, por sua vez, passa a primeiro plano. Eles agirão na escola mais que qualquer adulto. Não são casuais os nomes método ativo ou escola ativa. É a atividade dos alunos que define os rumos do processo educativo. A liberação da atividade passa a funcio- 
nar como a chave-mestre da educação nova. Permitir que as crianças se emprenhem na autoeducação é sua grande qualidade distintiva. A importância dessa liberação é tamanha que chega e ser entendida como panaceia pedagógica. Ela permite: adequar o conhecimento às necessidades, o mais absoluto respeito à infância (entendida como a idade de ouro do desenvolvimento humano), aproximar a escola da vida, intensificar as funções psicológicas exigidas pela escola, e a educação mais adequada para uma sociedade democrática.

A escola pretende ser um local protegido que favoreça o livre desenvolvimento infantil. Um ambiente rico em materiais e atrativos, que incite e facilite as explorações das crianças. O professor deve atuar como auxiliador desse processo.

O tradicionalista constrói artificialmente o meio (o programa), e se esforça para adaptar a criança a ele. A educação nova toma as necessidades da criança como dados e organiza o meio de maneira que essas necessidades nele possam ser satisfeitas, adapta, o meio à criança. (Cousinet, 1950, p.96)

Claparède (1958, p.8), citando John Locke, afirma que este compreendeu e atingiu o "âmago da concepção funcional". A frase que suscitou esse comentário é a seguinte:

Por estranhas que sejam as perguntas que uma criança possa fazer, não devemos repelir nenhuma com desprezo, nem permitir zombarias. Ao contrário, é mister responder a tudo quanto ela perguntar... mas cuidado para não lhe perturbar o espírito com explicações ou idéias que ultrapassem sua inteligência, ou com a apresentação de uma quantidade de coisas sem relação alguma com o que ela deseja saber na ocasião.

Vemos como seria a postura do professor. Ele ainda cumpre uma função, é necessário à escola e pode ensinar (Bloch, especialmente, chama atenção para isso), mas cumpre fazê-lo com cuidados. O primeiro passo é responder ao que seus alunos querem saber, de forma 
que não tente dar explicações do que não tem relação alguma com seus desejos. Deveria também adequar o meio à experiência dos alunos, organizando os materiais escolares nessa função. E, finalmente, não dar explicações que ultrapassem as formas de compreensão infantil, respeitando as formas de pensamento. Esse reposicionamento do professor deixa lugar à atividade dos alunos, coloca-os como guias e protagonistas últimos da educação escolar.

\section{Educação funcional e escola ativa}

A escola nova prioriza os métodos ativos na educação, encontra na liberação das atividades espontâneas dos alunos o seu principal caminho de coordenação pedagógica. Isso, contudo, exige alguns cuidados, não pode ser confundido com o simples abandono das crianças a si mesmas. Segundo Bloch (1951, p.124-5),

realmente, pretender que deveríamos entregar os destinos da escola ao selfgovernment ${ }^{8}$ dos alunos, ou ceder tudo à anarquia de seus interesses ou à impulsividade de suas tendências, não é oferecer uma imagem, mas uma caricatura da escola nova; é, não aplicar, mas trair os seus princípios.

Para esses autores, um erro comum em relação à Escola Nova é imaginar que qualquer atividade das crianças basta para efetivar a "escola ativa". Esse erro foi revisto e esclarecido por Claparède (1958). Para ele, dizer que as crianças estavam em atividade ou que eram ativas na escola não era somente uma explicação incompleta, era um contratempo, pois gerava uma série de interpretações equivocadas sobre a Escola Nova (encontrado até mesmo entre os integrantes do movimento). Ele substitui o termo escola ativa por educação funcional, pois entende que o segundo termo reflete mais fielmente os princípios da Escola Nova. A questão distintiva aqui

8 Autogoverno, autorregulação. 
é a função da atividade e não simplesmente sua existência. A ação é desejada como preceito escolanovista quando, e somente quando, responde a uma necessidade do agente. Essa é a questão central para esses autores. Um aluno que apenas escuta, imóvel em sua carteira, pode ser mais ativo que outro que constrói um objeto em exercícios de trabalho manual. Tudo em razão da necessidade. Segundo Bloch (1951, p.56),

importa, pois, não confundir a exigência essencial [da atividade] com as condições ou os efeitos habituais de sua satisfação. Esta exigência essencial pareceu-nos exprimir-se duma forma nem mais clara e inequívoca no conceito da educação funcional que no de escola ativa, suscetível de múltiplas interpretações. [...]. O indispensável é que ela emane de suas necessidades e exprima as exigências de seu ser profundo.

O termo atividade é para a Escola Nova ao mesmo tempo caro e insuficiente, pois "a atividade dos alunos não basta para tornar uma escola 'ativa', enquanto não se tiver dado à palavra 'atividade' seu sentido completo" (Claparède, 1958, p.142).

\section{Atividade e necessidade}

Tendo em vista que precisamos dar ao termo "atividade" seu sentido completo, debrucemo-nos sobre isso. Claparède (1958, p.150) identifica dois sentidos habituais:

Os dois sentidos da palavra "atividade".

O termo atividade é, já o disse, ambíguo. Tem pelo menos duas acepções principais, ambas legítimas. Apenas uma dessas acepções, no entanto, se acha envolvida no conceito de escola ativa. Mas as duas acepções são muito próximas. E compreende-se que os propagadores da escola ativa tenham deslizado de uma para a outra, sem dar por isso, tanto mais quanto a psicologia corrente nunca 
estabeleceu nitidamente a distinção entre elas. Importa, pois, fazê-lo agora, sucintamente. Numa primeira acepção, "atividade" tem um sentido funcional: é o sentido que consideramos anteriormente. É ativa uma reação que satisfaz uma necessidade, produzida por um desejo cujo ponto de partida está no indivíduo que age, por um móvel interno do agente. Neste sentido, atividade se opõe a coerção, a obediência, a repugnância ou indiferença. $\mathrm{Na}$ segunda acepção, "atividade" significa efetivação, expressão, produção, processo centrífugo, mobilização de energia, trabalho; opõe-se a recepção, a ideação, a sensação, a impressão, a imobilidade.

O segundo sentido exposto pelo autor expressa simplesmente um "estado de ação", denota movimento, operação. Sobre ele já demonstramos as insuficiências. Essa acepção não está envolvida diretamente no conceito de escola ativa, pois não revela as razões que levaram o sujeito a agir, apenas demonstra sua ação. Ao contrário, a atividade em seu sentido funcional está intimamente ligada à necessidade produzida por um desejo interno. Ela opõe-se a coerção, obediência, repugnância e indiferença. Isso deve ser levado seriamente em conta, pois aponta para a importância da funcionalidade para a Escola Nova e as implicações que ela traz. Quando uma atividade é funcional, ela corresponde a uma necessidade interna, surgida no interior do sujeito, por isso a pessoa não precisa ser coagida a agir, não perde sua atenção durante sua tarefa e regula por ela mesma o ritmo e a intensidade do trabalho. Tudo isso porque ela mesma é o parâmetro de tudo, sua atividade inicia-se espontaneamente e finaliza-se quando a necessidade original está satisfeita. É precisamente esse tipo de atividade a mais cara à Escola Nova. Ela preconiza que ela é natural, fluente, não opressiva, pois percorre um caminho de menor tensão, ela é funcional. A saída para os dilemas pedagógicos está na funcionalização da atividade. Para tal nada precisa ser feito senão liberar a atividade dos alunos para suas próprias necessidades internas, todo o resto virá por si mesmo.

Para entendermos a atividade, como podemos perceber, é preciso que entendamos como os autores entendem a necessidade. 
Podemos enunciar sob a forma de lei essa coordenação fundamental entre a necessidade e as reações adaptadas à sua satisfação: Toda necessidade tende a provocar as reações próprias a satisfazê-las. Seu corolário é: A atividade é sempre suscitada por uma necessidade. (Claparède, 1958, p.41, grifos no original)

A necessidade para a Escola Nova é o móvel de todas as ações, uma força que impele o organismo a agir para satisfazê-la. É, nesses termos, exigência, pois revela as carências do ser. A necessidade como tensão que deve ser desfeita vincula ser e mundo. Esse conceito, contudo, também exige um refinamento, pois em razão de sua gênese sua qualidade se transforma. Esses autores falam em basicamente dois tipos de necessidades.

Há na criança necessidades naturais e necessidades de fantasia, [...] cumpre perguntar donde vêm essas necessidades de fantasia. E a dialética em Rousseau nos fornece a resposta. Se essas necessidades não são as naturais, não estão entre os componentes da idade da simplicidade e da inocência, é porque foram introduzidas na infância pela sociedade e pela civilização, com essa sociedade e essa civilização introduziram, na vida do homem, com o luxo e com o desenvolvimento das letras e das artes, essas falsas necessidades que Rousseau e Tolstoi, um depois do outro, condenaram. Donde, "a priori”, e por definição, se uma criança manifesta uma necessidade que não seja natural, é que essa necessidade foi introduzida, de fora, pela sociedade, pois a natureza e a sociedade são as ditas únicas forças que agem sobre o ser humano para formá-lo. (Cousinet, 1950, p.87, grifos no original)

A questão decisiva para os escolanovistas é a gênese das necessidades. Elas podem originar-se no próprio indivíduo que age ou advir do meio externo. As primeiras são entendidas como as naturais, tanto no sentido de que vêm da natureza como no sentido de que são fluidas, espontâneas, verdadeiras. As demais necessidades são entendidas como artificialidades, desdobramentos perigosos da vida civilizada. 
Nota-se um acento rousseauniano evidente, especialmente em Cousinet (1950), mais influenciado por esse filósofo. Esse acento revela a centralidade do retorno à natureza. As necessidades que nascem por si próprias no ser, "em seu ser mais profundo" (Bloch, 1951, p.50), sem influências externas (como do adulto, por exemplo) são emanações da essência humana. Por esses motivos, a Escola Nova pretende sensibilizar-se integralmente a essas necessidades. Elas são componentes imanentes do ser, especialmente o ser infantil. O oposto também é verdadeiro, as necessidades artificiais ou de fantasia são impostas pela escola, pelos adultos ou pela vida civilizada. São sinais do afastamento entre o homem e sua própria essência. Elas devem ser superadas no cotidiano da escola, afinal encontram-se entre os legados da escola tradicional, com seu sistema de prêmios e sanções. Cumpre ao educador tomar cuidado para não atrapalhar o desenvolvimento das crianças inserindo necessidades de fantasia na escola.

O que, porém, ocasiona o nascimento de uma necessidade no ser? Nessa resposta crucial percebemos que os autores da Escola Nova não podem escapar do recurso à ciência biológica ${ }^{9}$ para explicar os seres humanos, e isso os aproxima radicalmente de J. Piaget, com seus modelos de desequilíbrio e reequilíbrio internos.

A ruptura do equilíbrio de um organismo é o que chamamos "necessidade". Se o organismo tem falta d'água, dizemos que tem necessidade de água. Mas essa necessidade tem a propriedade de provocar as reações próprias a satisfazê-la. Assim, o organismo que tem falta de água começará a mover-se, a procurar até achar a água necessária ao restabelecimento de seu equilíbrio vital. (Claparède, 1958, p.41)

9 O que também pode ser atestado pela seguinte passagem, que revela algumas referências de Claparède (1958, p.41): "Essa lei da necessidade, é ocioso dizê-lo, já foi observada por diversos autores. Assim, o fisiologista Pflüger escrevia em 1877: 'A causa de toda necessidade de um ser vivo é, ao mesmo tempo, a causa da satisfação dessa necessidade'. E o biologista Nägeli: 'A necessidade age como excitante"”. 
A verdade é que uma necessidade não se cria. Se nasce, com efeito, na criança (e em qualquer indivíduo) da ruptura dum equilíbrio que tende a restabelecer-se e se satisfaz pela reação a certa excitação, a um estímulo que age por si só. (Cousinet, 1950, p.94)

Entendemos ser esse o ponto conceitual básico para esses pensadores. Em última instância, eles pensam o surgimento de uma necessidade como um equilíbrio orgânico que se rompe. Esse poderia ser causado por fatores endógenos que se transformam, impulsionados pela maturação, ou por fatores exógenos como a excitação dos estímulos percebidos pelas pessoas. A atividade funcional pode ser então entendida como a busca de reequilibração dos organismos, pois a necessidade que a impulsiona existe em razão de um desequilíbrio interno. Pensemos agora esses conceitos criticamente.

A crítica quase sempre exige o contraponto. Deveríamos expor princípios contrários a esses para, a partir deles, identificar problemas e divergências. Não há condições nem necessidade de "partirmos do zero" neste momento, pois essa discussão está avançada no campo teórico. Assumiremos aqui os conceitos e posicionamentos da pedagogia de inspiração marxista que nos dá suporte, a pedagogia histórico-crítica. Mais especificamente, gostaríamos de referir-nos à análise empreendida por Duarte (2004) em Vigotski e o "aprender a aprender". Nessa obra o autor analisa, a partir de Vigotski e do referencial teórico-metodológico marxista, o pensamento de Jean Piaget. Ele se debruça sobre o desenvolvimento do pensamento na óptica piagetiana. Nesse estudo, identifica e mostra aos leitores que, para além de uma questão pontual, a questão problemática e subjacente ao pensamento de Piaget em toda a sua trajetória como intelectual é a naturalização e universalização a-histórica dos seres humanos.

O fenômeno da naturalização e conseqüente universalização a-histórica das características humanas em Piaget, que está presente em sua concepção do egocentrismo intelectual, moral e afetivo, é o caminho por meio do qual o pensador suíço julgou encontrar um ponto de referência para definir o que é a verdade. Piaget, com sua 
conhecida aversão à filosofia, por ele identificada com a metafísica idealista, entendia que o único caminho para escapar ao sujeito transcendental seria recorrer ao substrato biológico da lógica que presidia o processo de evolução (ou de construção) do conhecimento humano. (Duarte, 2004, p.266)

Essa forma de derivar explicações provenientes das ciências naturais para explicar os fenômenos humanos é tida pelo pensamento marxista como um limite teórico absoluto (além de um grave problema ideológico), não basta para compreender ao homem. A análise do pedagogo brasileiro demonstra que Piaget deparara constantemente com esse limite de sua própria forma de pensar o homem. Ele afirma que o pensador suíço, aliás, não compreendeu a amplitude e a profundidade das críticas vigotskianas dedicadas ao seu pensamento, pois não percebeu que essas feriam diretamente os fundamentos, as bases, desse pensamento. Ele deveria rever radicalmente sua forma de ler a realidade para compreender Vigotski, o que não aconteceu. $\mathrm{O}$ fato de Piaget não conseguir superar os limites apontados deve-se ao fato de que toda teoria, por uma exigência da própria lógica que a constitui, deve preservar-se como um sistema coerente e coeso. Dessa forma, ou Piaget revia seus pressupostos básicos, ou não poderia perceber e superar os desdobramentos equivocados deles. Vigotski, simplesmente golpeando a base do pensamento de Piaget, fez que todo o seu "edifício teórico" ruísse.

Isso posto, perguntamo-nos: a dinâmica entre atividade e necessidade não ocuparia também uma posição central dentro do sistema teórico escolanovista? E, sendo a referência à biologia a base para a compreensão da dinâmica das necessidades, não seriam também as afirmações daí derivadas igualmente problemáticas? Parece-nos, por tudo isso, que a qualidade da qual a Escola Nova mais se orgulhava, qual seja, o retorno à natureza, é precisamente seu ponto mais frágil, uma vez que a compreensão desses autores sobre a natureza é extremamente contestável. Não pretendemos encerrar essas questões por ser essa análise ainda incipiente e haver necessidade de pesquisa mais aprofundada, mas podemos marcar aqui essas questões como 
hipóteses que servirão a cada leitor como balizamento e auxílio para seus estudos. Mesmo assim, podemos ensaiar mais um passo.

Um desses desdobramentos problemáticos pode ser exemplificado pela postura da Escola Nova em deixar as crianças o máximo de tempo possível na infância [postura essa comum à atual pedagogia da infância, como analisou Arce (2004)]. Para esses autores, a influência do adulto na escola, inculcando falsas necessidades distantes de sua natureza "purificada", é, além de antipedagógica, perniciosa ao desenvolvimento infantil. Cumpre ao educador não criá-las, deixando as crianças livres para agir em razão do que surge como impulso em seus próprios seres. As necessidades naturais são entendidas como as que nascem sem nenhuma influência do adulto. Ora, encaremos essa questão com frieza. Existiriam mesmo necessidades que surgem no ser sem nenhuma influência dos adultos e da vida em sociedade? Não, não pode existir tal coisa na vida humana. Isso porque nossas necessidades, todas elas, são profundamente históricas. Isso está firme e claro desde Marx \& Engels (2007), o primeiro ato histórico é a produção das formas de satisfação das próprias necessidades, e essa satisfação cria já novas necessidades, profundamente históricas. Dessa forma, o homem transforma as circunstâncias de sua vida e ao mesmo tempo é constituído por elas. Tudo isso é feito conscientemente, o que, apesar de não considerado pelos escolanovistas, muda radicalmente a condição humana. Assim, não podem existir circunstâncias sociais ou necessidades que não possuam raízes na história do homem sobre a Terra. As necessidades humanas são constituídas não somente da influência social do presente, mas de uma influência social que sintetiza presente e passado.

Além do ponto de vista filosófico e ontológico rapidamente exposto, há também, para não nos restar dúvidas, a análise feita por D. Elkonin (1987) da periodização do desenvolvimento humano. Ela demonstra, do ponto de vista psicológico, como nossas necessidades se desenvolvem, desde a mais tenra idade, em razão basicamente de três fatores inseparáveis: da nossa própria atividade, do convívio com os demais seres humanos e dos objetos da cultura. Não há necessidades que surgem descoladas da vida real da criança, cheia de 
pessoas e objetos. Elas são ainda função de uma ligação psicológica especialmente voltada aos adultos. As necessidades e a atividade se edificam ao longo da vida e se revolucionam uma série de vezes. Não pode haver necessidade humana sem atividade, história, cultura e sociedade.

Além da existência duvidosa de necessidades puramente naturais, outro desdobramento que pode ser revisto a partir do exposto é a formação de professores sob a óptica escolanovista.

\section{A formação de professores pela Escola Nova}

Finalizando nossa exposição, vejamos o que dizem alguns pensadores escolanovistas diretamente sobre a formação de professores.

Essa nova concepção da escola e do educador implica uma transformação completa na formação dos professores, do ensino de todos os graus. Essa preparação deve ser, antes de tudo, psicológica. (Claparède, 1958, p.173, grifos no original)

Se tal é, de hoje em diante, a atitude do educador-higienista, vê-se qual pode ser sua preparação. Aquilo a que se chama ordinariamente "os estudos" não têm, nessa preparação, importância primordial. Não há dividir-lhe a existência em duas partes, a primeira das quais consagra à aquisição de certo número de conhecimentos, a segunda à transmissão desses conhecimentos aos alunos. (Cousinet, 1950, p.139)

"A formação é antes de tudo psicológica" e "os estudos não têm importância primordial”. Nada mais natural para os escolanovistas. Partindo da constatação de que o desenvolvimento dos alunos não depende da aquisição de conhecimentos na escola, mas de uma atividade livre e automotivada, é esperado que os professores formados sob essa perspectiva não devam necessariamente instruir-se sistematicamente na preparação para a docência. $O$ caráter naturalizante presente nos conceitos de atividade e necessidade leva os 
pensadores do movimento a verem na educação funcional, mais que na apropriação da cultura, o fator de humanização decisivo. Assim, os professores devem estar preparados não para ensinar os conteúdos das respectivas disciplinas, mas para não intervir na atividade das crianças, a não ser para assisti-las em seu próprio empreendimento educativo. A preparação psicológica refere-se a possíveis dificuldades do docente em perceber até que ponto não responde a suas próprias necessidades em sala de aula. Isso não é literal e claro em Claparède, mas parece-nos uma interpretação coerente.

Arce (2005, p.53) analisa a formação de professores sob a óptica construtivista. Em seu texto, a autora destaca, entre outras características específicas ao construtivismo, uma sistemática desvalorização da aquisição de conhecimentos.

É então desfechado um ataque maciço à formação fornecida pela universidade, que se caracterizaria por uma abordagem "empirista", a qual levaria à tentativa de "encher" a cabeça dos futuros professores com uma série de conteúdos que de nada servirão para sua prática.

Constatamos que ambos, Escola Nova e construtivismo, possuem um ponto em comum, afirmam que a aquisição de conhecimentos na formação de professores não tem valor intrínseco. Ora, esse não seria mais um indício da proximidade entre essas duas vertentes do pensamento educacional, como compreende Duarte (2004) a partir da categoria das pedagogias do "aprender a aprender"? Isso não atestaria também o fato de que muitas das análises e conclusões referidas a essas teorias da educação, tomadas as precauções devidas, podem ser mutuamente estendíveis? Cabe ao leitor pensar sobre isso.

Esperamos ter reunido elementos suficientes para compreendermos melhor o significado dos conceitos em foco e suas implicações para a formação de professores. O retorno teórico à Escola Nova é atual enquanto seus preceitos e formas de ler a realidade persistirem no cotidiano das escolas. Esperamos, por isso, ter contribuído para o refinamento analítico das pedagogias do "aprender a aprender" e para a transformação da realidade educacional que testemunhamos. 


\section{Referências bibliográficas}

ARCE, A. A pedagogia na era das revoluções: uma análise do pensamento de Pestalozzi e Froebel. Campinas: Autores Associados, 2002.

Pedagogia da infância ou fetichismo da infância. In: DUARTE, N. (Org.) Crítica ao fetichismo da individualidade. Campinas: Autores Associados, 2004.

A formação de professores sob a ótica construtivista: primeiras aproximações e alguns questionamentos. In: DUARTE, N (Org.) Sobre o construtivismo. Campinas: Autores Associados, 2005.

BLOCH, M. A. Filosofia da educação nova. São Paulo: Companhia Editora Nacional, 1951.

CLAPARÈDE, E. A educação funcional. São Paulo: Companhia Editora Nacional, 1958.

COUSINET, R. A educação nova. São Paulo: Companhia Editora Nacional, 1950.

DUARTE, N. Vigotski e o "aprender a aprender": críticas às apropriações neoliberais e pós-modernas da teoria vigotskiana. Campinas: Autores Associados, 2004.

EIDT, N. M. A educação escolar e a relação entre o desenvolvimento do pensamento e a apropriação da cultura: a psicologia de A. N. Leontiev como referência nuclear de análise. Araraquara, 2009. Tese (Doutorado) - Faculdade de Ciências e Letras, Universidade Estadual Paulista "Julio de Mesquita Filho".

ELKONIN, D. Sobre el problema de la periodización del desarrollo psíquico en la infancia. In: DAVÍDOV, V; SHUARE, M. (Org.) La psicologia evolutiva y pedagógica en la URSS: Antologia. Moscú: Editorial Progresso, 1987.

MARX, K.; ENGELS, F. A ideologia alemã: crítica da mais recente filosofia alemã em seus representantes Feuerbach, B. Bauer e Stirner, e do socialismo alemão em seus diferentes profetas. São Paulo: Boitempo Editorial, 2007.

MÉSZÁROS, I. Teoria da alienação em Marx. São Paulo: Boitempo Editorial, 2006.

ROUSSEAU, J. J. Emílio ou da educação. São Paulo: Difusão Europeia do Livro, 1968.

SAVIANI, D. Escola e democracia. Campinas: Autores Associados, 2008. (Edição comemorativa). 


\section{5 \\ Alienação e emancipação \\ NA TRANSMISSÃO DO CONHECIMENTO \\ ESCOLAR: UM ESBOÇO PRELIMINAR}

Mauro Sala

Neste trabalho não discutiremos a questão da alienação e da emancipação na transmissão do conteúdo escolar no sentido que hegemonicamente é dirigida essa discussão. Aqui, não abordaremos a questão sob o foco técnico-pedagógico, ou didático. A questão que se impõe para nós não é propriamente a da forma de transmissão do conhecimento: se essa é mais ou menos autoritária, se ela respeita ou não a estrutura do conhecimento que busca transmitir, questões que certamente apresentam grande importância para a prática escolar. Não é o processo que aqui entra em questão, mas o próprio conteúdo. De maneira geral, o problema que nos colocamos é de que uma sociedade que permanece fundamentalmente contraditória em sua estrutura não pode ser totalmente integrada nos conhecimentos que formula.

Com isso não queremos nos aproximar das teorias crítico-reprodutivistas da educação e nem das teorias dualistas da cultura e da escola. O que queremos é entender como aquela contradição também se manifesta na educação escolar marcando o próprio conteúdo escolar, não com o objetivo de afastá-lo ou secundarizá-lo, mas de compreender os riscos e as possibilidades que ele comporta.

1 Graduado em Ciências Sociais pela Universidade Estadual Paulista (Unesp), campus de Araraquara, mestre pelo Programa de Pós-Graduação em Educação Escolar da Unesp, campus de Araraquara. 


\section{A especificidade da educação escolar e suas contradições}

Temos definido a escola como uma instituição cujo papel central é a socialização do conhecimento historicamente elaborado e acumulado pela humanidade, ou seja, temos definido como seu objetivo principal a transmissão-assimilação do saber sistematizado, o que significa definir como atividade nuclear da escola o ensino e a aprendizagem dos conteúdos escolares, historicamente construídos e definidos.

Esse não é um ponto de vista arbitrário. É sobre a base da questão da socialização dos meios de produção que consideramos fundamental a socialização do saber elaborado, ou seja, sobre a dupla perspectiva de que também os conhecimentos fazem parte dos meios de produção, e de que também eles podem concorrer para a superação da sociedade centrada na propriedade privada. Assim, temos claro que a socialização do conhecimento historicamente elaborado é apenas uma possibilidade se não tocarmos as questões prático-materiais que determinam a forma privada de apropriação das riquezas materiais e espirituais.

Isso não significa que vejamos a escola fadada a reproduzir toda estrutura hierárquica de exploração da sociedade capitalista. Que a escola, tal como conhecemos hoje, seja fruto da sociedade capitalista não impede que nela também se desenvolvam elementos contraditórios que concorrem para a superação dessa sociedade. A própria função que essa escola desempenha no seio da totalidade social pode guardar esse potencial explosivo.

A formulação de que a escola deve socializar o conhecimento para a inserção do trabalhador no processo de valorização do capital, mas fazendo "em doses homeopáticas" (Adam Smith), evidencia o caráter ambíguo do posicionamento burguês ante a questão da educação escolar. Sabe que é necessária, mas deve conter os elementos que possam evidenciar ou fomentar a descoberta da própria estrutura da sociedade, que não é apenas contraditória, mas hierarquicamente contraditória, com o domínio e a exploração de uma classe sobre a outra. 
Mesmo que a educação institucionalizada tenha, no desenvolvimento da sociedade capitalista, servido - em sua quase totalidade - ao propósito não só de fornecer os conhecimentos e o pessoal necessário à máquina produtiva em expansão do sistema do capital, como também de gerar e transmitir um quadro de valores que legitima os interesses dominantes, como se não pudesse haver nenhuma alternativa (Mészáros, 2005), isso não altera essencialmente a questão, pois as possibilidades objetivas que a escola contém dizem respeito antes às suas contradições imanentes que ao seu desenvolvimento imediato, embora esse também não possa ser negligenciado.

Newton Duarte $(1993 ; 2004)$ tematizou a questão da alienação e da humanização a partir, sobretudo, da questão da objetivação e da apropriação. Aqui, não a tematizaremos por esse enfoque, embora as possibilidades contidas no processo de objetivação e apropriação sejam indispensáveis para o nosso próprio problema, ou seja, sem a apropriação por parte dos indivíduos das objetivações social e historicamente constituídas, o nosso problema nem sequer se colocaria; pois o que discutiremos é como o próprio conhecimento escolar, que deve ser apropriado pelos alunos, traz a marca da sociedade que o formulou, e que para todos os efeitos permanece contraditória.

Assim, não traçaremos uma relação direta entre apropriação do conteúdo escolar e humanização do aluno, o que, de fato, também não faz o professor Newton Duarte. A dialética entre alienação e emancipação também é imanente ao próprio conteúdo escolar, pois a própria ciência também é tolhida pela relação entre capital e trabalho, a qual não pode superar; o que não significa negligenciá-la ou reduzi-la simplesmente à ideologia.

Se no campo do pensamento burguês a educação escolar aparece também como um risco, por isso deve ser ministrada em doses homeopáticas, para os marxistas ela não pode aparecer apenas de forma afirmativa e não crítica; pois, embora em um sentido diverso, ela também deve ser entendida como contendo um risco: o de servir apenas ao processo de valorização do mundo das coisas.

Na base da divisão social do trabalho o próprio processo de apropriação se converte também em um fenômeno de alienação, 
assim como as objetivações do trabalho humano quando reduzidas à grandeza abstrata, à mercadoria. Essa característica da sociedade de classes também marca as objetivações e apropriações no campo da cultura e da ciência.

Marx (1983, p.17) já havia mostrado como a ciência econômica burguesa havia se convertido "em atividade de espadachins assalariados" no momento mesmo em que essa classe torna-se a historicamente dominante:

Já não se tratava de saber se este ou aquele teorema era ou não verdadeiro, mas se, para o capital, ele era útil ou prejudicial, cômodo ou incômodo, subversivo ou não. No lugar da pesquisa desinteressada entrou a espadacharia mercenária, no lugar da pesquisa científica imparcial entrou a má consciência e a má intenção da apologética.

Lukács (1968, p.52), que soube ler bem esse processo, caracteriza-o como processo de "decadência ideológica da burguesia", que surge como tendência à mistificação:

Essa liquidação de todas as tentativas anteriormente realizadas pelos mais notáveis ideólogos burgueses, no sentido de compreender as verdadeiras forças motrizes da sociedade, sem temor das contradições que pudessem ser esclarecidas; essa fuga numa pseudo-história construída a bel-prazer, interpretada superficialmente, deformada em sentido subjetivista e místico, é a tendência geral da decadência ideológica.

Adorno \& Horkheimer (1985, p.11), por sua vez, buscaram mostrar que o próprio esclarecimento, congelado pelo temor da verdade, converte-se em mito, dizendo que diante do "colapso atual da civilização burguesa, o que se torna problemático não é apenas a atividade, mas o sentido da ciência”. Assim, o que se põe em questão é o processo pelo qual a própria ciência pretende se autonomizar de qualquer fim realmente humano, passando a transitar, pela sua forma e pela sua estrutura, para a barbárie. 
Mészáros (2004), buscando encontrar os fundamentos materiais desse processo na "produção destrutiva" do capital como expressão de sua crise estrutural, diz que, articulado com o desenvolvimento do complexo industrial-militar, a ciência vive um processo de "tecnificação", no qual transformar-se-ia num "ofício de técnicos engenhosos". Para esse autor, no quadro da atual divisão do trabalho, "a ciência, fragmentada e dividida é direcionada para tarefas e problemas reificados produzindo resultados e soluções reificados", tornando-se "não apenas de fato, mas por necessidade - em virtude de sua constituição objetiva sob as relações sociais dadas -, ignorante e despreocupada quanto às conseqüências sociais de sua profunda intervenção prática no processo de reprodução social expandida". Segundo Mészáros, a ciência vem cada vez mais sendo "transformada e degradada à condição de 'ciência aplicada' do complexo industrial-militar" (ibidem, p.243-300).

O que se coloca em questão é o processo pelo qual a ciência compete para a mistificação. Seja por seu engajamento de classe, pela crítica de seu próprio sentido ou pela função destrutiva que exerce, esse é um fenômeno que surge na sociedade burguesa no momento do perigo: das lutas da nova classe revolucionária e do aprofundamento em uma nova barbárie.

O entendimento desse processo como tendencial, e não como unívoco, prende-se ao pressuposto de que uma sociedade que permanece fundamentalmente contraditória em sua estrutura não pode ser totalmente integrada no plano da consciência. Não se trata de fazermos uma identificação unilateral e mecânica entre o desenvolvimento da luta de classes e suas determinações no campo da ciência, mas de compreendermos de como esse campo de objetivação só pôde ser constituído na base da divisão social do trabalho e de seu desenvolvimento histórico.

Podemos dizer então que a visão de que a ciência tem autonomia ante o desenvolvimento das contradições sociais concretas é uma ilusão socialmente necessária, ou seja, uma ideologia baseada na divisão entre o trabalho manual e intelectual que forja a impressão de que a produção material e a intelectual se constituem como 
esferas essencialmente distintas; o que é tanto fator de possibilidade de desenvolvimento do conhecimento quanto de sua alienação, o que não significa que todo o produto dessa relação alienada seja alienação.

Não podemos recorrer à velha separação burguesa entre mundo espiritual e mundo material, como se esse fosse o espaço das agruras e aquele o da realização do indivíduo; como se a materialidade fosse o campo incontornável das necessidades e dos conflitos e a cultura o mundo eternamente melhor e aperfeiçoável do indivíduo, que pode se realizar a partir de si mesmo, sem ter que transformar a realidade (Marcuse, 1997). É nessa pretensa separação que se encontra o grande risco de a socialização dos conhecimentos escolares se transformar em socialização da dominação de classe, se tornando instrumento de inculcação da ideologia dominante e produção de mão de obra para azeitar o funcionamento macio da maquinaria. Desse ponto de vista devemos nos afastar.

Dizer que a escola deve socializar os conhecimentos historicamente sistematizados e elaborados pela humanidade não pode significar tomá-los abstratamente ou em sua pretensa autonomia e neutralidade. Essa formulação deve reconhecer o caráter materialmente determinado do conhecimento, bem como reconhecer a própria materialidade como um desenvolvimento contraditório, o que significa abordá-los criticamente.

É justamente pelo fato de o conhecimento não poder ser totalmente integrado e harmonizado no plano da ideologia dominante que decorre o temor burguês e sua recomendação taxativa de educar "em dose homeopática”. Pois se, por um lado, o marxista deve se afastar de uma concepção de conhecimento tomado como uma esfera separada da existência material, por outro, a burguesia já tinha adquiridocomo diz Marx (s. d., p.237) - a "noção exata do fato de que todas as armas que forjara contra o feudalismo voltavam seu gume contra ela, que todos os meios de cultura que criara rebelavam-se contra sua própria civilização, que todos os deuses que inventara a tinham abandonado", ou seja, ela passou a perceber uma tendência hostil nas potências que liberou, o que nos faz ver que também nesse caso 
não podemos fazer apenas uma identificação mecânica e abstrata entre classe dominante e produtos sociais.

Marx já mostrou porque se trata de uma falsidade caracterizar a burguesia como classe produtora, seja lá do que for. Ele mostrou que os produtores, no capitalismo, não são aqueles que detêm os meios de produção, mas aqueles que vendem sua força de trabalho por um salário, sendo a burguesia a classe que se apropria dos produtos que outras mãos produziram. Assim, também no campo da produção simbólica não podemos conceber a burguesia como a classe produtora, embora nesse caso ela tenha alguma participação. Aqui também ela é fundamentalmente a classe que se apropria do que, a rigor, não foi ela quem produziu. Entretanto, quem controla os meios de produção material também controla os espirituais, o que certamente também marca seus produtos, mas também de forma contraditória.

Assim como não é pelo fato de no desenvolvimento do capitalismo termos criado necessidades de consumo puramente fictícias o que Marcuse (1978) chamou de "necessidades repressivas" que servem apenas à reprodução do capital - que devemos colocar toda a produção material sob esse signo, também não é pela tendência da ciência à decadência ideológica e da cultura à sua industrialização capitalista que devemos fazer tomar a totalidade de seus produtos como ciência apologética ou indústria cultural, embora no capitalismo contemporâneo esse peso não possa ser menosprezado.

Como, porém, buscamos nos afastar de uma teoria dualista da ciência e da cultura (embora em alguns caso o dualismo seja inevitável), devemos dizer que não se trata aqui de uma oposição entre cultura e ciência alienada e emancipada, em que o afastamento da primeira fosse a condição para a elaboração da segunda. Tal procedimento só pode redundar em alienação e formulações dogmáticas e apologéticas: primeiro por ser impossível superar apenas no plano da teoria as contradições e a alienação que se manifestam prática e materialmente; segundo, porque a formulação de qualquer crítica superadora (bem como de um movimento histórico revolucionário) passa pela apropriação e assimilação da totalidade das relações sociais 
e dos produtos materiais e espirituais, mesmo que esses fatalmente contenham e reproduzam alienação. ${ }^{2}$

A negação não pode se dar apenas por um afastamento do objeto, mas passa também por um mergulho em suas contradições imanentes, o que significa dizer que, num certo sentido, a própria negação liga-nos ao objeto negado; reproduzindo sua estrutura contraditória, mas também podendo captar as possibilidades objetivas que nela se desenvolvem.

Certamente o temor burguês ante a universalização da possibilidade de apropriação pelos indivíduos da totalidade das objetivações sociais não se dá pelo sentido da contradição que formulamos antes, ou seja, de que os conteúdos forjados no seio da sociedade de classes também trazem a marca da alienação. Esse temor na verdade se faz pelo avesso do que formulamos. Ele se dá não pela compreensão de que a contradição social também confere um elemento de alienação aos conteúdos escolares (o que a burguesia também não desconhece), mas pelo reconhecimento de sua universalidade imanente que não pode se realizar na base da divisão social do trabalho e do domínio da classe burguesa, e que, portanto, solicita a sua superação.

Marx nos ensinou a ver o desenvolvimento do capitalismo ao mesmo tempo positiva e negativamente. Assim, busca-se captar os traços demonstravelmente sinistros do capitalismo, como também o seu dinamismo extraordinário e libertador de uma só vez, sem atenuar a força de nenhum desses julgamentos. Ele nos ensinou a elevarmos nosso espírito a um ponto a partir do qual seria possível compreender que o capitalismo é ao mesmo tempo a melhor coisa que aconteceu e a pior. Certamente, podemos dizer que o traço mais sinistro do desenvolvimento capitalista é o fato de que desse dinamismo extraordinário e libertador a maioria dos indivíduos está apartada. De fato, diz Marx nas teorias da mais-valia, esse desenvolvimento

2 O fato ecológico-concreto de que o padrão de vida de um estadunidense médio seja impossível de ser generalizado para o conjunto da população não tem a força de negar o que foi dito, mas sim de caracterizar a necessidade de superação de uma sociedade na qual os produtos sociais aparecem como "ontologicamente" não socializáveis. 
se faz em detrimento da maioria dos indivíduos. "A expansão a um nível mais elevado da personalidade só pode ser atingido graças a um processo histórico no qual os indivíduos são 'sacrificados'."

Noutro lugar, escreveu Marx (1987, p.89-90):

Os indivíduos universalmente desenvolvidos - cujas relações sociais, enquanto relações que lhes são próprias e comuns, são igualmente submetidas ao seu controle comum - não são um produto da natureza, mas da história. O grau e a universalidade do desenvolvimento das faculdades, que tornam possível esta individualidade, pressupõe precisamente a produção baseada sobre os valores de troca, pois só ela produz a universalidade da alienação do indivíduo para consigo mesmo e para com os outros, mas igualmente a universalidade e omnilateralidade das suas relações e capacidades. Em épocas mais antigas de seu desenvolvimento, o indivíduo singular revela-se mais completo, precisamente porque ainda não elaborou a plenitude de suas relações e ainda não as contrapôs a si mesmo como potências e relações sociais que são independentes dele. Se é ridículo alimentar nostalgias por aquela plenitude originária, é igualmente ridículo crer que se deva manter o homem neste completo esvaziamento.

Assim, Agnes Heller (1992, p.38) pôde definir alienação como o "abismo entre o desenvolvimento humano genérico e as possibilidades de desenvolvimento dos indivíduos humanos, entre a produção humano-genérica e a participação consciente do indivíduo nesta produção". Dessa forma, a superação da alienação pressupõe a apropriação pelos indivíduos dessas relações "universais e omnilaterais" e da realização para os indivíduos de suas possibilidades. Em última instância, a alienação

nada mais é que uma ruptura na qual a evolução da humanidade se destaca da evolução do indivíduo, na qual o efeito - que modifica e desenvolve o homem - da atividade apresenta-se apenas como relação social global, mas não como elemento capaz de provocar a formação do indivíduo, o desenvolvimento da personalidade e de sua atividade. 
Logo a alienação é - no sentido marxista destas noções - a ruptura entre a essência e a existência do homem. (Markus, 1974, p.99)

As possibilidades para a existência são dadas pela totalidade das relações sociais, pelo desenvolvimento histórico da produção e das objetivações humanas. Elas não são arbitrárias nem abstratas, mas históricas e concretas. Por isso são possibilidades objetivas de apropriação pelos indivíduos, que definem tanto as possibilidades quanto a alienação.

A possibilidade não é a realidade, mas é, ela também, uma realidade: que o homem possa ou não possa fazer determinada coisa, isto tem importância na avaliação daquilo que ele realmente faz. Possibilidade quer dizer "liberdade". A medida das liberdades entra no conceito de homem. Que existam as possibilidades objetivas de não se morrer de fome, e que, mesmo assim, se morra de fome, é algo que, ao que parece, tem sua importância. (Gramsci, 1999, p.406)

Gramsci coloca de maneira muito clara a questão. A "universalização" do junkie food nada prova em contrário. A necessidade de que ninguém mais morra de fome não diminui com o espanto estadunidense de que estão ficando obesos. Uma e outra são alienações e devem ser superadas. Mas não podemos tomá-las como da mesma ordem. E que ninguém duvide da possibilidade de que não se morra mais de fome! As possibilidades objetivas são possibilidades tanto para a apropriação de mais alienação quanto para sua superação. Mas, como completou Gramsci, "a existência das condições objetivas ou possibilidade, ou liberdade - ainda não é suficiente: é necessário “conhecê-las" e saber utilizá-las. Querer utilizá-las” (ibidem).

\section{A tarefa da educação escolar perante suas contradições}

Dessa forma, buscamos caracterizar as objetivações humanas como ao mesmo tempo universais e contraditórias. Buscar sociali- 
zá-las, e procurar o meio eficaz de garantir a apropriação delas, requer, além de seu reconhecimento, a vontade subjetiva de fazê-lo. Essa socialização pede um posicionamento ante a própria cultura humana. Esse posicionamento deve ser capaz de perceber que a riqueza e a profundidade da análise das características concretas de um certo fenômeno num dado contexto social não pode se realizar em detrimento da reflexão sobre o sentido que esse fenômeno tem no interior do processo histórico maior. Dito de outra forma, deve ser capaz de captar justamente as possibilidades dadas ao processo histórico a partir da análise do desenvolvimento concreto e contraditório do fenômeno.

Assim, as possibilidades objetivas para a superação do capital, da realização de uma sociabilidade livre e universal e de uma produção regida pela produção de coisas úteis, se encontram no desenvolvimento do próprio capitalismo e solicitam um passo adiante: o revolucionamento da própria estrutura que as gerou.

Para Lenin (1977), a tarefa da educação deve ser formar para o comunismo, o que significa dizer, formar para a superação da ordem do capital e para a transformação da realidade social para alcançarmos fins efetivamente humanos. Mas, segue Lenin (1977, p.207), essa formação não pode se dar apenas pela apropriação das insígnias comunistas e das formulações dos especialistas em cultura proletária, ela passa pela apropriação da soma dos conhecimentos acumulados pela humanidade sob o jugo da sociedade capitalista, latifundiária e burocrática. "Seria equivocado pensar que basta aprender as consignas comunistas, as conclusões da ciência comunista, sem assimilar a soma de conhecimentos dos quais é conseqüência o próprio comunismo."

O que se coloca é a impossibilidade de se ensinar qualquer conteúdo que não o formulado no desenvolvimento da sociedade de classes. Não há outras objetivações para apropriarmos que não as criadas nesse desenvolvimento: o da pré-história da humanidade. Pois, ante uma situação de crise, as únicas armas de que dispomos são aquelas fornecidas pela conjuntura, ou seja, as que inventamos.

Querer afastar esse conteúdo por reconhecer nele elemento de alienação é um engodo que na realidade esconde o verdadeiro temor: 
o da apropriação pela classe trabalhadora das potências que o capitalismo liberou, mas que ainda segue se realizando à custa da maioria dos indivíduos. A impossibilidade histórica de que essa apropriação universal se realize no interior do capitalismo evidencia o caráter materialmente determinado não só dos conteúdos do conhecimento, mas também de sua propriedade.

Assim, o ensino-aprendizagem desses conhecimentos, se, por um lado, é necessário para a reprodução do capital, por outro, deve se restringir aos limites do processo de valorização desse. Deve-se fazer em doses homeopáticas, dando somente o necessário para o trabalhador exercer seu papel na divisão social do trabalho, juntamente com a inculcação de um quadro de valores que a legitime, que no mais das vezes se confunde com a própria não difusão do conhecimento.

Gramsci, num comentário sobre a escola tradicional, aponta um caminho para entendermos a questão. Então, diz Gramsci (2001, p.49):

A escola tradicional era oligárquica já que destinada à nova geração dos grupos dirigentes, destinada por sua vez a tornar-se dirigente: mas não era oligárquica pelo seu modo de ensino. Não é a aquisição de capacidades de direção, não é a tendência a formar homens superiores que dá a marca social de um tipo de escola. A marca social é dada pelo fato de que cada grupo social tem um tipo de escola próprio, destinado a perpetuar nestes estratos determinada função tradicional, dirigente ou instrumental.

Noutra passagem de seus cadernos, Gramsci (1999, p.95-6) ajuda-nos ainda mais a por ordem nesta questão, quando diz:

Criar uma nova cultura não significa apenas fazer individualmente descobertas "originais"; significa também, e sobretudo, difundir criticamente verdades já descobertas, "socializá-las" por assim dizer; e, portanto, transformá-las em base de ações vitais, em elemento de coordenação e de ordem intelectual e moral. O fato de que uma multidão de homens seja conduzida a pensar coerentemente e de maneira unitária a realidade presente é um fato "filosófico" 
bem mais importante e "original" do que a descoberta, por parte de um "gênio" filosófico, de uma nova verdade que permaneça como patrimônio de pequenos grupos intelectuais.

Aqui, porém, também não cabe ingenuidade. Quando Saviani (2000, p.17) definiu o trabalho educativo como "ato de produzir, direta e intencionalmente, em cada indivíduo singular, a humanidade que é produzida histórica e coletivamente pelo conjunto dos homens", ele sentiu a necessidade de complementar:

Assim, o objeto da educação diz respeito, de um lado, à identificação dos elementos culturais que precisam ser assimilados pelos indivíduos da espécie humana para que eles se tornem humanos e, de outro lado e concomitantemente, à descoberta das formas mais adequadas para atingir esse objetivo.

Dessa forma, encerramos esse breve esboço afirmando novamente que a alienação presente nos conteúdos é um fardo que a escola, no interior da sociedade capitalista, deve encarar. Reconhecê-lo não pode significar tergiversar sobre seu papel de socialização desses conteúdos, que no mais das vezes não é pura e simplesmente alienação, mas também contém a possibilidade da liberdade (embora, como já dissemos, há objetivações tanto no campo da produção material quanto espiritual em que essa dialética fica reduzida a um dualismo: pura e simples reificação).

Uma análise crítica dessa questão não pode significar um recuo ante as tarefas que se impõe: a de lutar para que a existência de todos os indivíduos se alce ao nível das possibilidades contidas na totalidade das relações sociais. A crítica aos conteúdos da ciência, da arte, da política, da ética não pode significar seu abandono. Se é certo que a superação desses conteúdos, historicamente determinados e limitados pelas contradições que os sustêm, seja condição para que a apropriação signifique diretamente apropriação das forças essenciais humanas, ou seja humanização do indivíduo, não sendo também apropriação da alienação; também é certo que essa superação não 
pode se dar apenas no plano dos próprios conteúdos da ciência, da arte, da política etc. Essa superação pede um passo que a escola não pode dar. Ela não é capaz de superar por si mesma uma contradição da qual ela própria é produto. Mas ela tem seu papel. E se podemos afirmá-lo de maneira taxativa, diríamos que seu papel é o de fazer que "os dominados dominem as armas que os dominantes usam para dominá-los", mesmo que possamos dizer que portar armas não seja abstratamente bom. Romper o cortejo triunfante do qual a própria cultura é a presa para se afastar de um tipo de transmissão que não percebe que sob esse cortejo dos que triunfam jaz a corveia de seus contemporâneos. Fazer emergir esses contemporâneos não apenas para lhes afirmar sua cultura própria, o que também é indispensável, mas para mostrar-lhes sua necessária participação na criação da cultura humana, da qual agora devem apropriar-se. Em suma, romper com a perspectiva burguesa que rompe o vínculo entre o desenvolvimento material e a cultura para integrarmos a história da escola e de seus conteúdos à história da luta de classes, para que assim, não negando suas contradições, mas mergulhando profundamente nelas, possamos escová-la a contrapelo (Benjamin, 1994).

\section{Referências bibliográficas}

ADORNO, T.W.; HORKHEIMER, M. Dialética do esclarecimento. Trad. Guido Almeida. Rio de Janeiro: Jorge Zahar, 1985.

BENJAMIN, W. Sobre o conceito da história. In:_. Magia e técnica, arte e política: ensaios sobre literatura e história da cultura. 7.ed. São Paulo: Brasiliense, 1994. (Obras escolhidas, v.1).

DUARTE, N. A individualidade para-si: contribuição a uma teoria histórico-social da formação do indivíduo. Campinas: Autores Associados, 1993.

Vigotski e o "aprender a aprender": crítica às apropriações neoliberais e pós-modernas da teoria vigotskiana. 3.ed. Campinas: Autores Associados, 2004.

GRAMSCI, A. Cadernos do cárcere: introdução ao estudo da filosofia-a filosofia de Benedetto Crocce. v.I. Rio de Janeiro: Civilização Brasileira, 1999. 
Cadernos do cárcere: os intelectuais. O princípio educativo. Jornalismo. v.II. Rio de Janeiro: Civilização Brasileira, 2001.

HELLER, A. O cotidiano e a história. 4.ed. São Paulo: Paz e Terra, 1992.

LENIN, V. I. Tareas de las organizaciones juveniles. In: Obras escogidas (en doce tomos). Moscú: Progresso, 1977. tomo XI

LUKÁCS, G. Marx e o problema da decadência ideológica. In: Marxismo e teoria da literatura. Rio de Janeiro: Civilização Brasileira, 1968.

MARCUSE, H. A ideologia da sociedade industrial (o homem unidimensional). 4.ed. Rio de Janeiro: Zahar, 1978.

. Sobre o caráter afirmativo da cultura. In: Cultura e sociedade. São Paulo: Paz e Terra, 1997. v.I.

MARKUS, G. A teoria do conhecimento no jovem Marx. Rio de Janeiro: Paz e Terra, 1974.

MARX, K. O capital: crítica da economia política. São Paulo: Abril Cultural, 1983. v.I. Livro primeiro: O processo de produção do capital.

. Elementos fundamentales para la crítica de la economia política (Grundrisse) v.I. México: Siglo Veintiuno, 1987.

Dezoito brumário de Luis Bonaparte. In: MARX, K.; ENGELS, F. Obras escolhidas. São Paulo: Alfa-Ômega, s. d.

MÉSZÁROS, I. O poder da ideologia. São Paulo: Boitempo, 2004. Educação para além do capital. São Paulo: Boitempo, 2005.

SAVIANI, D. Pedagogia histórico-crítica: primeiras aproximações. 7.ed. Campinas: Autores Associados, 2000. 



\section{6 \\ RELAÇÕES ENTRE O DESENVOLVIMENTO INFANTIL E O PLANEJAMENTO DE ENSINO}

Ana Carolina Galvão Marsiglia ${ }^{1}$

\section{O desenvolvimento é espontâneo ou social?}

O pesquisador suíço Jean Piaget se dedicou ao problema do conhecimento: o que é, como o ser humano chega a ele, como se passa de um conhecimento a outro etc. Sua teoria destinava-se a tentar explicar o conhecimento baseando-se na biologia, fazendo um elo entre essa ciência e a filosofia, com dados empíricos. Segundo Azenha (1993, p.8), "a formação típica de cientista leva-o a procurar um suporte experimental para suas especulações filosóficas, de forma a poder construir uma epistemologia de base biológica". Essa autora também afirma que

a concepção piagetiana do funcionamento intelectual inspira-se fortemente no modelo biológico de trocas entre o organismo e o ambiente, fruto de seus estudos biológicos sobre moluscos [...].

1 Graduada em Pedagogia pela Universidade Estadual Paulista (Unesp), campus de Bauru, foi professora de Educação Infantil e Ensino Fundamental e atualmente cursa o doutorado no Programa de Pós-Graduação em Educação Escolar da Unesp, campus de Araraquara, com bolsa da Fundação de Amparo à Pesquisa do Estado de São Paulo (Fapesp). É membro do Grupo de Pesquisa "Estudos marxistas em educação". 
A observação da forma pela qual estes organismos adaptam-se ao ambiente e o assimilam de acordo com sua estrutura levou Piaget a conceber o modelo para o desenvolvimento cognitivo. (ibidem, p.18)

Piaget estabeleceu um modelo evolucionista em seus estudos: as estruturas sofrem alterações constantes, que vão ampliando cada vez mais seus subprodutos para estados qualitativamente superiores.

A cada estágio evolutivo corresponde um tipo de estrutura cognitiva ou modelo de organização da interação do homem com o ambiente. Assim, são também essas estruturas cognitivas as que permitem predições quanto àquilo que é possível conhecer em cada momento da evolução cognitiva. (ibidem, p.24)

Portanto, "a concepção do funcionamento cognitivo em Piagetéa aplicação no campo psicológico de um princípio biológico mais geral da relação de qualquer ser vivo em interação com o ambiente" (ibidem).

Divergindo de Piaget, para quem o ser humano é concebido como um organismo como qualquer outro ser vivo, para a psicologia histórico-cultural, os animais têm suas atividades ligadas às necessidades biológicas, enquanto "o homem é um ser de natureza social, que tudo o que tem de humano nele provém da sua vida em sociedade, no seio da cultura criada pela humanidade" (Leontiev, 1978, p.261).

Na sociedade capitalista, a possibilidade de apropriação de bens culturais, tanto materiais quanto não materiais, não está dada da mesma forma a todos os seres humanos. Segundo Leontiev:

A unidade da espécie humana parece ser praticamente inexistente não em virtude das diferenças de cor da pele, da forma dos olhos ou de quaisquer outros traços exteriores, mas sim das enormes diferenças nas condições e modo de vida, da riqueza da atividade material e mental, do nível de desenvolvimento das formas e aptidões intelectuais. Se um ser inteligente vindo de outro planeta visitasse a Terra e descrevesse as aptidões físicas, mentais e estéticas, as qualidades 
morais e os traços do comportamento de homens pertencentes às classes e camadas sociais diferentes ou habitando regiões e países diferentes, dificilmente se admitiria tratar-se de representantes de uma mesma espécie. Mas esta desigualdade entre os homens não provém das suas diferenças biológicas naturais. Ela é o produto da desigualdade econômica, da desigualdade de classes e da diversidade consecutiva das suas relações com as aquisições que encarnam todas as aptidões e faculdades da natureza humana, formadas no decurso de um processo sócio-histórico. (ibidem, p.274)

Dessa constatação decorre a importância de um posicionamento em defesa da classe trabalhadora para que ela possa ter acesso às conquistas produzidas historicamente pelo trabalho humano, que se objetivam sob a forma de instrumentos da cultura material e intelectual (linguagem, instrumentos, ciência etc.), cuja apropriação é essencial ao desenvolvimento ontogenético e ocorre nas e pelas relações com outros indivíduos. Assim, a criança, em seu desenvolvimento, "não está de modo algum sozinha em face do mundo que a rodeia. As suas relações com o mundo têm sempre por intermediário a relação do homem aos outros seres humanos" (ibidem, p.271-2).

Ao desconsiderar o caráter histórico-social do desenvolvimento humano e apoiar-se em uma matriz biológica, Piaget incorre na naturalização e universalização dos fenômenos humanos. Segundo Duarte (2006b, p.265),

a naturalização dos fenômenos humanos leva qualquer teoria à eternização e à universalização de fenômenos que são históricos e, muitas vezes, decorrentes de determinadas relações sociais alienadas. Piaget não escapa a essa regra. Também não consegue distinguir o que é fruto da alienação do que se tornou parte constitutiva necessária do gênero humano.

De acordo com a psicologia histórico-cultural, a aprendizagem não deve orientar-se pelas demandas espontâneas do sujeito e nem deve manter-se à espera de uma maturidade biológica que possibilite 
aprender. Ao contrário, o ensino deve tomar como ponto de partida a zona de desenvolvimento próximo e transformá-la em desenvolvimento real, qualificando a aprendizagem como aquela que vai possibilitar a efetivação das funções psicológicas superiores como funções internalizadas, ou seja, funções intrapsíquicas que assim se constituíram a partir de funções interpsíquicas. Daí a afirmação de que "o único bom ensino é o que se adianta ao desenvolvimento" (Vigotski, 2006, p.114).

Partindo da tese vigotskiana de que a aprendizagem precede o desenvolvimento, o planejamento de ensino deve, então, ser elaborado de maneira a fazer progredir o indivíduo. Como? Por meio de ações pedagógicas que garantam a apropriação da cultura universal, identificando os elementos culturais que, ao serem assimilados, produzam a humanização nos sujeitos singulares (Saviani, 2003).

Os elementos culturais referidos, entretanto, serão incluídos ou não no planejamento, a partir de qual critério? Distinguindo aquilo que é clássico; aquilo que perdurou ao tempo porque permanece como essencial, como referência ao mundo em que vivemos e fundamental para se compreender o atual estágio de desenvolvimento em que nos encontramos. (ibidem). Esse deve ser o guia do planejamento escolar e aqui reside uma das principais diferenças entre as pedagogias do "aprender a aprender" ${ }^{2}$ e a pedagogia histórico-crítica, posto que para a primeira o ensino deve dirigir-se pelos interesses espontâneos do aluno, conforme veremos a seguir.

\section{Qual o papel da escola?}

Gramsci (1982) escreveu em sua obra Os intelectuais e a organização da cultura que a escola deveria lutar contra o folclore e ensinar

2 As pedagogias do "aprender a aprender" pertencem à mesma matriz teórica do escolanovismo, centrando-se no aluno e na aprendizagem que atenda seus interesses espontâneos, bem como focalizando os processos e não o produto, isto é, concentrando-se em "aprender a aprender", tendo papel secundário o que se aprende (Duarte, 2006b). 
de maneira que os alunos aprendessem que a sociedade é estabelecida pelo homem e pode ser modificada por ele, o que só é possível com conhecimentos que superem o senso comum. Ao referir-se à imprensa, assevera esse autor que

a informação científica deveria ser parte integrante de qualquer jornal italiano, seja como noticiário científico-tecnológico, seja como exposição crítica das hipóteses e opiniões científicas mais importantes [...]. Um jornal popular, mais do que os outros, deveria ter essa seção científica, a fim de controlar e dirigir a cultura de seus leitores, que possui elementos de "bruxaria" ou é fantástica, e para "desprovincianizar” as noções correntes. (ibidem, p.201)

Por essa afirmação, transposta ao contexto escolar, elucida-se que o papel da escola na perspectiva marxista deve ser de superar a mistificação dos fenômenos ao dominar aquilo que de mais desenvolvido a humanidade produziu, pois nesses conhecimentos estão cristalizadas as qualidades humanas de maior riqueza e que encaminharão o indivíduo ao seu maior desenvolvimento.

Para a pedagogia histórico-crítica e a psicologia histórico cultural, a escola como instituição social é fundamental ao desenvolvimento psíquico da criança por sua função e representatividade na sociedade, pois

as aquisições do desenvolvimento histórico das aptidões humanas não são simplesmente dadas aos homens nos fenômenos objetivos da cultura material e espiritual que os encarnam, mas são aí apenas postas. Para se apropriar destes resultados, para fazer deles as suas aptidões, "os órgãos da sua individualidade", a criança, o ser humano, deve entrar em relação com os fenômenos do mundo circundante através de outros homens, isto é, num processo de comunicação com eles. Assim, a criança aprende a atividade adequada. Pela sua função este processo é, portanto, um processo de educação. (Leontiev, 1978, p.272)

Piaget (1998c, p.42), por sua vez, apresenta-se como defensor de uma escola espontaneísta, que tenha o mínimo possível de interferên- 
cia do professor e de qualquer tipo de transmissão que, por exemplo, organize o currículo escolar. Diz o pesquisador suíço: "A 'escola ativa' baseia-se na idéia de que as matérias a serem ensinadas à criança não devem ser impostas de fora, mas redescobertas pela criança por meio de uma verdadeira investigação e de uma atividade espontânea".

Para Piaget, a escola tradicional obrigava a criança a aproximar o professor do aluno: apropriarem-se das mesmas noções. Mas isso, na visão piagetiana, seria um equívoco, pois a criança deveria basear-se em suas experiências, e seu desenvolvimento está atrelado a aspectos biológicos. Isso se esclarece quando Piaget (1998d, p.173) explicita que "o pensamento da criança (não mais, aliás, do que o do adulto) não pode jamais ser tomado em si mesmo e independente do meio", e declara que a criança dará respostas diferentes para questões semelhantes conforme seu meio social, mas reafirma traços comuns a todas as crianças, que indicariam seus estágios de desenvolvimento. Assim, apesar de julgar que os métodos de ensino podem "aumentar o rendimento dos alunos e ao mesmo tempo acelerar seu crescimento espiritual sem prejudicar sua solidez" (ibidem, p.176), o pesquisador suíço sublinha dois fatores que interferem no desenvolvimento e que ao mesmo tempo são seus produtores: a existência de uma evolução mental (que deve adequar o alimento intelectual de cada idade) e a importância de se levar em conta interesses e necessidades. Sendo assim, os métodos e as ações docentes se tornam acessórias ao desenvolvimento espontâneo.

Se levarmos em conta os pressupostos piagetianos, pouco se pode planejar no ensino. Se a escola deve seguir as descobertas da criança, como então poderia ser feito um plano de ações pedagógicas? Advém dessa contraditoriedade que a escola se envolva nos "conteúdos" cotidianos em detrimento do conhecimento universal, pois assim estariam voltados aos interesses "naturais" do aluno.

Não são poucos os livros didáticos e materiais de orientação para professores que destacam a relevância do educador trabalhar a disciplina de ciências a partir de projetos sobre a dengue ou leshimaniose, a disciplina de História por meio da história de vida do aluno e assim por diante. Pouco se avança dessa forma. Há que cuidar para que, 
ao "contextualizar" os conteúdos, não se esteja indicando privilegiar esse tipo de trabalho em detrimento do currículo. Podemos discorrer sobre dois aspectos importantes da questão do currículo, que devem orientar o planejamento de ensino. O primeiro ponto pode ser definido como a diferença entre curricular e extracurricular, e o segundo, intimamente relacionado ao primeiro, refere-se ao debate sobre quais os conteúdos que a escola deve garantir na educação escolar, ou seja, o que de fato importa a escola transmitir?

Ao analisar a diferença entre curricular e extracurricular, podemos recorrer a Saviani (2003) quando explica que currículo relaciona-se às atividades nucleares da escola. E o que é central na escola? A transmissão e assimilação do saber sistematizado, viabilizado pela organização de sua dosagem e sequência em um determinado tempo, que permitam ao aluno dominar os conhecimentos. Sendo assim, o autor destaca que a escola não pode perder de vista essa sua função, pois pode incorrer na inversão de suas prioridades, perdendo sua especificidade. Para ilustrar essa situação ele afirma:

Exemplo disso são as comemorações nas escolas, que se espalhavam por todo o ano letivo, às quais agora se associam, ou a elas são acrescidos, os denominados temas transversais, como educação ambiental, educação sexual, educação para o trânsito etc. Ao final do ano letivo, após todas essas atividades, fica a questão: as crianças foram alfabetizadas? Aprenderam português? Aprenderam matemática, ciências naturais, história, geografia? Ora, estes são os elementos clássicos do currículo escolar, tão clássicos que ninguém contesta. [...] No entanto, esses elementos acabam por ser secundarizados, diluídos numa concepção difusa de currículo. [...] [Atividades como as comemorações] não sendo essenciais, definem-se como extracurriculares. Nesta condição, elas só fazem sentido quando enriquecem as atividades curriculares, não devendo, em hipótese alguma, prejudicá-las ou substituí-las. (ibidem, p.102)

O segundo ponto que propomos discutir em relação ao currículo é: afinal, o que a escola deve transmitir? De acordo com Duarte 
(2006a), há quem argumente que a escola pública (que atende a classe trabalhadora) não deveria transmitir a ciência e a arte burguesas porque isso invadiria a consciência da classe trabalhadora de forma colonizadora. Esse autor discorda desse argumento, pois entende que

o fato de boa parte da produção científica e artística terem sido apropriadas pela burguesia, transformando-se em propriedade privada e tendo seu sentido associado ao universo material e cultural burguês, não significa que os conhecimentos científicos e as obras artísticas sejam inerentemente burgueses. (ibidem, p.615)

Há, ainda, o que, por um lado, se configura em preconceito e, por outro, em idealização romântica na consideração de que a classe trabalhadora seria colonizada. Isso significaria a incapacidade da classe trabalhadora de atribuir um novo significado ao conhecimento do qual se apropria, bem como seria idealismo acreditar que "existe um cotidiano no qual a cultura popular existe sem a intervenção colonizadora da cultura burguesa" (ibidem, p.615). Conforme já foi afirmado anteriormente, cabe à educação escolar proporcionar a apropriação do que há de mais desenvolvido na cultura humana, que tenha sido produzido pelo capitalismo e suas contradições ou não. Só a partir do domínio da riqueza cultural humana é que poderemos superar o capitalismo em direção a uma sociedade comunista.

\section{Que função tem o professor?}

Duarte (2003) indica que a formação de professores sob a óptica das pedagogias do "aprender a aprender" está centrada na reflexão sobre a própria prática, de acordo com a valorização do conhecimento cotidiano e preocupada com os processos pelos quais se adquire o conhecimento, não importando qual conhecimento se está adquirindo. Dentro desses pressupostos, a formação dos educadores não necessitaria de estudos sólidos e aprofundados, levando-os a atuarem com seus alunos sobre as mesmas bases que foram formados: 
superficiais e pragmáticas. Como ainda assevera Duarte (1998), apesar do construtivismo (e podemos constatar isso de forma geral nas pedagogias do "aprender a aprender") afirmar a importância do papel do professor, isso acaba por se diluir no processo educativo, tornando o educador aquele que acompanha, orienta, propõe ao aluno, mas cujas ações têm menor valor do que aquilo que o aluno aprende sozinho (Duarte, 2008).

Na perspectiva marxista, às funções psicológicas elementares, garantidas pela evolução da espécie, somam-se as funções psicológicas superiores:

produzidas na história de cada indivíduo particular, dependentes, portanto, de suas condições de vida e de aprendizagens. As funções superiores, exclusivamente humanas, não são produtos de uma estrutura psíquica natural, estática e aistórica, mas sim correspondentes a situações de desenvolvimento que não são sempre as mesmas para um dado indivíduo e muito menos para diferentes indivíduos, especialmente enquanto representantes de classes sociais desiguais. (Martins \& Arce, 2007, p.54)

Se as funções psicológicas superiores se desenvolvem por meio da apropriação da cultura, há necessidade daquele que tem domínio do patrimônio humano-genérico para transmitir às novas gerações aquilo que o desenvolvimento humano lhes garantiu ao longo de sua história, produzindo desenvolvimento psicológico fundamental ao sujeito e sua constituição psicofísica. Nesse sentido, afirma Saviani (2003, p.144) que

o professor, enquanto alguém que, de certo modo, apreendeu as relações sociais de forma sintética, é posto na condição de viabilizar esta apreensão [dos conhecimentos] por parte dos alunos, realizando a mediação entre o aluno e o conhecimento que se desenvolveu socialmente.

Exemplo disso encontramos no texto Diferenças culturais de pensamento, no qual Luria (2006) apresenta experimentos realizados 
com adultos com diferentes níveis de instrução e mostra que o pensamento prático (associado à experiência imediata do sujeito) evolui e é superado pelo pensamento teórico na medida em que o indivíduo avança em sua escolaridade.

Em contraposição a essa abordagem, Piaget, em texto sobre a educação moral, mas a partir do qual é possível estender suas declarações à escola em geral, questiona a importância do conteúdo e do professor no processo de ensino e aprendizagem, caracterizando ambos como complementos à atividade espontânea do aluno, que deve sofrer o mínimo de interferência e ter como objetivo principal "aprender a aprender".

Devemos confessar que uma conversação organizada em torno das redações das crianças ou dos fatos da história, da geografia e da literatura é capaz de fundir-se muito melhor com as preocupações do aluno e de mostrar-se, assim, mais vantajosa que um ensinamento sistemático e isolado de moral. Mas isto depende unicamente de quanta atividade se concede às crianças na preparação das conversações. (Piaget, 1998c, p.41)

O pesquisador suíço entendia que somos resultado da educação que recebemos. Mas ao assegurar que "a criança reage sempre da mesma maneira a certas situações sociais” (Piaget, 1998a, p.104), deixa saliente sua compreensão biologizante do ser humano, segundo a qual a aprendizagem vai a reboque do desenvolvimento, o que se contrapõe ao posicionamento sócio-histórico, como já foi afirmado anteriormente.

A escola deve garantir acesso às formas mais desenvolvidas do saber objetivo. Diante do relativismo cultural postulado pelo pós-modernismo, ${ }^{3}$ diferentes saberes coabitariam em lugar de formas de conhecimento mais desenvolvidas do que outras (Duarte, 2006a). Qualé o saber mais desenvolvido? É possível definir um saber como

3 O referencial pós-moderno deriva de diversas filosofias tendo como característica a negação da realidade e, por conseguinte, do conhecimento. Com isso, defendem seus representantes a impossibilidade de conhecer a realidade e constatá-la como universal (Duarte, 2006a). 
mais desenvolvido do que outro? Essa é uma dificuldade contemporânea, advinda da difusão das ideias pós-modernas, céticas em relação à história humana e que descartam os parâmetros que nos permitem dizer que um saber é mais desenvolvido do que outro. Como já afirmou Newton Duarte no Capítulo 2 deste livro, será que nós acreditaríamos que a ideia de que o Sol gira em torno da Terra é apenas diferente da afirmação científica de que é a Terra que gira em torno do Sol? Não. Nós sabemos, por meio da ciência, que há uma resposta verdadeira e outra não e que, portanto, não se pode relativizar essa resposta. Para Duarte (2008), trata-se de uma ilusão com finalidade de reprodução ideológica do capitalismo a ideia de que a realidade é apenas uma elaboração subjetiva na qual é possível negociar significados em função de uma ou outra convenção cultural. Pensar o currículo da escola, portanto, está intrinsecamente relacionado à relevância dos conteúdos que constituirão o planejamento de ensino de cada disciplina: quais serão, como serão distribuídos e abordados. Para Saviani (2008, p.45),

os conteúdos são fundamentais e sem conteúdos relevantes, conteúdos significativos, a aprendizagem deixa de existir, ela transforma-se num arremedo, ela transforma-se numa farsa [...]. A prioridade de conteúdos é a única forma de lutar contra a farsa do ensino. Por que esses conteúdos são prioritários? Justamente porque o domínio da cultura constitui instrumento indispensável para a participação política das massas [...]. O dominado não se liberta se ele não vier a dominar aquilo que os dominantes dominam. Então, dominar o que os dominantes dominam é condição de libertação.

\section{A atividade de estudo}

A criança, ao entrar na escola, já possui uma série de aprendizagens que Vigotski denomina "pré-história da aprendizagem”. No entanto, "a existência dessa pré-história da aprendizagem escolar não implica uma continuidade direta entre duas etapas do desenvolvimento" (Vigotski, 2006, p.109). 
O estudo exige uma nova postura do indivíduo, que não é espontânea. Gramsci (1982, p.133) afirma a necessidade de se adquirir procedimentos que levem os estudantes a contrair "hábitos de diligência, de exatidão, de compostura mesmo física, de concentração psíquica em determinados assuntos, que não se pode adquirir senão mediante uma repetição mecânica de atos disciplinados e metódicos". A atividade de estudo, entendida pela psicologia histórico-cultural como atividade principal a partir dos 6-7 anos e que se estende como tal até a adolescência, desencadeia o desenvolvimento intelectual da criança, que decorre da aprendizagem sistematizada de conteúdos, que elevam o grau de pensamento abstrato e complexificam as operações mentais (Lazaretti, 2008, p.208).

Tolstij (1989), baseando-se em Elkonin, assinala que a atividade de estudo é social por seu conteúdo (nela tem lugar a assimilação da cultura humana), por seu sentido (é socialmente significativa e valorizada) e por sua realização (se efetua em concordância com as normas socialmente estabelecidas). Assim, ainda segundo esse autor, a vida escolar solicita da criança a atitude de controlar seu comportamento para atender às demandas do caráter produtivo do estudo e a capacidade de subordinar seus resultados às finalidades conscientemente planejadas.

Na perspectiva piagetiana, a criança sofreria coerção de pais e professores, que por seu prestígio, a levariam a aceitar incondicionalmente suas posições de adultos. Essa coerção repousaria sobre a escola tradicional, impedindo a espontaneidade e consequentemente, o desenvolvimento (Piaget, 1998a). Para esse autor, o grupo (outras crianças) teria muito mais a contribuir do que o professor. Nesse sentido, ele alega que o professor teria dificuldade em atender a todos (então o problema não estaria na ação do professor em si) e atrapalharia a confiança do aluno em si mesmo, ocasionando ou sedimentando suas dificuldades.

Muito freqüentemente, com efeito, o mau aluno que não consegue ceder diante do professor (porque o amor próprio da criança está comprometido, porque a fonte de sentimento de inferioridade 
é o adulto, ou por qualquer outra razão) vê-se tão naturalmente requisitado num grupo de trabalho que suas inibições desaparecem pouco a pouco. (Piaget, 1998b, p.147)

Numa abordagem de preponderância biológica, deixa-se a criança à sua própria sorte, impedindo que a escola exerça sobre ela papel de destaque em sua formação intelectual. Na escola defendida por Piaget, a escola ativa, não se suprime a aula "mas a reduz a um papel mais modesto de respostas às perguntas que o aluno se formula" (ibidem, p.139), enquanto para a concepção histórico-social, as relações interpsíquicas é que propiciarão as relações intrapsíquicas e o parceiro privilegiado da aprendizagem é o professor.

A entrada da criança na escola representa uma mudança muito significativa em sua vida. A partir de então ela começa a cumprir uma atividade socialmente importante. Se antes seus pais julgavam que poderiam interferir em suas brincadeiras, agora a postura se altera e a "hora de estudo" da criança passa a ser respeitada e não é interrompida. Também se nota essa transformação quando, ao pedir um brinquedo, seus pais podem negá-lo, mas não terão a mesma atitude diante do pedido de um lápis ou um caderno (Tolstij, 1989). Vale a pena, entretanto, mencionar que no contexto da sociedade atual, pós-moderna, neoliberal e altamente influenciada pelas pedagogias do "aprender a aprender", muitos pais consideram que não devem "forçar" seus filhos e com isso, ao suporem um pretenso respeito ao "tempo" da criança, acabam por sonegar-lhes um importante papel no desenvolvimento. Deve-se ressaltar também que essa postura é vista de forma oposta pelo construtivismo (variante das pedagogias do "aprender a aprender") e pela pedagogia histórico-crítica. Liliana Tolchinski (1998, p.113), ao defender o construtivismo e tratar da resistência dos pais aos procedimentos livres e espontâneos dessa concepção, afirma:

Os adultos com menor grau de escolaridade, que geralmente ficam fora das sucessivas "renovações pedagógicas", transmitem uma imagem mais rígida da cultura escolar. São os grupos de pais 
que mais se opõem à diminuição da disciplina escolar, à redução das lições de casa, à flexibilização das pautas de avaliação ou falta de correção severa dos erros de ortografia.

Já Dermeval Saviani (2008, p.40), principal representante da teoria marxista em educação, em seu livro Escola e democracia assim se posiciona:

Os pais das crianças pobres têm uma consciência muito clara de que a aprendizagem implica a aquisição de conteúdos mais ricos, têm uma consciência muito clara de que a aquisição desses conteúdos não se dá sem esforço, não se dá de modo espontâneo; conseqüentemente, têm uma consciência muito clara de que para se aprender é preciso disciplina e, em função disso, eles exigem mesmo dos professores a disciplina.

Finalmente, analisemos um excerto de Gramsci (1966, p.13-14):

Se é verdade que toda linguagem contém os elementos de uma concepção do mundo e de uma cultura, será igualmente verdade que, a partir da linguagem de cada um, é possível julgar da maior ou menor complexidade a sua concepção de mundo. Quem fala somente o dialeto e compreende a língua nacional em graus diversos, participa necessariamente de uma intuição do mundo mais ou menos restrita e provinciana; fossilizada, anacrônica em relação às grandes correntes de pensamento que dominam a história mundial. Seus interesses serão restritos, mais ou menos corporativos ou economicistas, não universais. Se nem sempre é possível aprender outras línguas estrangeiras a fim de colocar-se em contato com vidas culturais diversas, deve-se pelo menos conhecer bem a língua nacional. Uma grande cultura pode traduzir-se na língua de outra grande cultura, isto é, uma grande língua nacional historicamente rica e complexa pode traduzir qualquer outra grande cultura, ou seja, ser uma expressão mundial. Mas, com um dialeto, não é possível fazer a mesma coisa. 
Criar uma nova cultura não significa apenas fazer individualmente descobertas "originais"; significa também, e sobretudo, difundir criticamente verdades já descobertas, "socializá-las" por assim dizer; transformá-las, portanto, em base de ações vitais, em elemento de coordenação e de ordem intelectual e moral. $\mathrm{O}$ fato de que uma multidão de homens seja conduzida a pensar coerentemente e de maneira unitária a realidade presente é um fato "filosófico" bem mais importante e "original" do que a descoberta, por parte de um "gênio filosófico", de uma nova verdade que permaneça como patrimônio de pequenos grupos intelectuais.

Esse trecho destaca a necessidade de desenvolvimento da linguagem para a superação dos limites das objetivações "em-si", ${ }^{4}$ contrapondo-se à visão das pedagogias do "aprender a aprender", que situam a linguagem no campo das representações de cada grupo social. Por detrás do discurso do respeito às particularidades de cada grupo, condicionam-se os sujeitos a um ensino que não contribui para que os indivíduos se aproximem das objetivações "para-si". Isso pode ser visto, por exemplo, em material da Secretaria de Estado da Educação do Estado de São Paulo (1983, p.8), que vem adotando o construtivismo como concepção pedagógica há mais de 25 anos:

A alfabetização é um processo, que não se esgota na 1ํㅗㄹérie, no simples reconhecimento e uso de sinais gráficos, mas, se estende pelas séries do $1^{\circ}$ grau, na apreensão do mundo que se revela em signos, no respeito à expressão do indivíduo, que se manifesta em

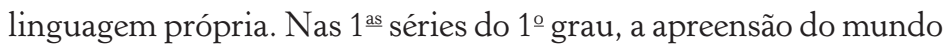
se faz pela linguagem oral e a aquisição da leitura e da escrita deve

4 Segundo a teoria da vida cotidiana desenvolvida por Agnes Heller, as objetivações historicamente produzidas pela atividade social humana estruturam-se em dois níveis principais. Um é o das objetivações em-si que são próprias à esfera da vida cotidiana como é o caso dos objetos e dos usos e costumes. O outro é a das objetivações para-si, as quais adquirem uma relativa autonomia em relação à vida cotidiana e, ao mesmo tempo, a superam, como, por exemplo, a ciência, a arte e a filosofia (Duarte, 1999). 
ser a extensão desse mundo, e não a apresentação de um novo mundo que pouco diz ao indivíduo, ou pior ainda, que deve sobrepor-se ao dele ou até anulá-lo.

Ao fazer a defesa do respeito à linguagem do indivíduo, a concepção construtivista afirma que a realidade não deve ser considerada una. É como se fosse possível cada um ter a sua realidade e, da mesma maneira, a sua forma de expressão de linguagem. Se cada sujeito tem a sua realidade, a sua verdade, o conhecimento acaba por perder sua identidade universal, como defendeu Gramsci. O indivíduo só poderá então adaptar a sua realidade ao mundo como ele o vê. Esse será o processo de conhecimento: a adaptação do mundo aos próprios olhos e adaptação do "olhar" às exigências circunstanciais do cotidiano. As implicações dessa visão ao processo de alfabetização não são poucas. A transformação da aquisição da leitura e da escrita como algo individual impede o sujeito de ascender às formas mais desenvolvidas da cultura, nesse caso, as formas mais elaboradas da linguagem, e com isso inviabiliza-se o processo de humanização plena dos indivíduos. Faz-se necessária a apropriação sistematizada dos conceitos científicos, que incorporam por superação os conceitos espontâneos.

Para Vigotski (2009), os conceitos espontâneos e científicos se influenciam mutuamente, mas se comportam diferentemente em tarefas idênticas, pois se formam, desenvolvem e dizem respeito a processos diversos. Afirma esse autor que a apreensão dos conceitos científicos depende da aprendizagem, que tem "poderosa força orientadora" na formação dos conceitos. Isso porque os conceitos científicos ensinam aquilo que a criança não tem diante dos olhos, que vai além de sua experiência. Para clarificar essa diferença, Vigotski (2009, p.264) compara a formulação da criança para a lei de Arquimedes ${ }^{5}$ e o conceito de irmão.

5 O princípio de Arquimedes: todo corpo mergulhado total ou parcialmente num fluído recebe uma impulsão vertical, de baixo para cima, com intensidade equivalente ao peso do fluído deslocado pelo corpo. Fonte: $<$ http:// pt.wikipedia.org/wiki/Princ\%C3\%ADpio_de_Arquimedes $>$. Por exemplo, 
É amplamente conhecido o fato de que a criança formula melhor o que é a lei de Arquimedes do que o que é irmão. Isto pode decorrer do fato de que os conceitos percorreram caminhos diferentes em seu desenvolvimento. A criança assimila o conceito sobre a lei de Arquimedes de modo diferente do que assimila o conceito de irmão. Ela sabia o que era irmão, e no desenvolvimento desse conceito percorreu muitos estágios antes que aprendesse a definir essa palavra, se é que alguma vez na vida se lhe apresentou essa oportunidade. $\mathrm{O}$ desenvolvimento do conceito de irmão não começou pela explicação do professor nem pela formulação científica do conceito. Em compensação, esse conceito é saturado de uma rica experiência pessoal da criança. Ele já transcorreu uma parcela considerável do seu caminho de desenvolvimento e, em certo sentido, já esgotou o conteúdo puramente fatual e empírico nele contido. Mas é precisamente estas últimas palavras que não podem ser ditas sobre o conceito da lei de Arquimedes.

Sendo assim, trabalhar visando alcançar a elaboração de conceitos científicos relaciona-se a superar as ações voltadas ao imediatamente observável, às necessidades instantâneas etc. As pedagogias do "aprender a aprender" não dão destaque aos conceitos científicos porque se voltam à aparência e não à essência, ao fragmento e não à totalidade, à deferência ao entorno do aluno e o prestígio ao particular em lugar do universal. Já para Saviani (2003, p.15):

A escola existe, $[\ldots]$ para propiciar a aquisição dos instrumentos que possibilitam o acesso ao saber elaborado (ciência), bem como o próprio acesso aos rudimentos desse saber. As atividades da escola básica devem organizar-se a partir dessa questão. Se chamarmos isso de currículo, poderemos então afirmar que é a partir do saber sistematizado que se estrutura o currículo da escola elementar.

se colocarmos em uma balança dois recipientes com a mesma quantidade de água e em um deles mergulharmos um peso de metal, o recipiente que recebeu o peso terá o escoamento do excesso de água, e a balança continuará equilibrada. 
Ora, o saber sistematizado, a cultura erudita, é uma cultura letrada. Daí que a primeira exigência para o acesso a esse tipo de saber seja aprender a ler e escrever. Além disso, é preciso conhecer também a linguagem dos números, a linguagem da natureza e a linguagem da sociedade. Esta aí o conteúdo fundamental da escola elementar: ler, escrever, contar, os rudimentos das ciências naturais e das ciências sociais (história e geografia humanas).

O planejamento de ensino que privilegia aquilo que Saviani (2003) definiu como o currículo da escola elementar precisa ter como horizonte a qualidade daquilo que se planeja e as ações que podem subsidiar seus objetivos da maneira mais zelosa para seu atendimento. Os fundamentos da pedagogia histórico-crítica nos guiam para uma proposta didático-metodológica que subsidia um planejamento de ensino que supere as limitações das proposições das escolas Tradicional e Nova.

Quando Saviani (2003, p.13) destaca que a natureza do trabalho educativo corresponde a um trabalho não material, produtor de ideias, valores, princípios, símbolos, conceitos etc. e que sua especificidade "é o ato de produzir, direta e intencionalmente, em cada indivíduo singular, a humanidade que é produzida histórica e coletivamente pelo conjunto dos homens", estabelece a necessidade de se analisar seu objeto, que "diz respeito, de um lado, à identificação dos elementos culturais que precisam ser assimilados pelos indivíduos da espécie humana para que eles se tornem humanos e, de outro lado e concomitantemente, à descoberta das formas mais adequadas para atingir esse objetivo".

Nessa perspectiva, o planejamento de ensino tem que ter a prática social como ponto de partida da prática educativa, problematizando a prática social global, oferecendo os instrumentos necessários para que o aluno alcance uma visão sintética do conhecimento, permitindo-lhe analisar de maneira mais complexa a prática social, que, não será mais tal e qual aquela que se efetivava no ponto de partida, pois agora ela conta com o avanço propiciado pelas mediações teóricas de análise dos fenômenos (Saviani, 2008). 


\section{Considerações finais}

Na perspectiva teórica da pedagogia histórico-crítica e da psicologia histórico-cultural, faz-se premente uma educação escolar de qualidade desde a Educação Infantil, rica em possibilidades e intervenções que possibilitem aos indivíduos a apropriação da cultura em suas formas mais desenvolvidas. Trata-se de ter, como afirmou Duarte (1998), uma concepção afirmativa pelo ato de ensinar, que se adiante ao desenvolvimento, contribuindo no processo de humanização dos indivíduos. Essa tarefa, cada vez mais problemática na sociedade atual, precisa ser enfrentada pelos educadores, radicalizando a luta em defesa da educação, contra as concepções antiescolares, isto é, "contra todas as políticas, as práticas e os ideários que apresentam como uma educação que valorizaria a autonomia do aluno algo que, na realidade, é um intenso processo social de apropriação privada do conhecimento" (ibidem, p.205).

Essa luta começa, em termos pedagógicos, no planejamento de ensino. $\mathrm{O}$ ato de planejar tem sido desvalorizado porque cada vez menos se pode planejar diante da hegemonia do "aprender a aprender".

Crítica recorrente dessas pedagogias da atualidade é a de que os professores copiam seus planos de ensino de um ano para o outro somente para cumprir uma exigência burocrática, ficando engavetados sem que sirvam verdadeiramente como orientação das práticas pedagógicas. Esse posicionamento que critica a falta de "dinamismo" do professor se coaduna com as concepções pós-modernas e neoliberais, em que tudo é descartável, fugaz e imediato.

Os conteúdos universais que devem balizar o currículo e, portanto, os planos de ensino precisam repetir os mesmos conteúdos (com as devidas alterações que se façam necessárias diante do movimento histórico de constituição da ciência). Afinal, a escola vai mudar o conhecimento clássico ano a ano? Se for assim, não é clássico, de acordo com aquilo que se explicou anteriormente. Por sua vez, não há, por parte da pedagogia histórico-crítica um posicionamento de estagnação em relação aos conteúdos e seu planejamento, mas sim uma preocupação em garantir o desenvolvimento dos indivíduos de forma abrangente, o que, no atual desenvolvimento societário que 
temos, se traduz na apropriação de conhecimentos dos quais ainda estamos bem distantes. A riqueza dos conteúdos clássicos demanda, incontestavelmente, definições e redefinições dos modos pelos quais deva ser transmitido, e nisso reside a importância, sempre presente, do planejamento de ensino.

O primeiro passo que temos que dar é sair do romantismo e da sedução dos discursos das pedagogias do "aprender a aprender" para ingressar em uma nova etapa, na qual o máximo desenvolvimento dos seres humanos se imponha como referência dos planejamentos de ensino, com valorização do professor e da educação escolar como forma mais desenvolvida de apropriação da cultura.

\section{Referências bibliográficas}

AZENHA, M. G. Construtivismo: de Piaget a Emília Ferreiro. São Paulo: Ática, 1993.

DUARTE, N. Concepções afirmativas e negativas sobre o ato de ensinar. Caderno CEDES, v.19, n.44, p.85-106, 1998.

. A individualidade para-si: contribuição a uma teoria histórico-social da formação do indivíduo. 2. ed. Campinas: Autores Associados, 1999.

. Conhecimento tácito e conhecimento escolar na formação do professor (por que Donald Schön não entendeu Luria). Educação e Sociedade, Campinas, v.24, n.83, p.601-25, agosto, 2003.

. A contradição entre universalidade da cultura humana e o esvaziamento das relações sociais: por uma educação que supere a falsa escolha entre etnocentrismo ou relativismo cultural. Educação e Pesquisa. São Paulo, v.32, n.3, p.607-18, set./dez. 2006a.

. Vigotski e o "aprender a aprender": crítica às apropriações neoliberais e pós-modernas da teoria vigotskiana. 4.ed. Campinas: Autores Associados, 2006b.

Por que é necessária uma análise crítica marxista do construtivismo? In: LOMBARDI, J. C.; SAVIANI, D. (Org.) Marxismo e educação: debates contemporâneos. 2.ed. Campinas: Autores Associados; HISTEDBR, 2008. p.203-21.

GRAMSCI, A. Concepção dialética da história. Rio de Janeiro: Civilização Brasileira, 1966.

Os intelectuais e a organização da cultura. 4.ed. Rio de Janeiro: Civilização Brasileira, 1982. 
LAZARETTI, L. M. Daniil Borisovich Elkonin: um estudo das idéias de um ilustre (des)conhecido no Brasil. Assis, 2008. Dissertação (Mestrado)Faculdade de Filosofia e Letras, Universidade Estadual Paulista "Julio de Mesquita Filho".

LEONTIEV, A. O desenvolvimento do psiquismo. Lisboa: Livros Horizonte, 1978.

LURIA, A. R. Diferenças culturais de pensamento. In: VIGOTSKI, L. S.; LURIA, A. R.; LEONTIEV, A. N. Linguagem, desenvolvimento e aprendizagem. 10.ed. São Paulo: Ícone, 2006. p.39-58.

MARTINS, L. M.; ARCE, A. A educação infantil e o ensino fundamental de 9 anos. In: (Org.) Quem tem medo de ensinar na educação infantil?: em defesa do ato de ensinar. Campinas: Alínea, 2007. p.37-62.

PIAGET, J. A evolução social e a pedagogia nova. In: Sobre a pedagogia: textos inéditos. Org. e introd. S. Parrat-Dayan e A. Tryphon. São Paulo: Casa do Psicólogo, 1998a. p.97-111.

Observações psicológicas sobre o trabalho em grupo. In:

Sobre a pedagogia: textos inéditos. Org. e introd. S. Parrat-Dayan e A. Tryphon. São Paulo: Casa do Psicólogo, 1998b. p.137-51.

. Os procedimentos da educação moral. In: Sobre a pedagogia: textos inéditos. Org. e introd. S. Parrat-Dayan e A. Tryphon. São Paulo: Casa do Psicólogo, 1998c. p.25-58.

. Psicologia e pedagogia. Rio de Janeiro: Forense Universitária, 1998d. SÃO PAULO (ESTADO) Secretaria de Educação. Projeto "Capacitação de recursos humanos para o ensino de $1^{\circ}$ grau" (Treinamento: Formação de monitores de alfabetização). Coordenadoria de Estudos e Normas Pedagógicas. São Paulo: SE/CENP, 1983.

SAVIANI, D. Pedagogia histórico-crítica: primeiras aproximações. 8.ed. Campinas: Autores Associados, 2003.

Escola e democracia. 40.ed. (comemorativa). Campinas: Autores Associados, 2008.

TOLCHINSKY, L. Construtivismo em educação: consensos e disjuntivas. In: RODRIGO, M. J.; ARNAY, J. Domínios do conhecimento, prática educativa e formação de professores - A construção do conhecimento escolar. São Paulo: Ática, 1998. v.2, p.103-23.

TOLSTIJ, A. El hombre y la edad. Moscou: Progresso, 1989.

VIGOTSKI, L. S. Aprendizagem e desenvolvimento intelectual na idade escolar. In: VIGOTSKI, L. S.; LURIA, A. R.; LEONTIEV, A. N. Linguagem, desenvolvimento e aprendizagem. 10.ed. São Paulo: Ícone, 2006. p.103-17.

A construção do pensamento e da linguagem. 2.ed. São Paulo: WMF Martins Fontes, 2009. 



\section{7 \\ A ARTE E A FORMAÇÃO HUMANA: IMPLICAÇÕES PARA O ENSINO DE LITERATURA}

Nathalia Botura de Paula Ferreira ${ }^{1}$

A arte é o homem acrescentado à natureza, é o homem acrescentado à realidade, à verdade, mas com um significado, com uma concepção, com um caráter, que o artista ressalta, e aos quais dá expressão, resgata, distingue, liberta e ilumina.

(Van Gogh, 2008, p.38-9)

O propósito deste texto é, em um primeiro momento, a compreensão do elemento essencial e ativo que repousa na gênese histórica da arte, para que, em um segundo momento, possamos compreender seus desdobramentos na educação e traçar alguns norteadores para o ensino de literatura.

Para tanto, faremos uso do legado estético de George Lukács, filósofo húngaro marxista, e do psicólogo soviético L. S. Vigotski, também seguidor do materialismo histórico dialético.

1 Graduada em Ciências Sociais e Letras, doutoranda do Programa de Pós-Graduação em Educação Escolar da Universidade Estadual Paulista (Unesp), campus de Araraquara, com bolsa da Fundação de Amparo à Pesquisa do Estado de São Paulo (Fapesp). É membro do Grupo de Pesquisa "Estudos marxistas em educação". 
O trabalho para Marx é a categoria que define o ser social. Assim sendo, se compreendido em sua raiz histórica e material, o trabalho nos permite obter uma concepção de homem como ser que tem a necessidade de produzir os seus próprios meios de existência, seja ela material ou simbólica.

Destarte, a categoria de trabalho para o gênero humano é a demonstração máxima de sua condição ontológica inalienável. Por isso, tal categoria carece de uma análise bastante criteriosa e cuidada para que não incorramos em aplicações indevidas ou inadvertidas a qualquer tema em questão. $\mathrm{O}$ homem relaciona-se com a natureza por meio do trabalho em uma relação dialética, posto que a atividade do trabalho que imprime sobre a natureza, além de modificar a própria natureza, modifica a ele próprio: "atuando assim sobre o mundo exterior" e, simultaneamente, modificando a sua própria natureza.

Nesse sentido, tratar das formas abstratas do reflexo artístico pressupõe também a compreensão da gênese do trabalho e das formas de consciência dele advindas. O homem complexificou sua atividade de trabalho ao longo do processo de seu desenvolvimento até que ela viesse a ganhar características específicas, particularidades de uma atividade essencialmente estética. Sabemos, pois, que a relação sujeito-objeto iniciou-se com base na vida material dos homens, isto é, no trabalho, a atividade prática que separou o homem da natureza, que a transformou em objeto da atividade própria humana e, por efeito, fez do homem um sujeito. O trabalho é a forma primeira de relacionamento entre o homem e o mundo circundante. Ele é o alicerce, a fundação das diferentes formas de consciência, ou reflexo da vida material.

O trabalho implica necessariamente um reflexo correspondente do mundo concreto exterior. Essa premissa é a comprovação da prioridade do ser sobre a consciência. Em outras palavras, a ideia não se antepõe ao ser, a ideia de mundo não preexiste ao mundo factual, à realidade objetiva e concreta. Contudo, a consciência humana vai gradualmente atuando sobre o ser, submetendo este aos objetivos da ação previamente estabelecidos pela consciência. 
Daí surge uma das concepções categoriais mais representativas do marxismo: a teleologia humana. Os objetivos estabelecidos pela consciência dirigem a atividade humana e essa faz a mediação entre o plano objetivo e o subjetivo, entre a causalidade e a teleologia, entre a necessidade e liberdade. Lembremo-nos da famosa passagem de $O$ capital na qual Marx compara a atividade da abelha instintiva e irrefletida com o trabalho do arquiteto, guiado por uma antecipação mental do resultado pretendido e da atividade de construção da casa. Lukács (1966-1967), em sua obra enciclopédica Estética - obra que se esforçou para sistematizar e solidificar um pensamento estético marxista -, defendeu a radical historicidade tanto da criação artística quanto de sua recepção. O esforço de compreensão entre esses dois polos o acompanhou durante toda a sua jornada. Seu objetivo era compreender as origens, a gênese do reflexo artístico construído no bojo do processo de humanização.

Ainda que não houvesse em Marx um pensamento estético articulado, tão somente uma série de aforismos esparsos, ${ }^{2}$ os alicerces para a construção de um sistema estético estavam presentes em sua obra. Essa suposição é explicitada ainda nos primeiros ensaios sobre arte do pensador e, a partir daí, Lukács busca objetivar um pensamento estético marxista sistemático ainda inexistente que se aproximasse de sua essência verdadeira.

Em A peculiaridade do estético (ou somente Estética), Lukács (1966-1967) visa esclarecer a essência da arte no conjunto das demais objetivações do gênero humano, tendo como premissa a arte como fenômeno social de gênese histórica. Esse é o principal mote de oposição a Kant, expoente da corrente transcedentalista no campo

2 Conferir em português Marx \& Engels (1986). Há também uma outra obra assinada por Carlo Salinari que se preocupa em analisar o fenômeno artístico à luz dos princípios gerais da teoria marxista por meio de uma antologia de excertos marxianos e engelianos. Essa obra está editada em espanhol: Marx \& Engels (1975). Existe uma outra suma de passagens cuja tradução é de Eduardo Saló editada por uma editora portuguesa: Marx \& Engels (1976). Esse compêndio português distingue-se da coletânea brasileira por ser mais extenso e por dividir as passagens em diferentes tópicos. Com exceção da coletânea brasileira, facilmente disponíveis, os outros dois livros são mais raros. 
da estética. ${ }^{3}$ No prólogo da obra são apresentadas ideias que, além de sintetizar os rumos da investigação, também revelam o método estético-ontológico que deita suas raízes no materialismo histórico. Lukács declara irrevogável "fidelidade a realidade e fidelidade ao marxismo" (ibidem, p.16). A justeza com o referencial marxista é anunciada claramente no excerto a seguir:

Não há uma estética marxista [...] há de se conquistá-la, criá-la, inclusive mediante investigações autônomas [...] Mas esse paradoxo se dissipa enquanto se considera todo o problema à luz do método da dialética materialista [...] os métodos do materialismo histórico dialético indicam com claridade quais são os caminhos e como há de se reconhecê-los se se quer levar a realidade objetiva ao conceito, em sua verdade objetiva e aprofundar a essência de um determinado território de acordo com a verdade. Apenas realizando e mantendo, mediante a própria investigação, esse método, a orientação desses caminhos, se oferece a possibilidade de tropeçar com o buscado, de construir corretamente a estética marxista ou, ao menos, de aproximá-la de sua essência verdadeira. (ibidem) ${ }^{4}$

3 Conferir a Crítica do juízo de Emanuel Kant (1974). Obra elaborada em 1790 na qual Kant se ocupa do julgamento estético. Tendo por base o conceito de prazer desinteressado, a beleza estaria na atitude desinteressada do sujeito, em relação a qualquer experiência. O belo é aquilo que universalmente agrada que não pode ser justificado intelectualmente. $O$ princípio do juízo estético parte do sujeito, não do objeto. Contudo, há possibilidade de universalizar o juízo subjetivo uma vez que as condições de julgo do belo estariam em todo homem. A estética seria o puro juízo ou crítica do gosto. Assim, a universalidade, em contraposição à particularidade, dos juízos estéticos reside no fato que todos os homens têm a mesma faculdade de julgar. Além disso, a razão também seria um atributo idêntico para todos, independentemente do momento histórico, da realidade objetiva ou das condições materiais de existência. Trata-se, pois, de uma acepção transcedentalista da estética. De acordo com Celso Frederico, "A essência da arte é resultado de um longo desenvolvimento histórico, de uma necessidade surgida na vida cotidiana e não, como queria Kant, uma das faculdades apriorísticas do espírito humano (atividades cognitiva, prática e estética)" (Frederico, 2005, p.94).

4 São minhas as traduções do espanhol para o português dos excertos retirados da Estética de Lukács. 
Sobre a versatilidade filosófica que comporta a Estética, José Paulo Netto (1981, p.80) afirma:

De um lado, o filósofo ultrapassa as barreiras da literatura, objeto principal dos seus interesses: na Estética, ele procura determinar também a especificidade da música, da escultura, da arquitetura e do cinema; de outro, Lukács, para fundamentar a peculiaridade do estético, desenvolve formulações que dão conta de diferentes instâncias e planos da vida social (pode-se afirmar que a Estética contém teorias acerca da cotidianidade, da ciência e da religião).

Seu ponto de partida é a relação dialética entre a consciência humana e a realidade objetiva para analisar a formação do reflexo estético. Dessa maneira, Lukács traz à baila manifestações que poderíamos chamar de pré-artísticas. como o ritmo, a simetria-proporção e a ornamentística. De acordo com Bela Kiralyfalvi (1975, p.44), professor de artes, analista da Estética de Lukács,

o primeiro estágio na longa história de desenvolvimento da peculiaridade do reflexo artístico consiste no desenvolvimento de certas formas abstratas preliminares que não constituem a arte por si só, mas transformam-se em componentes essenciais da arte em estágios subsequentes. Essas formas abstratas são ritmo, simetria, proporção e ornamentística - arte decorativa. (Tradução nossa)

Comecemos nossa análise pelo ritmo, a forma artística abstrata mais essencial, posto que é um elemento fundamental na e para a existência humana.

Ele se encontra tanto na natureza como no próprio corpo humano e na vida cotidiana dos homens. Existe uma gama de processos rítmicos que integram a natureza: o dia e a noite, as estações, os movimentos terrestres, o movimento de asas que possibilita o voo dos pássaros. Além desses, existem os ritmos da própria fisiologia humana, como a respiração, os batimentos cardíacos. Esse ritmo "natural” também influenciou a esfera do trabalho humano. Lukács diz 
que a passagem da esfera natural para a esfera social do ritmo surge graças ao trabalho e suas implicações teleológicas: "no trabalho, o homem toma um pedaço da natureza, o objeto do trabalho e o arranca de sua conexão natural, o submete a um tratamento pelo qual as leis naturais se aproveitam teleologicamente numa humana posição de fins” (Lukács, 1966-1967, v.1, p.268, tradução nossa).

Por meio do trabalho, o ritmo surge como predicado ontológico do ser social. Na verdade, o trabalho e a arte, de maneira geral, se cumprem como atividades teleológicas.

Toando a cadência e dando compasso aos movimentos do trabalho, o ritmo remonta suas raízes originais na história do processo de hominização e humanização e segue diversificando-se, conforme o avanço das relações entre o homem e a natureza. $\mathrm{O}$ salto da natureza à vida social propiciado pelo trabalho possui dimensões histórico-universais, pois, por meio dele, o homem se diferencia dos demais seres vivos.

Lukács rejeita a teoria idealista de que ritmo é uma característica humana dada a partir de forças superiores, bem como o pressuposto aristotélico de A Poética de que a percepção de ritmo é natural para o homem. O grau rítmico humano natural é o mesmo de que dispõe os animais, e até esse ponto, o ritmo não é univocamente humano. $\mathrm{O}$ ritmo animal é espontâneo e inato, enquanto ritmo excepcionalmente humano é desenvolvido e aperfeiçoado pelo homem por meio da prática consciente. As diferentes formas de ritmo entram em nossa consciência, como os sons que se originam quando ferramentas entram em contato com os materiais. O ritmo do trabalho torna mais eficaz e mais fácil tanto física como psicologicamente, e por esses motivos é cultivado como uma sensação de prazer. Nesse ponto, porém, ritmo ainda é apenas um elemento da vida cotidiana, e só mais tarde, por meio de danças rituais, cantos e música, que também são direcionados para necessidades práticas, se tornou uma reflexão sobre esses fatores da vida (Kiralyfalvi, 1975).

Ao contrário do que pregavam as teorias estéticas e filosóficas idealistas, o ritmo não tem como fundamento nenhuma origem mística. Para Lukács, o fundamento do ritmo estético não é instintivo 
ou involuntário, ou seja, não é atividade inata. O ritmo é fruto da prática dos homens e é socialmente condicionado. O surgimento do ritmo para a estética é produto da manifestação da autoconsciência, é uma criação humana, uma criação verdadeira e objetiva, e não advinda do universo delirante, fantasmal e imagístico da religião. Eis o caráter imanentista da arte, tão amplamente difundido pelo filósofo marxista húngaro.

O ritmo migrou da natureza para o trabalho (e para o cotidiano) e do trabalho para os domínios da arte, conferindo-lhe peculiaridade. A autonomia artística do ritmo se deu quando ele passou a existir fora de sua manifestação imediata no processo de trabalho, quando deixa de ser um momento da vida cotidiana para ser o reflexo desse momento.

É somente no reflexo artístico que o ritmo gera seu fim evocador. Ele passa para o mundo simbólico dos homens, intensificando seu aspecto consciente e, dessa forma, imprime significado e sentido próprios do universo artístico feito pelo homem e para o homem. "Se no trabalho o ritmo é um reflexo, na arte, a autonomização destinada a evocar sentimentos humanos, a interioridade do homem, produz um afastamento do mundo imediato que o trabalho não pode se permitir" (Frederico, 2005, p.105).

Outro pensador marxista que ofereceu grandes contribuições pra o campo da psicologia estética foi o psicólogo soviético S. LVigotski. A categoria imprescindível para se entender o legado vigotskiano sobre arte é o de catarse psicofísica. Vigotski refaz o percurso dessa "necessidade" humana de alta complexidade a partir dos estudos de Viessielovski. Segundo esse autor, a canção mais remota e o jogo, aliás, nascem no momento em que o homem passa a sentir o imperativo catártico. $\mathrm{O}$ canto em coro serviria, portanto, para aliviar por meio do ritmo, a tensão muscular durante o trabalho exaustivo executado. A partir desse momento surge a tendência rítmica do poema. Quando a arte se separa definitivamente do trabalho, os sentimentos de angústia e tensão advindos dele passam a ser estimulados dentro da própria arte.

Na poesia, considerada por muitos a arte rítmica da palavra, o ritmo ganhou novos contornos e direções. Em um poema seria im- 
possível analisarmos seus elementos constitutivos isoladamente, pois todos tecem uma unidade poemática. Mas se quiséssemos buscar um elemento essencial, fundamental para a caracterização de um poema, de certo culminaríamos no ritmo, a alma do poema.

Conforme Antonio Candido (2006, p.69), os fragmentos sonoros estão intimamente ligados e ao mesmo tempo subordinados a um todo maior e dominante: o ritmo. O ritmo seria então "uma alternância de sonoridades mais fracas e mais fortes, formando uma unidade configurada".

Para que compreendamos o fenômeno do ritmo devemos admiti-lo como elemento indissociável ao tempo. Candido complementa:

Metaforicamente, podemos falar do ritmo de um quadro; mas no sentido próprio, só falamos do ritmo de um movimento. $\mathrm{O}$ encadeamento dos sons, a sucessão de gestos possuem ritmos. Por isso nos só podemos usar este conceito com precisão nas artes que lhe correspondem; música, poesia, dança. Isto, a despeito dos teóricos da Antiguidade já utilizarem a palavra ritmo para exprimir a simetria das artes plásticas, e a despeito do hábito ter-se enraizado definitivamente na linguagem estética. (ibidem, p.67-8)

Como já explicitado, o ritmo é a alma, o agente do movimento sonoro, o norte direcionador de todo significado do ser poema. Muitos chegaram à conclusão de que a gênese do ritmo na poesia seria tão somente uma tradução nas artes das realidades naturais, orgânicas da vida: o batimento cardíaco, a cadência de andar, a respiração . Tomando-se por base apenas essa premissa, o ritmo não teria outro argumento de origem além de sua manifestação puramente biológica. Como vimos, para Lukács a origem do ritmo estético admite mais do que essa explicação. Sua manifestação é, antes de tudo, uma manifestação da atividade social humana, o trabalho, já que o movimento produtivo é mais eficiente se regulado por uma marcha ritmada. Existe, aliás, uma economia notável de esforço e a maximização da produtividade quando o trabalho humano coletivo é marcado pelo ritmo cadenciado. Basta observarmos a cadência das 
foices no campo, dos martelos nas linhas de produção, de um grupo de homens erguendo uma pedra com a força mecânica de seus próprios braços. Certamente, essas atividades não se efetivariam sem coordenação rítmica dos movimentos; o cansaço físico é minimizado e a resistência majorada.

Estamos, portanto, diante de duas concepções distintas a respeito da origem do ritmo. A primeira delas afirma que ele apenas precede a consciência humana, e a segunda, à qual se filia Lukács, afirma que ele é produto da atividade social humana, do trabalho, em sua essência.

Se no primeiro caso a concepção de ritmo é transcendente, ou seja, possui uma fonte apriorística e natural, no segundo, a natureza rítmica no campo da estética possui suas bases na vida social, na realidade objetiva.

Não se trata de negarmos as modulações rítmicas existentes na natureza. É possível observarmos casos bastante emblemáticos de pássaros que cantam ritmada e melodiosamente, o sabiá, o canário-da-terra, por exemplo. Contudo, o ser humano, aproveitandose desse movimento da natureza, transforma-o dialeticamente em matéria de arte, transmutando, assim, sua própria natureza, seu sentido e especificidade. Trata-se, pois, de admitirmos o ritmo como uma realidade objetivamente compreensível da vida social humana, existente no trabalho e nas artes:

Quando o homem imprime ritmo à sua palavra, para obter efeito estético, está criando um elemento que liga esta palavra ao mundo natural e social; está criando para esta palavra uma eficácia equivalente à eficácia que o ritmo pode trazer ao gesto humano produtivo. Ritmo é, portanto, elemento essencial à expressão estética nas artes da palavra, sobretudo quando se trata de versos... (Candido, 2006, p.71-2)

O que discutimos até agora foi o fato de que os elementos naturais criam novas conexões graças ao trabalho humano que põe finalidades no mundo exterior. Nesse momento, os elementos apropriados da 
natureza pelo ser humano (ritmo, simetria-proporção e ornamento) são transformados em elementos do mundo das ações humanas guiadas por finalidades conscientes. A passagem para os domínios da arte, entretanto, só se configura quando o belo se separa de sua utilidade imediata e passa a evocar sentimentos humanos. Como no trabalho, na ciência e no cotidiano, o reflexo artístico pressupõe uma apropriação constante dos elementos que legitimamente compõem o mundo exterior objetivado.

Marx (1989) havia concentrado sua atenção no trabalho como a forma básica de atividade que integrava o indivíduo com o gênero humano. Nos manuscritos de 1844, o desenvolvimento de formas abstratas da consciência humana é descrito como "a riqueza da subjetiva sensibilidade humana...", o ouvido para a música, o olho para a beleza da forma, em suma. são capazes de sensibilidades para fruição humana, sensibilidades que se manifestam como potencialidades humanas.

Lukács retoma essa junção por meio da arte, essa forma de atividade humana tardia que prolonga, com seus meios próprios, a objetivação do ser social no mundo exterior, a declaração da subjetividade humana no objeto estético. Lukács conclui que a obra de arte é a "memória da humanidade", registro dos diversos momentos de sua trajetória. "Como materialista, Lukács reafirma a anterioridade da matéria em relação à consciência, bem como o caráter de reflexo desta última. Mas, na Estética, o esforço para determinar a especificidade da arte levou-o a redefinir o papel do reflexo artístico" (Frederico, 2005, p.104-5).

Kiralyfalvi (1975, p.45) resume a empreitada estética lukacsiana reiterando sua irrevogável pretensão comunista:

A perspectiva ontológica por ele realizada revela a convicção de que não existe um grande plano preconcebido para o desenvolvimento do homem, da sociedade, nem um fim para o desenvolvimento, há apenas uma direção que é modificável e alterada pelos homens, dependendo do seu grau de consciência, incluindo a autoconsciência. A direção "alterável" é o comunismo, com a ciência e a arte fornecen- 
do os meios necessários para a expansão da consciência do homem e da autoconsciência. $\mathrm{O}$ alcance dessa meta, portanto, depende inteiramente dos homens. Já que o humanismo de Lukács investe muita fé nos homens, a fé que ele verifica a partir de sua leitura da história, talvez sua visão marxista sobre o futuro da arte e da sociedade seja melhor descrita como otimista e não utópico. (Tradução nossa)

Vigotski também analisou os efeitos da arte sobre o indivíduo, contudo seu campo de investigação é o da psicologia. O grande sentimento estético encerra necessariamente uma contradição emocional, ou seja, um encadeamento de sentimentos antitéticos cujo resultado será, nas palavras de Vigotski (1999, p.270), um "curto-circuito interior". Em suma, a natureza contraditória "subjaz à estrutura de toda obra de arte" (ibidem).

A isso podemos chamar o verdadeiro efeito da obra de arte, e nos aproximamos especificamente de um conceito fundamental para qualquer análise estética marxista, a categoria de catarse.

O temário poético de Aristóteles inaugura o conceito de sentimento catártico. Em sua primeira acepção, o termo era relacionado a uma coesão social bastante cara à sociedade ateniense, bem como a uma forma particular de composição: a tragédia. Aristóteles (1973) foi o primeiro pensador a escrever um tratado sistematizado sobre a arte da palavra intitulado "Poética". Segundo o filósofo grego, a poética é mimesis, abrangendo a poesia épica, a tragédia e a comédia. A mimese visa à recriação e a recriação visa àquilo que pode ser. O outro conceito cunhado por Aristóteles é exatamente o de catarse - do grego kátharsis - que etimologicamente significa purgação, purificação, descarga que alivia e, ao mesmo tempo, permite o registro da experiência. O termo significa, além disso, o efeito moral e purificador, de extrema intensidade e violência para com o indivíduo; traz à tona os sentimentos de terror e piedade dos espectadores, proporcionando-lhes o alívio, ou purgação de seus próprios sentimentos. As considerações acerca da mimesis (traduzido como imitação) e katharsis (traduzido por purgação, purificação) serão as peças fundamentais da Poética: 
É, pois, a tragédia imitação de um caráter elevado, completa e de certa extensão, em linguagem ornamentada e com as várias espécies de ornamento distribuídas pelas diversas partes do drama, imitação que se efetua não por narrativa, mas mediante atores, e que suscitando o terror e a piedade, tem por efeito a purificação destas emoções. (Aristóteles, 1973, p.28)

Segundo Aristóteles, se "a vista das imagens" proporcionar prazer e deleite a quem as contempla, não apenas a poesia, mas, sobretudo, o fazer poético serão consumados em plenitude.

De acordo com o dicionário de Filosofia Nicola Abbagnano (2007, p.137), o termo catarse é de origem médica, significando literalmente "purgação”. Platão determina outro significado ao conceito. Catarse seria "a discriminação que conserva o melhor e rejeita o pior”. Nota-se em Platão uma significação mais moral e metafísica, uma vez que designa duas definições. A primeira delas seria a "libertação em relação aos prazeres" e a segunda, "a libertação da alma em relação ao corpo, no sentido de que a alma se separa ou se retira das atividades físicas e realiza, já em vida, a separação total, que é a morte". Aristóteles também fez uso desse termo no sentido médico que carrega, em especial, nas obras sobre história natural, admitindo-se sua tradução como purgação ou purificação. Contudo, ele foi o primeiro a ampliar o conceito a uma dimensão estética "qual seja, uma espécie de libertação ou serenidade que a poesia, em particular, o drama e a música provocam no homem" (ibidem, p.138).

Vigotski (1999, p.269) afirma que dessa palavra enigmática emergiram inúmeras interpretações além do conteúdo que lhe conferiu Aristóteles:

Entendemos com Lessing, a catarse como efeito moral da tragédia, a "conversão" das paixões em inclinações virtuosas ou, com E. Muller, como passagem do desprazer para o prazer, e assim temos a interpretação de Bernays, segundo quem essa palavra significa cura e purificação no sentido médico, ou a opinião de Zeller, para quem a catarse representa tranqüilização da emoção. 
Essa categoria, porém, que ao longo da história admitiu inúmeras modulações, possui um significado bastante particular na pedagogia histórico-crítica, cuja viga mestra são as obras teóricas de Dermeval Saviani.

Para Saviani (2007, p.78), a catarse é conceituada a partir da visão gramsciniana "elaboração superior da estrutura em superestrutura na consciência dos homens". Essa elaboração atua sobre a forma histórica e social de se pensar, acionando as estruturas psíquicas do indivíduo resultantes do processo educativo e não de um princípio natural ou inato. Internaliza-se, pois, o conhecimento, os instrumentos culturais, ativos de transformação social.

Para que entendamos o momento da catarse, no cerne da prática pedagógica escolar, é necessário, antes de tudo, compreendermos o processo de homogeneização. Conforme Duarte (2007, p.61), o cotidiano estaria para o polo heterogêneo, enquanto as esferas superiores de objetivação do gênero humano, como a ciência, a filosofia e a arte, estariam para o polo homogêneo. A educação escolar tem como objetivo formar o indivíduo para a vida social em sua totalidade. Para isso, é mister que se utilize das objetivações homogêneas no exercício de compreensão da situação social, transcendendo, assim, as formulações epiteliais do senso comum.

Duarte exemplifica as relações entre a consciência individual e as objetivações mais elevadas do gênero humano mostrando que a ciência da história é necessária à compreensão da condição de pertencimento a uma classe social:

A ciência historiográfica torna-se, assim, o meio homogêneo através do qual esse indivíduo busca se relacionar conscientemente com sua condição de classe. É claro que trata-se de um exemplo esquemático, pois juntamente com essa objetivação genérica para-si, normalmente estão presentes também relações com outras objetivações. No exemplo citado, podem estar presentes também relações com valores morais, com objetivações filosóficas e até mesmo com objetivações artísticas (quando, por exemplo, uma determinada obra de arte contribui para que o indivíduo desfetichize a realidade social da qual ele é parte). (ibidem, p.65) 
É preciso que o indivíduo olhe para além do meio social imediato no qual se desenvolvem suas atividades cotidianas, ou, nas palavras de Duarte, é necessário "tornar-se capaz de se distanciar desse ponto de visão e olhar o mundo tomando um ponto de referência externo a si próprio" (ibidem, p.68).

No caso específico da obra de arte, na abordagem de Lukács (1989), o indivíduo pode superar uma visão particular e olhar o mundo por meio das lentes universais da arte. Esse movimento de superação da particularidade individual também recai sobre o artista no momento de formulação e construção do objeto estético: "toda boa arte e toda boa literatura também é humanista na medida em que não apenas estuda apaixonadamente o homem, a verdadeira essência de sua constituição humana, mas também que, ao mesmo tempo, defende apaixonadamente a integridade humana do homem" (ibidem, p.213).

Deriva-se dessa premissa o conceito de catarse que vai além de sua acepção estética, alargando-se às mais variadas áreas de ação do homem, inclusive a educação. O momento catártico se dá quando "o processo e homogeneização produz um salto qualitativo na consciência do indivíduo [...]. Assim a catarse aparece na relação entre indivíduo e a obra de arte, entre indivíduo e ciência, entre indivíduo e valores morais" (Duarte, 2007, p.70).

No caso particular da arte, a função catártica diante do objeto estético, nas concepções vigotskiana e lukacsiana, é contribuir para transformar o arranjo da consciência dos homens, conferindo-lhes novas formas de apreensão do real e substância crítica capaz de confrontar a sociedade capitalista em sua totalidade.

A escola, entretanto, instituição cuja especificidade residiria, conforme Saviani (1995), na socialização do saber, reserva na atualidade um espaço mínimo para a compreensão da riqueza artística da humanidade, e muitas vezes o faz de maneira distorcida. ${ }^{5} \mathrm{~A}$ arte

5 Note-se que a secundarização do conhecimento artístico na escola atual não se faz em favor do conhecimento científico, mas sim em favor de um currículo constituído de uma multiplicidade de atividades voltadas para os mais diversos e dispersos temas, em geral ligados às necessidades pragmáticas do cotidiano. 
literária, em especial, sofre efeitos nefastos oriundos do descaso perante o universo estético da humanidade.

$\mathrm{Na}$ atualidade, grande parte do ensino de literatura abrevia-se em um compilado de informações rapidamente consumíveis, tendo como finalidade única os exames para ingresso no Ensino Superior. A história literária tal qual se apresenta no ambiente escolar acanha e abrevia o conteúdo a uma espécie de modelo deformado e "desistoricizado" da obra literária. Aprende-se de maneira atrofiada um compêndio literário, características meramente descritivas e superficiais de uma determinada postura estética, e justapõe-se a isso o manuseio de fichas com resumos das obras literárias. Quase nunca o aluno é levado a realizar uma real atividade de leitura da obra literária, ou seja, exclui-se do ensino de literatura aquilo que justifica a própria existência da literatura: a vivência estética do texto literário por seus leitores.

A estética marxista propicia uma compreensão profunda, de preocupação com a dignidade humana, de busca da essência e dos fenômenos presentes numa obra de arte e que, ao refletir seu tempo, se torna patrimônio humano-genérico. Sabemos, todavia, que muito pouco foi realizado para construção efetiva de uma educação estética de qualidade.

Para Marx (1989, p.178), "o homem rico é simultaneamente o homem necessitado de uma totalidade da manifestação humana da vida". Esse é o ponto de partida para entendermos o processo de humanização por meio das artes:

Não só no pensar, por conseguinte, mas com todos os sentidos o homem é afirmado no mundo objetivo. Por outro lado, tomado subjetivamente: assim como primeiro a música desperta o sentido musical do homem, assim como para o ouvido não musical a mais bela música não tem nenhum sentido, [não] é objeto, porque o meu objeto só pode ser a confirmação de uma das minhas potências essenciais, portanto, só pode ser para mim da maneira como a minha potência essencial é para si como capacidade subjetiva porque o sentido de objeto para mim [...] vai exatamente até o ponto em que 
vai o meu sentido, é por isso que os sentidos do homem social são sentidos outros do que os não-social. (ibidem, p.175)

A formação dos sentidos e das sensibilidades humanas é um processo dialético desenvolvido ao longo da história social e subordinado às condições objetivas de cada momento histórico.

Dessa maneira, entendemos que a arte, e em seu interior a literatura, é uma das manifestações da vida humana cuja necessidade precisa ser criada nas novas gerações pela escola pública.

Segundo Lukács, a arte tem a tarefa de nos conduzir a uma realidade diferente daquela imediatamente observável no cotidiano. Nessa imediatidade cotidiana o extrato aparente turva e dissimula a verdadeira essência. Ao contrário da experiência cotidiana, a experiência artística nos direciona a uma realidade objetiva, superior e precisa.

A arte, porém, não será elemento constitutivo na realização da essência humana se ela não existir como possibilidade produzida pelo processo histórico-social objetivo, ou seja, à medida que o ser humano não se apropria dessa possibilidade, ou não quer dela apropriar-se, estamos, efetivamente, diante de um processo de alienação.

Analisando todos esses elementos constitutivos do universo estético lukacsiano, acreditamos que a estética marxista propicia uma compreensão profunda, de preocupação com a dignidade humana, de busca da essência e dos fenômenos presentes numa obra de arte, e que, ao refletir seu tempo, torna-se patrimônio humano-genérico. Sabemos, todavia, que muito pouco foi realizado para a construção efetiva de uma educação estética de qualidade.

Nesse sentido, o compromisso que a pedagogia histórico-crítica (Saviani, 1995) tem com a educação e com os conteúdos escolares coaduna-se com a altura da riqueza cultural humana objetivamente existente e, igualmente, com as premissas estéticas marxistas. Como já mencionado, é preciso que o aluno entre em contato com o patrimônio literário de mais alto grau de elaboração humana. Essa é uma responsabilidade à qual uma educação emancipadora não se pode furtar. 
Sendo assim, a literatura universal deve ser socializada como conteúdo indispensável para melhor compreensão da "complexidade do mundo e dos seres" como diz Antonio Candido (1995, p.3).

O que temos observado no ensino de literatura contemporaneamente reflete o esvaziamento da especificidade do conteúdo literário. As aulas de literatura dissolveram-se em outras disciplinas, perderam seu caráter eminentemente estético e, além disso, trabalham com uma concepção pós-moderna do conceito de literatura, como notamos nas análises dos PCN para o Ensino Médio (Brasil, 2000 e 2006).

Acreditamos que a verdadeira formação dos sentidos e das sensibilidades humanas, na concepção de Marx, é um processo dialético desenvolvido ao longo da história social e subordinado às condições objetivas de cada momento histórico. A efetiva formação dos sentidos e sensibilidades por meio da vivência estético-literária é, sem dúvida, uma via vultosa para emancipação e para liberdade humana. De tal modo, entendemos que a arte, e em seu interior a literatura, é uma das manifestações da vida humana cuja necessidade precisa ser criada nas novas gerações pela escola pública.

\section{Referências bibliográficas}

ABBAGNANO, N. Dicionário de filosofia; tradução da $1^{a}$ edição brasileira coordenada e revista por Alfredo Bosi; revisão da tradução e tradução de novos textos: Ivone Castilho Benedetti. 5.ed. São Paulo: Martins Fontes, 2007.

ARISTÓTELES. Poética. São Paulo: Abril Cultural, 1973. (Col. Os pensadores).

BRASIL. Secretaria da Educação Básica. Parâmetros Curriculares Nacionais-Ensino Médio: Linguagens, Códigos e suas Tecnologias. Parte II, 2000. Disponível em: <http://paisonline.homestead.com/PCNLing. pdf>. Acesso em: 4 maio 2007.

Orientações curriculares para o Ensino Médio: Linguagens, códigos e suas tecnologias. Brasília: Ministério da Educação, Secretaria de Educação Básica. v.1, 2006. Disponível em: <http://portal.mec.gov. $\mathrm{br} / \mathrm{seb} /$ arquivos/pdf/book_volume_01_internet.pdf $>$. Acesso em: 4 maio 2007. 
CANDIDO, A. O direito à literatura. In: Vários escritos. São Paulo:

Duas Cidades, 1995.

. O estudo analítico do poema. 5.ed. São Paulo: Associação Editorial Humanitas, 2006.

DUARTE, N. Educação escolar, teoria do cotidiano e a escola de Vigotski. Campinas: Autores Associados, 2007.

FREDERICO, C. Marx, Lukács: a arte na perspectiva ontológica. Natal: EDUFRN, 2005.

KANT, E. Primeira introdução à crítica do juízo. Trad. Rubens Rodrigues Torres Filho. São Paulo: Abril Cultural, 1974. (Col. Os pensadores Kant II).

KIRALYFALVI, B. The aesthetics of Gyorgy Lukacs. Princeton: Princeton University Press. 1975.

LUKÁCS, G. Estética. Barcelona: Grijalbo, 1966-1967. 4v.

. Sociología de la literatura. Traduzido do original em alemão por Michael Fabern Kaiser. 4.ed. Barcelona: Península, 1989.

MARX, K. Manuscritos econômico-filosóficos de 1844. Traduzido do original em alemão por Viktor von Ehrenreich. In: FERNANDES, F. (Org.) Marx e Engels: História. 3.ed. São Paulo: Ática, 1989. p.146-81. (Col. Grandes cientistas sociais).

MARX, K; ENGELS, F. Cuestiones de arte y literatura. 2.ed. Barcelona: Ediciones Península, 1975. Literatura e arte. Trad. Eduardo Saló. Lisboa: A Comuna, 1976. Sobre literatura e arte. 3.ed. São Paulo: Global, 1986.

PAULO NETTO, J. Capitalismo e reificação. São Paulo: Livraria Editora Ciências Humanas, 1981.

SAVIANI, D. Pedagogia histórico-crítica: primeiras aproximações. 5.ed. Campinas: Autores Associados, 1995. . Escola e democracia. 39.ed. Campinas: Autores Associados, 2007. VAN GOGH, V. Cartas a Théo. 2.ed. Porto Alegre: L\&PM, 2008. VIGOTSKI. L. S. Psicologia da Arte. São Paulo: Martins Fontes, 1999. 


\title{
8 \\ O TRABALHO DO PROFESSOR \\ E A ALFABETIZAÇÃO: UMA ANÁLISE DOS IDEÁRIOS EDUCACIONAIS
}

\author{
Fatima Aparecida de Souza Francioli ${ }^{1}$
}

Neste texto apresento uma reflexão resultante da profissão que exerço, professora do curso de Pedagogia em uma faculdade pública do Estado do Paraná, e dos estudos teóricos que estou realizando para a tese de doutorado. A trajetória docente começou muito antes de ter chegado ao nível superior. Na verdade, teve início na década de 1980 como professora alfabetizadora da rede pública municipal em uma cidade do interior do Paraná.

Nessa época iniciava-se a implantação da teoria da psicogênese da língua escrita ${ }^{2}$ nos curso de formação inicial e continuada dos

1 Pedagoga, mestre em Educação pela Universidade Estadual de Ponta Grossa (UEPG) e doutoranda do Programa de Pós-Graduação em Educação Escolar na Universidade Estadual Paulista (Unesp), campus de Araraquara. É professora do curso de Pedagogia da Faculdade Estadual de Educação, Ciências e Letras de Paranavaí (Fafipa) (PR) e membro do Grupo de Pesquisa "Estudos marxistas em educação".

2 Essa teoria cunhada pelas autoras Emilia Ferreiro e Ana Teberoski, que pertenceram à escola do epistemólogo e psicólogo Jean Piaget, "deslocou a questão central da alfabetização do ensino para a aprendizagem: partiu não de como se deve ensinar e sim de como de fato se aprende [...]. O que Emilia Ferreiro e Ana Teberosky demonstraram é que a questão crucial da alfabetização inicial é de natureza conceitual. Isto é, a mão que escreve e o olho que lê estão sob o comando de um cérebro que pensa sobre a escrita que existe em seu meio social e com a qual toma contato através da sua própria participação em atos que envolvem o 
professores oferecidos pelas secretarias estaduais e municipais de Educação. Lembro-me, com clareza, dos cursos de capacitação que nos eram oferecidos. Consistiam em cursos com pouquíssima fundamentação teórica e muitas atividades que deveriam ser desenvolvidas nas salas de alfabetização. A ordem era: "Abandonem as cartilhas, usem-nas somente para recortes, porque agora iniciaremos a alfabetização por textos”. Era notável a angústia das professoras que lecionavam há mais tempo, que usavam as cartilhas e as sílabas para alfabetizar. Como seria trabalhar com textos? Voltávamos para a escola com muitas dúvidas, angústias, sem saber muito que fazer, porque, afinal, todos da escola, desde a diretora, as supervisoras e o corpo de professores não sabiam por onde começar.

Provavelmente muitas foram as saídas encontradas pelos professores, desde a continuação da alfabetização com a cartilha "escondida" entre os materiais e o uso das famílias silábicas recortadas como alfabeto móvel até as tentativas de ensinar com os diferentes textos. Os anos se passaram e a nova proposta de alfabetização foi se consolidando nas escolas com a chegada de livros didáticos, que no lugar das famílias silábicas traziam diferentes textos para serem trabalhados com os alunos. Em outubro de 1996, a revista Nova Escola n.97 trouxe estampada em sua capa uma foto em que reunia Branca Alves de Lima e Maria Fernandes Cócco, duas autoras de livros didáticos para alfabetização. Logo abaixo da foto, o enunciado "A car-ti-lha se adapta aos novos tempos. O método silábico mantém a liderança, mas o construtivismo abre espaço no material de alfabe-

ler ou o escrever, em práticas sociais mediadas pela escrita [...]. A mudança na compreensão do processo pelo qual se aprende a ler e escrever afetou também todo o ensino da língua. Permitiu que o conhecimento produzido na área da lingüística encontrasse receptividade na escola e que, nestes últimos 20 anos, se produzisse experimentação pedagógica suficiente para construir, a partir delas, uma didática. Esta didática da língua - que trouxe os textos do mundo para dentro da escola e se preocupa em aproximar as práticas de ensino da língua das práticas de leitura e escrita reais - é a que vem sendo difundida pelo Ministério da Educação nos Parâmetros e Referências Curriculares Nacionais para a educação básica” (Weisz, 1999). 
tização mais adotado neste século”. Oito páginas da revista foram dedicadas ao assunto, fazendo um paralelo entre a alfabetização com a cartilha Caminho suave de Branca Alves de Lima que, lançada em 1950, já havia vendido até aquela data 40 milhões de exemplares, e a alfabetização com o livro ALP - Alfabetização, Linguagem e Pensamento, de Maria Fernandes Cócco, que, lançado em 1995, com uma proposta supostamente $100 \%$ construtivista, vendera, em um ano, 100 mil exemplares. É preciso recordar que também foi em 1996 que os Parâmetros Curriculares Nacionais (PCN) para o primeiro e segundo ciclos do Ensino Fundamental chegaram às escolas públicas brasileiras, fundamentados na teoria construtivista.

Dentro desse quadro, fica claramente definido que a teoria construtivista havia sido adotada pelos órgãos oficiais de educação nacional e, como tal, também deveria ser adotada por toda a rede pública de educação. A proposta de que não haveria mais exercícios com sílabas e que a alfabetização deveria iniciar com textos fazia que muitos alunos concluíssem o primeiro ano letivo escrevendo pequenos textos. De acordo com a proposta apresentada por Ferreiro \& Teberoski (1999), a evolução da escrita percorre cinco níveis: no primeiro nível a criança reproduz os traços de escrita com o qual se identifica, ou seja, de imprensa ou cursiva; no segundo nível a criança acredita que para poder ler coisas diferentes deve escrever de maneira diferente, definindo grafismos mais próximos das letras; no terceiro nível denominado hipótese silábica, em que cada letra vale uma sílaba, a criança trabalha com a tentativa de dar valor sonoro às letras que utiliza para escrever; o quarto nível é o momento que a criança passa da hipótese silábica para a alfabética, ou seja, a criança entra em conflito entre a quantidade de letras que utiliza para escrever e a quantidade de letras que o meio social lhe propõe; o quinto e último nível é denominado escrita alfabética.

A escrita alfabética constitui o final desta evolução. Ao chegar a este nível, a criança já franqueou a "barreira do código"; compreendeu que cada um dos caracteres da escrita corresponde a valores sonoros menores que a sílaba e realiza sistematicamente uma análi- 
se sonora dos fonemas das palavras que vai escrever: Isto não quer dizer que todas as dificuldades tenham sido superadas: a partir desse momento, a criança se defrontará com as dificuldades próprias da ortografia, mas não terá problemas de escrita, no sentido restrito.Parece-nos importante fazer esta distinção, já que amiúde se confundem as dificuldades ortográficas com as dificuldades de compreensão do sistema de escrita... (Ferreiro \& Teberoski, 1999, p.219, grifos do autor)

Ao implementar essa proposta no processo de alfabetização, não caberia ao professor alfabetizador a preocupação da correção ortográfica e da pontuação, porque o que importava é que eles escrevessem para expressar as ideias; a correção caberia à professora da série seguinte. Assim, por longos anos, todos os cursos de capacitação oferecidos pelas secretarias de Educação eram para ensinar os professores a trabalhar com textos.

Depois de duas décadas trabalhando como professora e coordenadora pedagógica das séries iniciais do Ensino Fundamental cheguei ao mestrado em Educação com a proposta inicial de pesquisar a formação continuada dos professores que se pautava pelos Parâmetros Curriculares Nacionais cujo material eu conhecia tão bem, pois ministrava cursos utilizando o material dos PCN e depois o material do Programa de Formação de Professores Alfabetizadores (Profa). ${ }^{3}$ No entanto, em meio à minha caminhada de pesquisa, deparei com a orientação da professora Esméria de Lourdes Saveli,

3 "O Profa - Programa de Formação de Professores Alfabetizadores é um curso de aprofundamento, destinado a professores e formadores que se orienta pelo objetivo de desenvolver as competências profissionais necessárias a todo professor que ensina a ler e escrever. Por intermédio deste projeto serão oferecidos meios para criar um contexto favorável para a construção de competências e conhecimentos necessários a todo professor que alfabetiza. Que condições são essas? Um grupo de formação permanente, um modelo de trabalho pautado no respeito aos saberes do grupo e em metodologias de resolução de problemas, materiais escritos e videográficos especialmente preparados para o curso e uma programação de conteúdos que privilegia aqueles que são nucleares na formação dos alfabetizadores" (Brasil, 2001, p.5). 
na Universidade Estadual de Ponta Grossa (UEPG/PR), que me convenceu a pesquisar sobre a alienação do trabalho docente. É possível entender meu desespero quando deparei com teóricos que ainda não havia estudado, começando por Marx, Saviani, Mészáros, Kosik, Duarte e tantos outros que escreviam a partir de uma análise crítica da sociedade capitalista. Confesso que foi uma tarefa árdua, mas tornou-se um divisor de águas na minha vida tanto profissional como pessoal. A análise começou pela compressão do próprio nível de alienação em que me encontrava como professora.

Diante do exposto, iniciarei minha reflexão apresentando uma síntese da dissertação de mestrado que concluí em 2005 na UEPG/ PR intitulada Profissão docente: uma análise dos fatores intervenientes na prática educativa (Francioli, 2005). Para fazer essa análise teórico-metodológica, fundamentei-me na concepção materialista histórica e dialética para dar sustentação à pesquisa, que objetivava compreender quais eram os fatores que contribuíam para manutenção da alienação no trabalho do professor. Ao me debruçar sobre as leituras teóricas, tinha que apreender o conceito de alienação definido pela teoria marxista, isto é, compreender que o princípio da alienação está centrado na divisão social do trabalho e no surgimento da propriedade privada. Esse entendimento, somado a outras questões que foram se esclarecendo, levou-me a concluir que a escola, como todas as demais instituições existentes em nossa sociedade, está inserida na lógica do capital e, portanto, "nesse processo, a escola, sob os moldes do capitalismo, enquadra os homens num processo de massificação, ou seja, educa para que todos reproduzam as mesmas idéias, pensamentos e vontades dos que dominam, suprimindo a individualidade do trabalhador" (ibidem, p.12).

O caráter contraditório da sociedade capitalista se reflete no sistema escolar vigente, desdobrando-se em diversos tipos de contradição, nas quais se manifesta a luta entre o caráter humanizante da transmissão às novas gerações das obras mais ricas do conhecimento humano e o caráter alienante da reprodução da ideologia burguesa. Mediante essa compreensão teórica, a pesquisa apontou duas questões relevantes que eram observáveis no espaço da escola: 
A primeira emergiu dos depoimentos dos professores que traziam um acentuado sentimento de impotência, de desconforto e decepção gerados pelos resultados das avaliações feitas da aprendizagem dos alunos. A segunda evidenciou um descompasso entre o que os professores apregoavam (diziam fazer) e o que realmente faziam na sua prática docente. Isto é, havia um distanciamento entre o teórico propalado e a prática vivenciada. (ibidem, p.14)

A continuação das análises permitiu tecer uma malha teórica para explicar o trabalho docente, isto é, um trabalho que está submetido à fragmentação, à hierarquização, à desqualificação e, consequentemente, à alienação se evidenciava "a partir do momento em que o pensamento intelectual do professor vai sendo eliminado progressivamente e sendo substituído pela execução repetitiva das funções e pela engrenagem do sistema" (ibidem, p.15). Nesse processo de fragmentação o professor torna-se um especialista da disciplina que leciona e não estabelece relações ou mediações com a realidade social nem com as demais disciplinas. No entanto, para Duarte (2001), um dos autores que fundamentam a pesquisa, o trabalho do professor diferencia-se de outros tipos de trabalho, ou seja, em outros tipos de trabalho o produto não necessariamente é prejudicado pela alienação do trabalhador, mas no trabalho do professor o produto é necessariamente afetado pela alienação do trabalhador. Para fundamentar essa análise buscou-se a seguinte passagem de autoria de Duarte (2001, p.56):

Nesse caso, a alienação do trabalhador perante o processo gerará também a alienação no que se refere ao produto, no caso, à formação do indivíduo educando. Assim, se o trabalho educativo se reduzir, para o educador, a um simples meio para a reprodução de sua existência, para a reprodução de sua cotidianidade alienada, esse trabalho não poderá se efetivar enquanto mediação consciente entre o cotidiano do aluno e a atuação desse aluno nas esferas não-cotidianas da atividade social. A atividade educativa se transformará, também ela, numa cotidianidade alienada, que se relacionará alienadamente com a reprodução da prática social. 
Em decorrência dessas condições de trabalho estabelece-se uma relação de alheamento entre a atividade do professor e sua individualidade, criando-se grandes obstáculos ao desenvolvimento de sua análise crítica tanto da prática pedagógica quanto das concepções nas quais se apoia para realizar essa prática no dia a dia escolar. Em outras palavras, dificilmente sua prática e o pensamento que a acompanha elevam-se acima da espontaneidade própria da rotina cotidiana.

A atomização do trabalho pedagógico inibe as forças intelectuais do professor, já que a produção intelectual, o conhecimento, concentra-se a serviço do capital e confronta-se com o trabalhador como força estranha e dominadora; a mecanização do trabalho docente expropria o saber do professor sobre suas ações pedagógicas, tornando-o incapaz de pensá-lo e concebê-lo na sua totalidade; a desqualificação docente priva-o do debate das grandes questões sociais: salários, desemprego, guerras, transformando o espaço escolar em espaço do silêncio, da aceitação e do conformismo; a forma como o sistema educacional atende às necessidades do capital, obriga o professor a um trabalho cansativo, apático, indiferente, condicionando-o a produzir algo que lhe permita ganhar a vida. Quando o sistema exige mudanças de concepções, de metodologias - e isto ocorre, quase sempre, a cada mudança de governo - do educador exige-se a mudança de sua prática pedagógica e o cumprimento da nova ordem estabelecida. (Francioli, 2005, p.48)

Por um lado, se pensarmos que esse trabalho está condicionado à automatização e mecanização, chegaremos à conclusão de que o professor, sujeito a essa situação, estaria mutilado e excluído de qualquer possibilidade de emancipação humana. Por outro, ancorados nos próprios fundamentos da literatura materialista histórica e dialética, encontramos as possibilidades de superação dessa situação adversa, por meio da inserção do trabalho educativo na luta social pela emancipação dos seres humanos em relação à dominação pelo capital:

No trabalho docente, não será fácil realizar esta emancipação; afinal a sociedade capitalista está organizada de forma a não permitir uma 
visão clara do todo, já que todos os sentidos físicos e mentais do homem estão subordinados ao sentido do "ter". Diante de tal realidade, como superar a alienação? Kosik (2003, p.24) afirma que somente destruindo a pseudoconcreticidade será possível a "[...] criação da realidade concreta e a visão da realidade, da sua concreticidade [...]”. Isto significa que, para se compreender a realidade - o mundo real, é necessário que o homem compreenda o mundo da práxis humana, isto é, o mundo onde as coisas, as relações e seus significados são considerados produtos do homem social e de sua humanização. Somente pelo pensamento dialético, ou seja, pelo pensamento crítico é que o homem se propõe a compreender as coisas em si e a transformar a realidade. Isso pode ocorrer de maneira sistemática quando o homem for capaz de perguntar como é possível compreender a realidade e desvendar o mundo real. (ibidem, p.62-3)

Essa possibilidade de emancipação não significa deixar de ser alienado, ${ }^{4}$ mas significa colocar-se criticamente diante da prática social. Para isso, é imprescindível que o trabalho educativo seja um instrumento de transformação social, a partir da apropriação do saber historicamente acumulado como condição para a superação dos limites impostos pela sociedade burguesa ao exercício da liberdade.

Nesse sentido, espera-se que o professor, como sujeito, que não reproduz apenas o conhecimento, possa fazer do seu próprio trabalho de sala de aula um espaço de práxis docente e de transformação humana. É na ação refletida e no redimensionamento da sua prática que o professor pode ser agente de mudança na escola e na sociedade. E uma ação pedagógica revolucionária implica conhecer os elementos repressivos implícitos nos espaços sociais, rompendo com a ignorância do saber e lutando pela igualdade real entre os homens, tendo como ponto de partida a prática social. (ibidem, p.105)

4 Afirmar que não é possível a nenhum indivíduo deixar de ser alienado na sociedade capitalista não equivale a afirmar que a alienação seja inerente à condição humana, mas sim que sua plena superação é possível somente com o fim das sociedades de classes. 
Chegar a essas considerações demandou muitos estudos, análises e reflexões, mas como já relatei no início desta reflexão, o mestrado foi um divisor de águas na minha vida profissional e pessoal e, ao concluí-lo, minhas análises sobre a educação escolar tomaram uma outra dimensão. Como continuava trabalhando com a educação básica, observando diariamente a pouca aprendizagem dos alunos e acompanhando a publicação dos resultados dos programas oficiais de avaliação, uma questão começou a inquietar-me. Por que grande parte das crianças, que terminavam as séries iniciais do Ensino Fundamental, apresentava tantas dificuldades na leitura e na escrita? O que estava acontecendo com o processo de alfabetização? Eu, com certeza, conhecia muito bem como se alfabetizava, conhecia os métodos, os livros didáticos adotados, os cursos de formação de professores alfabetizadores, então, por que isso me incomodava? A resposta era clara, em pouco tempo a encontrei, eu havia mudado completamente minha compreensão de educação escolar e de sociedade. Mudara tanto minha compreensão das concepções pedagógicas que influenciavam, de uma forma ou de outra, a prática nas séries iniciais do Ensino Fundamental, como também mudara minha compreensão das relações entre a educação escolar e a sociedade capitalista. Agora o foco era outro: diante do conhecimento dos motivos de tanto fracasso educacional, o que era possível fazer? Era possível discutir uma proposta de educação que se opusesse às que estavam postas e referendadas pelos programas nacionais de educação. Isso não seria novidade, afinal temos vários teóricos que já discutem a educação a partir da teoria do materialismo histórico dialético.

O fato é que tudo isso me levou a pensar na pesquisa para o doutorado. Assim, resolvi que meus estudos teriam como foco central a alfabetização, especificamente o ensino da escrita, identificando que na perspectiva teórica por mim adotada muito pouco se tinha produzido. Para superar as marcas da teoria construtivista, adotada hegemonicamente na alfabetização brasileira desde a década de 1980, era preciso propor uma pesquisa ancorada por teóricos que sustentam seus estudos na perspectiva do materialismo histórico dialético. No terreno dos fundamentos psicológicos da educação, 
uma das contribuições mais significativas para a pedagogia marxista vem dos estudos e pesquisas realizados por Vigotski e seus colaboradores. Dessa forma, tendo como princípio a teoria histórico-cultural, iniciei meus estudos, que ainda se encontram em fase primária, para entender as inquietações que tenho sobre a alfabetização das crianças.

O caminho que consegui percorrer até este momento foi, no entanto, desenvolvido por meio das leituras básicas indicadas para a produção da pesquisa e também pela análise, que não deixei de fazer, sobre os resultados da teoria construtivista no campo da alfabetização. É preciso esclarecer que o foco recaiu sobre a teoria construtivista, mas que essa teoria faz parte do que Duarte (2006, p.9) denominou as pedagogias do "aprender a aprender", constituídas pela pedagogia construtivista, pedagogia das competências, pedagogia do professor reflexivo, pedagogia dos projetos e pedagogia do multiculturalismo:

O lema "aprender a aprender" passa a ser vigorado nos meios educacionais, pois preconiza que à escola não caberia a tarefa de transmitir o saber objetivo, mas sim a de preparar os indivíduos para aprenderem aquilo que deles for exigido pelo processo de sua adaptação às alienantes relações sociais que presidem o capitalismo contemporâneo. A essência do lema "aprender a aprender" é exatamente o esvaziamento do trabalho educativo escolar, transformandoo num processo sem conteúdo. Em última instância o lema "aprender a aprender" é a expressão, no terreno educacional, da crise cultural da sociedade atual.

As análises dessas pedagogias resultaram em alguns textos que foram produzidos ao longo do ano 2009. O primeiro texto, elaborado como parte da avaliação da disciplina Teorias Pedagógicas, Trabalho Educativo e Sociedade, ministrada pelo Prof. Dr. Newton Duarte no segundo semestre de 2008 no Programa de Pós-Graduação em Educação Escolar da Universidade Estadual Paulista (Unesp) - Araraquara/SP, intitulado "Os mecanismos de avaliação da alfabetização sob a ótica das pedagogias do 'aprender a aprender'” (Francioli, 2009), foi apresentado no IV Congresso Internacional de Psicologia 
(CIPsi) e buscou analisar a "Provinha Brasil" " que foi instituída como um instrumento nacional de avaliação do Ministério da Educação, desde 2007.

Foi possível constatar que a Provinha Brasil, considerada um teste, deveria ser aplicada para o aluno que estivesse cursando o segundo ano de escolarização do Ensino Fundamental. Composta por um kit de seis documentos, nossa análise centrou-se no caderno de Reflexões sobre a prática. Esse caderno traz várias informações, mas uma delas em especial explicita os objetivos desse instrumento de avaliação:

Outro aspecto importante sobre a Provinha Brasil é que a avaliação proposta diferencia-se das demais que vêm sendo realizadas no país pelo fato de fornecer respostas diretamente aos alfabetizadores e gestores da escola, reforçando, assim, uma de suas finalidades que é a de construir um instrumento pedagógico, sem fins classificatórios. Ela foi concebida a partir do pressuposto de que uma avaliação da fase inicial da alfabetização pode trazer para o professor e para o gestor da escola informações que vão contribuir para o aperfeiçoamento e a orientação das práticas pedagógicas. Apresenta-se, dessa forma, como instrumento que propiciará o redimensionamento da prática pedagógica do professor. A intenção desse documento é a de possibilitar o desenvolvimento de práticas pedagógicas que alcancem níveis mais satisfatórios de alfabetização e letramento do que aqueles apresentados atualmente nas escolas do país. (Brasil, s. d., p.6, grifos nossos)

À primeira vista, essas informações parecem importantes, afinal contribuiriam para que o professor repensasse sua prática pedagógi-

5 Na pagina do Inep, a Provinha Brasil é apresentada como uma avaliação diagnóstica do nível de alfabetização das crianças matriculadas no segundo ano de escolarização das escolas públicas brasileiras. Essa avaliação acontece em duas etapas, uma no início e a outra no término do ano letivo. A aplicação em períodos distintos possibilita aos professores e gestores educacionais a realização de um diagnóstico mais preciso que permite conhecer o que foi agregado na aprendizagem das crianças, em termos de habilidades de leitura dentro do período avaliado. 
ca, mas ao procurar no texto referências teóricas que encaminhariam a ação pedagógica do professor, não foi possível identificar nenhuma questão que fundamentasse sua prática educativa. Ao contrário, foi possível identificar que as orientações defendiam as ideias da resolução dos problemas pela prática, associando-se ao conhecimento tácito, ao conhecimento do cotidiano, desvinculado de qualquer conhecimento científico e vinculadas, na análise que fizemos, à pedagogia do professor reflexivo que tem como princípio a centralidade no conhecimento tácito. Como afirma Newton Duarte em seu artigo publicado nesta coletânea, a pedagogia do professor reflexivo fica restrita ao conhecimento-na-ação do aluno. Ou dito de outra forma:

Se as crianças e os jovens devem construir seus conhecimentos a partir das demandas de sua prática cotidiana, então a formação dos professores também deve seguir essa diretriz, pois o conhecimento decisivo para as decisões que o professor toma em sua atividade profissional não é aquele proveniente dos livros e das teorias, mas o conhecimento tácito que se forma na ação, no pensamento que acompanha a ação e no pensamento que pensa sobre o pensamento que acompanha a ação. Aprender a pensar e a tomar decisões acertadas diante de situações práticas problemáticas e imprevisíveis seria um dos maiores senão o maior objetivo da formação de professores. E o maior objetivo do trabalho do professor seria contribuir para que seus alunos também aprendam a pensar e a resolverem problemas postos por suas práticas cotidianas. Em suma, tudo gira em torno do aprender a aprender e do aprender fazendo. ${ }^{6}$

É preciso esclarecer que a crítica a essa centralidade que o conhecimento tácito adquire na teoria do professor reflexivo não significa desconsiderar a prática do professor, mesmo porque isso iria na contramão da teoria aqui adotada, que compreende que o desenvolvimento humano ocorre pela relação entre teoria e prática. O que se questiona é o esvaziamento teórico nessa proposta de avaliação. Se a

6 Confira o Capítulo 2 deste livro. 
"Provinha Brasil" visa contribuir para o aperfeiçoamento e orientações da prática pedagógica, sob qual perspectiva teórica se embasará? Num outro momento constatei que as informações afirmavam:

A Provinha Brasil só irá contribuir com o professor se ele compreender as respostas dos alunos. Para isso, o professor necessita analisar as respostas e "[...] transformá-las em 'dados observáveis' que permitam inferir hipóteses ou conflitos cognitivos, subjacentes a cada resposta ou a desempenhos alternativos, em relação ao esperado [...]” (BRASIL, 2008). O subitem ainda informa que, de posse dos dados, o professor deve fazer intervenções para favorecer a retomada de capacidades ainda não desenvolvidas na criança. Os elaboradores da provinha Brasil, consideram que ao fazer essas intervenções o professor estará mediando com o aluno e numa postura investigativa "[...] ele transforma a dificuldade em fonte de informação sobre o que a criança pensa sobre a escrita ou sobre o que ela acha que a escrita representa [...]" (BRASIL, 2008). (Francioli, 2009, p.5-6).

Depois da análise de vários itens que continuavam tratando da avaliação dos alunos de alfabetização, passei a analisar o item que tratava da articulação da "Provinha Brasil" com os programas de formação continuada do Ministério da Educação (MEC). Os fragmentos que apresentarei a seguir não deixam dúvidas de que os pressupostos teóricos que fundamentam a formação nacional dos professores alfabetizadores estão respaldados nas pedagogias do "aprender a aprender".

Pode-se afirmar, portanto, que esse processo de escolha e uso de materiais fazem parte da formação continuada do professor, contribuindo para fazer dele um profissional cada vez mais reflexivo e autônomo; A reflexão sobre a prática docente tem como fim avaliar a necessidade de redimensionamento do trabalho, que vem atrelada à necessidade de elaboração de instrumentos adequados para o exercício dessa competência; A discussão dos pressupostos baseia-se na experiência e no saber, acumulados pelos professores alfabetizadores, e nos 
desafios que enfrentam cotidianamente e nas respostas que dão a esses desafios nas suas escolas. (Francioli, 2009, p.9, grifos do autor)

Diante dessas afirmações registradas nos cadernos da "Provinha Brasil”, fica patente que os conteúdos clássicos não estão sendo ensinados, que o mais importante é a prática vivenciada no dia a dia dos alunos, como se bastasse entender essa prática cotidiana para compreender as contradições da sociedade. Nesse sentido, considero pertinente fazer uma análise, tendo como referência o texto de Saviani (2005, p.107) que aborda claramente a relação entre a teoria e a prática:

Quando entendemos que a prática será tanto mais coerente e consistente, será tanto mais qualitativa, será tanto mais desenvolvida quanto mais consistente e desenvolvida for a teoria que a embasa, e que uma prática será transformada à medida que exista uma elaboração teórica que justifique a necessidade da sua transformação e que proponha as formas da transformação, estamos pensando a prática a partir da teoria...

Do ponto de vista educacional, esse posicionamento de Saviani contraria todas as perspectivas pedagógicas, as quais tenho discutido ao longo deste trabalho, adotadas pelos órgãos oficiais para a educação brasileira. Por isso, durante as atividades da pesquisa, algumas inquietações me acompanharam: como é que essas pedagogias, especificamente o construtivismo, tornaram-se hegemônicas nas escolas? Só foi possível obter esse entendimento quando produzimos, em grupo, um texto que identificou alguns dados significativos que justificavam a adoção dessa teoria (Francioli et al., 2009). Esses dados foram levantados no Instituto Nacional de Estudos e Pesquisas Educacionais Anísio Teixeira (Inep), que demonstravam que o Brasil, no início da década de 1980, apresentava um índice de 25,9\% de analfabetos acima de 15 anos, isso significava um grande desafio para o governo, era preciso extinguir o analfabetismo. Nesse período, educadores brasileiros tiveram acesso à teoria sobre a psicogênese da 
língua escrita de Emilia Ferreiro e Ana Teberoski de base construtivista, que era resultado da pesquisa que essas educadoras realizaram na Argentina na década de 1970, época em que esse país apresentava índices de analfabetismo tão altos como no Brasil. A referida pesquisa justificava que o fracasso das crianças argentinas, no início da alfabetização, era resultado dos métodos tradicionais - sintético e analítico - adotados por longas décadas nas escolas daquele país. Para essas pesquisadoras a ênfase nesses métodos criou um ensino dicotômico, portanto era preciso repensar o ensino de alfabetização, descolando o eixo do ensino tradicional, fundamentado na rigidez dos métodos, dos manuais e dos recursos didáticos de como se deve ensinar, para a aprendizagem, ou seja, como de fato a criança aprende. Nascia naquele momento uma proposta de alfabetização que afirmava considerar a criança como um sujeito cognoscente.

O sujeito que busca adquirir conhecimentos, o sujeito que a teoria de Piaget nos ensinou a descobrir. O que quer dizer isto? O sujeito que conhecemos através da teoria de Piaget é aquele que procura ativamente compreender o mundo que o rodeia e trata de resolver as interrogações que este mundo provoca. Não é um sujeito o qual espera que alguém que possui um conhecimento o transmita a ele por um ato de benevolência. É um sujeito que aprende basicamente através de suas próprias ações sobre os objetos do mundo e que constrói suas próprias categorias de pensamento ao mesmo tempo que organiza seu mundo. (Ferreiro \& Teberoski, 1999, p.29)

A realidade educacional brasileira assemelhava-se à da Argentina, então, segundo a argumentação construtivista, estava explicado o fracasso obtido, pelas crianças brasileiras, nas séries iniciais do Ensino Fundamental. "É nesse contexto que a pesquisa de Mortatti (2000) constata que foi por meio da Coordenadoria de Estudos e Normas Pedagógicas (CENP) da Secretaria de Estado da Educação de São Paulo (SEE), que a teoria construtivista chegou ao Brasil” (Francioli et al., 2009, p.3). O grupo de educadores que compunha a Cenp iniciava um programa de capacitação para os professores 
disseminando a nova proposta da psicogênese da língua escrita. Essas capacitações eram realizadas "por meio de fascículos impressos pela CENP, programas televisivos e posteriormente por meio de seminários, palestras, publicações de obras etc. $\mathrm{O}$ construtivismo como fundamentação teórica é oficialmente assumido pelo Estado de São Paulo" (ibidem, p.3) e, em 1988 a Fundação para o Desenvolvimento da Educação (FDE) do Ministério da Educação, implementa essa teoria em todo território nacional, por meio dos cursos de formação dos professores e dos seminários e cursos de capacitação. Essa teoria é assumida oficialmente pelo Ministério da Educação em 1996 com a implantação dos PCN. A essa altura, a retórica construtivista já havia se difundido nacionalmente.

Apesar de todo empenho das políticas públicas brasileiras para que se erradicasse o analfabetismo no país, chegamos ao século XXI com uma taxa altíssima de analfabetos para um país em que o discurso é o de desenvolvimento econômico. Um estudo publicado pelo Ministério da Educação, intitulado "Mapa do analfabetismo no Brasil” (Brasil, 2003) demonstra que "O Brasil possui cerca de 16 milhões de analfabetos com 15 anos ou mais e 30 milhões de analfabetos funcionais, conceito que define as pessoas com menos de quatro anos de estudo” (Instituto Nacional..., 2003). Mesmo que passados sete anos, os resultados das avaliações oficiais como a do Sistema de Avaliação da Educação Básica (Saeb) e a Prova Brasil continuam preocupantes por demonstrarem índices de pouca aprendizagem e a não erradicação do analfabetismo.

Como já anunciei anteriormente, observando esses dados é que minha proposta de pesquisa voltou-se para a questão do ensino da escrita na alfabetização. Enquanto para a teoria construtivista existem processos de aprendizagem do sujeito que não dependem dos métodos, assim justificado por Ferreiro \& Teberoski (1999, p. 31, grifo das autoras), "o método (enquanto ação específica do meio) pode ajudar ou frear, facilitar ou dificultar; porém não pode criar aprendizagem. A obtenção de conhecimento é resultado da própria atividade do sujeito...", para a teoria histórico-cultural a criança tem que ser ensinada e é na escola que esse ensino deve ocorrer de maneira 
sistematizada. "Porque na escola a criança não aprende o que sabe fazer sozinha, mas o que ainda não sabe e lhe vem a ser acessível em colaboração com o professor e sob sua orientação..." (Vigotski, 2001, p.331, grifos nossos). De fato, quando as crianças vão para a escola é para aprender algo que ainda não dominam, como a leitura, a escrita, os cálculos, por isso precisam de alguém que as ensine.

Como se pode notar, são duas teorias que têm princípios opostos em relação ao desenvolvimento da escrita na criança. Essas oposições podem ser identificadas quando, ambas, discutem a alfabetização: para as pesquisadoras construtivistas a escrita da criança passa por três grandes períodos regulares de evolução:

Distinção entre o modo de representação icônico e o não-icônico; a construção de formas de diferenciação (controle progressivo das variações sobre os eixos qualitativos e quantitativos) e a fonetização da escrita (que se inicia com um período silábico e culmina no período alfabético). (Ferreiro, 2001, p.19)

Para a autora, contudo, esses períodos de evolução regular não precisam ser ensinados porque a criança não "aprende só quando é submetida a um ensino sistemático...” (ibidem, p.17), mas aprende sozinha, porque "são seres que ignoram que devem pedir permissão para começar a aprender..." (ibidem). A disseminação desse entendimento teórico resultou em um ensino fragilizado, centrando a ação no aprendiz, uma vez que se defendeu uma prática pedagógica na qual supostamente a criança seria um sujeito ativo, que, ao procurar compreender a linguagem à sua volta, "formula hipóteses, busca regularidades, coloca à prova suas antecipações e cria sua própria gramática" (que não é simples cópia deformada do modelo adulto, mas sim, criação original)..." (Ferreiro \& Teberoski, 1999, p.24). Em razão desse entendimento, a criança passa a ser considerada a construtora do seu próprio conhecimento a partir do que vê, sente e seleciona o que está à sua volta, porque por trás da criança que está se alfabetizando há um sujeito cognoscente, ou seja, uma criança que vive em ambientes letrados, que pensa, que interpreta, que age sobre 
o real. Para essas autoras, essa criança aprende basicamente pelas suas próprias ações ao interagir com os objetos à sua volta, por isso, não precisa esperar até os 6 ou 7 anos por um professor que vai ensiná-la. O que vale é a intenção da criança que quer aprender, cabendo a ela interpretar a sua própria escrita e não a dos outros.

Diferentemente do que afirmam as pesquisadoras construtivistas, para os pesquisadores da teoria histórico-cultural, que como Luria (2006, p.144-5) estudaram a pré-história da escrita,

a escrita pode ser definida como uma função que se realiza, culturalmente, por mediação. A condição mais fundamental exigida para que a criança seja capaz de tomar nota de alguma noção, conceito ou frase é que algum estímulo, ou insinuação particular, que, em si mesmo, nada tem que ver com esta idéia, conceito ou frase, é empregado como um signo auxiliar cuja percepção leva a criança a recordar a idéia, etc., à qual ele se refere. O escrever pressupõe, portanto, a habilidade para usar alguma insinuação (por exemplo, uma linha, uma mancha, um ponto) como signo funcional auxiliar, sem qualquer sentido ou significado em si mesmo, mas apenas com uma operação auxiliar. (grifo do autor)

Considerando essa afirmação, Luria (2006) constatou que a escrita tem diversos estágios de desenvolvimento e que a criança, antes de entrar na escola, já assimilou algum desses estágios considerados fundamentais para a aquisição da linguagem escrita. Luria denomina esses estágios de pré-história da escrita classificando-os em: a) estágio dos rabiscos - isto significa que nesse estágio a criança tenta imitar a escrita dos adultos fazendo rabiscos sem significado funcional, por isso a relação da criança com os rabiscos é puramente externa, ela não tem consciência de que os rabiscos podem ajudá-la a lembrar-se do que lhe foi dito para escrever; b) estágio da escrita não diferenciada-a criança utiliza os rabiscos não para ler, mas para lembrar-se do que lhe foi dito, por isso é uma fase instável como instrumento auxiliar de memória e a criança depois de algum tempo pode esquecer o significado do que registrou; c) estágio da escrita diferenciada - nessa 
fase a escrita da criança ainda é confusa, mas a ideia de usar desenhos enquanto registra pode ser um meio que ela utiliza para lembrar-se do que escreveu. É um estágio em que a criança descobre sua própria maneira de registrar. Luria (2006, p.188) confirma que o processo de alfabetização "envolve a assimilação dos mecanismos da escrita simbólica culturalmente elaborada e o uso de expedientes simbólicos para exemplificar e apressar o ato de recordação...”.

Para Vigotski (2001), um ensino adequado da linguagem escrita e sua consequente apropriação pela criança são processos constitutivos de uma atividade extremamente complexa que provoca transformações no desenvolvimento cultural e psíquico da criança. Ao dominar esse sistema simbólico, a criança cria sinapses essenciais para outras formas elaboradas de pensamento. "A criança se desenvolve na medida em que aprende...” (ibidem, p.301). A língua escrita muda os modos de funcionamento da percepção, da memória e do pensamento; assim, ao apropriar-se da língua escrita, a criança se apropria das técnicas oferecidas por sua cultura. Esse sistema simbólico é considerado um dos instrumentos culturais mais bem elaborados pela humanidade, é um produto, mas ao mesmo tempo um elemento importante para o próprio desenvolvimento do homem.

Se estamos tratando do ensino, também precisamos tratar de quem ensina, e quem ensina deve ter "o domínio dos instrumentos de elaboração e sistematização...” (Saviani, 2005, p.77), ou dito de outra forma, o professor que alfabetiza deverá conhecer as particularidades da língua escrita que constituem as características essenciais para o desenvolvimento do psiquismo humano, deverá estruturar um ensino escolar organizado em conteúdos e métodos que permitam às crianças assimilarem com êxito os saberes produzidos historicamente. "O povo precisa da escola para ter acesso ao saber erudito, ao saber sistematizado e, em conseqüência, para expressar de forma elaborada os conteúdos da cultura popular correspondente aos seus interesses" (ibidem, p.80, grifo nosso). A educação escolar tem o compromisso de desempenhar um ensino que propicie "a aquisição dos instrumentos que possibilitam o acesso ao saber elaborado (ciência), bem como o próprio acesso aos rudimentos desse saber..." 
(ibidem, p.15). Isso significa que o acesso ao saber elaborado historicamente pela humanidade requer uma atividade sistemática de apropriação do conhecimento, diferenciando-se de formas espontâneas de aprendizagem que podem se mostrar válidas para o saber popular que se forma na vida cotidiana. Para isso, a educação escolar deve desempenhar o papel social que lhe cabe, ou seja, ensinar, por meio dos conteúdos, o conhecimento científico, possibilitando que os alunos desenvolvam autonomia para compreender e transformar sua prática social.

Essa perspectiva contraria os posicionamentos teóricos que alimentam as exigências da sociedade capitalista da adaptação, do descartável, do imediato, da profunda alienação humana. Comolutar contra essa política da alienação? Como superar a alienação produzida pelo capitalismo? Sabemos que numa sociedade capitalista, em meio à luta de classes, todo ensino é alienante, fragmentado, mas a nossa luta deve ser por uma escola que tenha a função específica de ensinar os conteúdos científicos, artísticos e filosóficos clássicos, que possam ser incorporados pelos indivíduos a uma concepção de mundo adequada a uma prática social que produza transformações radicais. Como afirma Saviani (2005, p.98), "é preciso resgatar a importância da escola e reorganizar o trabalho educativo, ${ }^{7}$ levando em conta o problema do saber sistematizado, a partir do qual se define a especificidade da educação escolar". Cumpre assinalar que esse saber necessita de uma pedagogia crítica que se rebele contra as pedagogias que se mantêm atreladas a projetos políticos e econômicos neoliberais.

\section{Referências bibliográficas}

BRASIL. Ministério da Educação. Instituto Nacional de Estudos e Pesquisas Educacionais Anísio Teixeira. Provinha Brasil: reflexões sobre a prática. S. d. Disponível em: <http://provinhabrasil.inep.gov.br/

7 Saviani (2005, p.13) define que "o trabalho educativo é o ato de produzir, direta e intencionalmente, em cada indivíduo singular, a humanidade que é produzida historicamente e coletivamente pelo conjunto dos homens...". 
images/stories/downloads/2_kit_2008/reflexoes_sobre_a_pratica\%20 2-2008.pdf>. Acesso em: 3 dez. 2008.

. Programa de Formação de Professores Alfabetizadores: documento de apresentação. Brasília: Ministério da Educação, Secretaria da Educação Fundamental, 2001.

Mapa do Analfabetismo no Brasil. Brasília: Ministério da Educação, 2003. Disponível em: <http://www.oei.es/quipu/brasil/estatísticas/ analfabetismo2003.pdf>. Acesso em: 23 mar. 2009.

DUARTE, N. Educação escolar, teoria do cotidiano e a escola de Vigotski. 3.ed. Campinas: Autores Associados, 2001.

Vigotski e o "aprender a aprender": crítica às apropriações neoliberais e pós-modernas da teoria vigotskiana. 4.ed. Campinas: Autores Associados, 2006.

FERREIRO, E. Reflexões sobre alfabetização. 24.ed. São Paulo: Cortez, 2001. FERREIRO, E.; TEBEROSKI, A. Psicogênese da língua escrita. Porto Alegre: Artmed, 1999.

FRANCIOLI, F. A. S. Profissão docente: uma análise dos fatores intervenientes na prática educativa. Ponta Grossa, 2005. Dissertação (Mestrado) - Faculdade de Educação, Universidade Estadual de Ponta Grossa.

Os mecanismos de avaliação da alfabetização sob a ótica das pedagogias do "aprender a aprender". In: IV CONGRESSO INTERNACIONAL DE PSICOLOGIA (CIPSI): 26 a 29 de maio de 2009. Anais... Maringá, PR: Universidade Estadual de Maringá (UEM), 2009. 1 CD-ROM.

FRANCIOLI, F. A. S. et al. A hegemonia do lema "aprender a aprender" na alfabetização contemporânea. 2009. Disponível em: <http://www. histedbr.fae.unicamp.br/acer_histedbr/seminario/seminario8/trabalhos.html>. Acesso em: 17 abr. 2010.

INSTITUTO NACIONAL DE ESTUDOS E PESQUISAS EDUCACIONAIS ANÍSIO TEIXEIRA. Estudo detalha situação do analfabetismo no País. Brasília: Ministério da Educação, 4 de junho de 2003. Disponível em: <http://www.inep.gov.br/imprensa/noticias/outras/ news03_19.htm>. Acesso em: 23 mar. 2010.

LURIA, A. R. O desenvolvimento da escrita na criança. In: VIGOTSKI, L. S.; LURIA, A. R.; LEONTIEV, A. N. Linguagem, desenvolvimento e aprendizagem. 10.ed. São Paulo: Ícone, 2006. p.143-89.

NOVA ESCOLA. São Paulo, ano XI, n.97, out. 1996.

SAVIANI, D. Pedagogia histórico-crítica: primeiras aproximações. 9.ed. Campinas: Autores Associados, 2005. 
VIGOTSKI, L. S. A construção do pensamento e da linguagem. São Paulo: Martins Fontes, 2001.

WEISZ, T. Apresentação. In: FERREIRO, E; TEBEROSKI, A. Psicogênese da língua escrita. Porto Alegre: Artmed, 1999. p.VII-IX. 


\title{
9
}

\section{O PAPEL DO PROFESSOR E DO ENSINO NA EDUCAÇÃO INFANTIL: A PERSPECTIVA DE VIGOTSKI, LEONTIEV E ELKONIN}

\author{
Juliana Campregher Pasqualini ${ }^{1}$
}

O presente texto resulta de nossa pesquisa de mestrado, um estudo de natureza teórico-conceitual que teve como objetivo investigar e analisar as relações entre desenvolvimento infantil e ensino na faixa etária de 0 a 6 anos $^{2}$ em obras selecionadas de autores da psicologia histórico-cultural. $\mathrm{O}$ acervo pesquisado incluiu obras de L. S. Vigotski, A. N. Leontiev e D. B. Elkonin, nas quais buscamos identificar a concepção geral de desenvolvimento infantil e as especificidades desse período do desenvolvimento sobre as quais possa operar o ensino escolar.

Diante da constatação da hegemonia na literatura contemporânea dedicada ao segmento da Educação Infantil de um ideário antiescolar, que tem como um de seus pilares a negação do ato de ensinar, nossa investigação pautou-se pela hipótese de que a produção teórica dos

1 Psicóloga, mestre e doutora em Educação Escolar pelo Programa de Pós-Graduação em Educação Escolar da Universidade Estadual Paulista (Unesp), campus de Araraquara. É membro do Grupo de Pesquisa "Estudos marxistas em educação".

2 A pesquisa teórica aqui relatada foi desenvolvida em momento anterior às mudanças na legislação educacional que implementaram o Ensino Fundamental de 9 anos, fato que nos levou a optar pela manutenção no presente texto da referência original à faixa etária de 0 a 6 anos. 
autores da psicologia histórico-cultural sustenta a defesa do ensino como elemento fundante do trabalho do professor que atua junto à referida faixa etária.

Apresentaremos alguns dos resultados obtidos na pesquisa e suas principais conclusões, tendo como foco a discussão sobre o papel do educador e do ensino na perspectiva de Vigotski, Leontiev e Elkonin. Dessa forma, buscaremos inicialmente situar essa discussão na literatura contemporânea que versa sobre a educação da criança pequena, apresentando, em seguida, a concepção da psicologia histórico-cultural sobre o desenvolvimento infantil, as características desse processo na faixa etária de 0 a 6 anos e as conclusões alcançadas a respeito do ensino e do papel do professor que atua junto a essa faixa etária.

\section{O ideário antiescolar na Educação Infantil}

A literatura contemporânea voltada à educação de crianças de $0 \mathrm{a}$ 6 anos apresenta a partir da década de 1990 um intenso debate acerca da especificidade do trabalho pedagógico junto a essa faixa etária. Verifica-se a tentativa de se delinear uma identidade própria para o segmento da Educação Infantil, que foi historicamente atrelado a finalidades extrínsecas, ora compreendido como equipamento de caráter assistencial-custodial (especialmente no caso das creches), ora como estratégia de prevenção do fracasso escolar, preparação para o Ensino Fundamental ou mesmo sua antecipação.

As respostas oferecidas pelos pesquisadores à questão da especificidade da Educação Infantil giram hoje fundamentalmente em torno de dois eixos: o binômio cuidar-educar ${ }^{3}$ e a perspectiva antiescolar, elementos fundantes da chamada pedagogia da infância (ou

3 O binômio cuidar-educar expressaria o objetivo principal do trabalho pedagógico junto à faixa etária atendida pela educação infantil (Faria, 2005; Cerisara, 2004; Rocha, 1999) e aparece na literatura como algo que marcaria a identidade desse segmento educacional, concepção essa que se mostra presente também na documentação oficial. 
pedagogia da Educação Infantil). Entende-se, nessa perspectiva, que a especificidade da educação da criança pequena implica a negação e o rompimento dos laços com o modelo escolar de atendimento educacional. Entende-se ainda que o ensino não deve fazer parte do atendimento ofertado à criança até os 6 anos. Para essa perspectiva teórica, a Educação Infantil "faz parte da educação básica, mas não tem como objetivo o ensino e, sim, a educação das crianças pequenas" (Cerisara, 2004, p.8). Nesse sentido, conforme Cerisara, o foco, na Educação Infantil, não estaria nos processos de ensino-aprendizagem, mas nas chamadas relações educativo-pedagógicas. O ensino, assim, é negado quando se trata da Educação Infantil, mas assumido como objeto fundamental da escola:

Portanto, enquanto a escola tem como sujeito o aluno, e como o objeto fundamental o ensino nas diferentes áreas, através da aula; a creche e a pré-escola têm como objeto as relações educativas travadas num espaço de convívio coletivo que tem como sujeito a criança de 0 a 6 anos de idade. (Rocha, 1999, p.70, grifos nossos)

Nessa direção, o parecer da Associação Nacional de Pós-Graduação e Pesquisa em Educação (ANPEd, 1998) sobre o Referencial Curricular Nacional para a Educação Infantil afirma que o uso do termo ensino no documento representa um retrocesso e um desrespeito às especificidades do segmento:

Ao insistir no uso da palavra ensino ao longo de todo o documento, o Referencial retrocede em relação a todo um debate desenvolvido no país, o qual já obteve consensos importantes a respeito das características específicas que deve assumir a educação e o cuidado da criança pequena em contextos coletivos. (ibidem, p.94, grifos nossos)

As relações educativo-pedagógicas, que, segundo Cerisara (2004), deveriam ser o objeto das instituições de Educação Infantil, são definidas como mais amplas que o processo de ensino-aprendizagem (Rocha, 1999), o qual é compreendido como processo que 
privilegiaria o aspecto cognitivo. As relações educativo-pedagógicas abarcariam, por sua vez, além da dimensão cognitiva, as dimensões "expressiva, lúdica, criativa, afetiva, nutricional, médica, sexual" (ibidem, p.65). A autora esclarece que o termo educacional-pedagógico busca explicitar "as diferentes dimensões desta relação no plano político, institucional e pedagógico propriamente dito (com caráter de intencionalidade definida, planejada e sistematizada de ação junto à criança)..." (ibidem).

Assim, nessa perspectiva o ensino parece ser compreendido como processo voltado (exclusivamente) ao aspecto cognitivo e prejudicial ao desenvolvimento da criança na primeira infância e idade pré-escolar. Portanto, nessa faixa etária o professor não deve ensinar, mas limitar-se a acompanhar, favorecer e estimular o desenvolvimento infantil - ou, ainda, a seguir as crianças, conforme expressão do educador italiano Loris Malaguzzi (Arce, 2004).

Como, porém, analisar tais proposições na perspectiva da psicologia histórico-cultural? Como já mencionado, partimos da hipótese de que os postulados teóricos de Vigotski, Leontiev e Elkonin sustentam a defesa do ensino como elemento fundante do trabalho do professor que atua junto à criança de 0 a 6 anos. Sendo assim, como compreender o papel e a natureza do ensino na perspectiva desses autores? Qual a relação entre ensino e desenvolvimento? Qual deve ser o papel do professor que trabalha com a criança na primeira infância e idade pré-escolar? Para responder a esses questionamentos, nos reportaremos ao conhecimento produzido por esses autores sobre o processo de desenvolvimento infantil.

\section{A concepção histórico-cultural do desenvolvimento infantil}

Vigotski inaugura uma nova abordagem do processo de desenvolvimento infantil, desvelando o papel da cultura e das relações sociais no desenvolvimento do psiquismo da criança e afastando-se, assim, do maturacionismo, do ambientalismo e do interacionismo. 
O autor refuta a compreensão do desenvolvimento como um processo estereotipado de crescimento e maturação de potências internas previamente dadas. Tal concepção remeteria à analogia entre o desenvolvimento infantil e os processos de crescimento das plantas, reduzindo o complexo processo de desenvolvimento psíquico a determinações quase que exclusivamente biológicas. Ao contrário, Vigotski (1995, p.34) revela e explicita a subordinação dos processos biológicos ao desenvolvimento cultural, demonstrando que "a cultura origina formas especiais de conduta, modifica a atividade das funções psíquicas, edifica novos níveis no sistema do comportamento humano em desenvolvimento". Para Vigotski(1996, p.264): "Não se pode aplicar à teoria do desenvolvimento infantil a mesma concepção do meio que se adota na biologia a respeito da evolução das espécies [...] a realidade social é a verdadeira fonte de desenvolvimento...".

Vigotski (1995) postula que o desenvolvimento infantil constitui uma unidade dialética entre duas linhas genéticas - o desenvolvimento biológico e o cultural. Trata-se, portanto, de um processo único de formação biológico-social da personalidade da criança, mas não de uma simples "mistura" entre o plano biológico e o social. No homem, o desenvolvimento cultural se sobrepõe aos processos de crescimento e maturação orgânica, pois na medida em que o desenvolvimento orgânico se produz em um meio cultural, ele converte-se em um processo biológico sócio-historicamente condicionado.

Dessa forma, a perspectiva histórico-cultural contrapõe-se radicalmente a uma visão naturalizante do desenvolvimento infantil, isto é, indica que não é possível compreender o desenvolvimento infantil como um processo natural, que se desenrola de forma espontânea, como resultado de leis naturais. Isso significa que o desenvolvimento psíquico não percorre um caminho natural, determinado pelas leis da natureza. Vigotski (1995) afirmou que é a sociedade - e não a natureza - que deve figurar em primeiro plano como fator determinante da conduta e do desenvolvimento humanos. Isso porque o desenvolvimento cultural incorpora, transforma e supera a dimensão natural do desenvolvimento da criança. 
Nesse sentido, um aspecto fundamental da perspectiva de Vigotski, Leontiev e Elkonin é a historicidade. Vigotski (2001a, p.22) criticava a tentativa da psicologia de encontrar características e leis universalmente válidas para o desenvolvimento infantil e considerava inteiramente equivocado o ponto de vista das diversas vertentes da psicologia vigentes em sua época que supunham equivalentes e idênticos o funcionamento psíquico e a concepção de mundo de "uma criança européia de família culta dos dias de hoje e uma criança de alguma tribo primitiva, [...] da criança da Idade da Pedra, da Idade Média ou do século XX...”. Na análise do autor, a psicologia tradicional estudava a criança e o desenvolvimento de suas funções psíquicas in abstracto, isto é, à margem de seu meio social e cultural.

Assim, o desenvolvimento infantil não é determinado por leis naturais universais, mas encontra-se intimamente ligado às condições objetivas da organização social, o que aponta para a impossibilidade de se estabelecer estágios do desenvolvimento psicológico que se sucedam em uma ordem fixa e universal, válida para toda e qualquer criança em todo e qualquer contexto e a qualquer tempo. Segundo Leontiev (2001a, p.65-6 ), nem o conteúdo dos estágios nem sua sequência no tempo são universais e imutáveis, pois dependem das condições históricas concretas nas quais se processa o desenvolvimento da criança: "não é a idade da criança, enquanto tal, que determina o conteúdo de estágio do desenvolvimento; os próprios limites de idade de um estágio, pelo contrário, dependem de seu conteúdo e se alteram pari passu com a mudança das condições histórico-sociais".

De acordo com Leontiev (2001a) e Elkonin (1987b), é necessário considerar-se, na investigação do desenvolvimento infantil, o vínculo entre criança e sociedade, ou o lugar que a criança ocupa no sistema das relações sociais em um determinado momento histórico. Na mesma direção, Vigotski (1996) afirma que a situação social de desenvolvimento, ou seja, a relação que se estabelece entre a criança e o meio que a rodeia (que é peculiar, específica, única e irrepetível em cada idade ou estágio do desenvolvimento), é o ponto de partida para todas as mudanças dinâmicas que se processarão no desenvolvimento durante uma determinada idade ou período, determinando 
"plenamente e por inteiro" as formas e a trajetória que permitem à criança adquirir novas propriedades da personalidade. ${ }^{4}$

Leontiev (2001a, p.63) postula que a situação objetiva ocupada pela criança no interior das relações sociais em cada período de seu desenvolvimento constitui um elemento fundamental para compreender o processo de desenvolvimento psíquico na ontogênese:

O que determina diretamente o desenvolvimento da psique de uma criança é sua própria vida e o desenvolvimento dos processos reais desta vida - em outras palavras: o desenvolvimento da atividade da criança, quer a atividade aparente, quer a atividade interna. Mas seu desenvolvimento, por sua vez, depende de suas condições reais de vida.

Diante do exposto, concordamos com Arce (2004) quando afirma que, em contraposição a uma visão idealizada da infância, Vigotski, Leontiev e Elkonin evidenciaram a estreita relação entre o desenvolvimento da criança e a sociedade na qual ela se insere, compreendendo as condições objetivas disponibilizadas à criança como um fator determinante de seu desenvolvimento.

\section{Cultura e desenvolvimento psíquico}

Embora Vigotski (1995) compreenda o desenvolvimento infantil como uma unidade entre as linhas de desenvolvimento biológico e cultural, a diferenciação entre os planos natural e cultural do desenvolvimento se faz necessária, em sua análise, para que não se incorra em uma interpretação biológica dos processos psicológicos superiores

4 A lei fundamental que rege a dinâmica das idades na perspectiva de Vigotski (1996) consiste em que as forças que movem o desenvolvimento da criança de uma idade a outra acabam por negar e destruir a própria base do desenvolvimento da idade anterior, determinando, como necessidade interna, o fim da situação social de desenvolvimento - o fim da etapa vigente do desenvolvimento em direção à etapa seguinte. 
humanos. Vigotski postula que a gênese das funções psicológicas exclusivamente humanas não é biológica, mas fundamentalmente cultural.

Conforme Pino (2000), podemos dizer, em linhas bem gerais, que o termo cultura na teoria vigotskiana refere-se à totalidade das produções humanas, isto é, a tudo aquilo que se contrapõe ao que é dado pela natureza, que resulta da ação criadora e transformadora do homem sobre a natureza. ${ }^{5}$ No processo de desenvolvimento histórico, como demonstram Vigotski \& Luria (1996), o homem modificou não apenas a natureza exterior, mas também (como condição e resultado dessa transformação) os modos e procedimentos de sua própria conduta. Segundo Vigotski (1995, p.85), "a cada etapa determinada no domínio das forças da natureza corresponde sempre uma determinada etapa no domínio da conduta, na subordinação dos processos psíquicos ao poder do homem". A transformação da natureza pelo homem implica também a transformação de sua própria natureza, emergindo, assim, historicamente, a partir da atividade social humana, novas formas de comportamento e novos processos psicológicos especificamente culturais.

Nesse sentido, Vigotski \& Luria (1996) afirmam que as funções psíquicas exclusivamente humanas são produto do desenvolvimento histórico do homem em sociedade:

Os processos psicológicos elementares - tais como reflexos, reações automáticas, associações simples, memória imediata etc. - são determinadas fundamentalmente pelas peculiaridades biológicas da psique; já os processos psicológicos superiores - tais como atenção voluntária, memorização ativa, pensamento abstrato, planejamento - nascem durante o processo de desenvolvimento cultural, representando uma forma de conduta geneticamente mais complexa e superior. (Facci, 2004, p.205)

5 Pino (2000) ressalta que essa conceituação é evidentemente insuficiente para explicar a natureza da cultura, sendo necessário, para tanto, analisar-se o caráter duplamente instrumental (técnico e simbólico) da atividade humana. 
Dessa forma, determinadas funções psicológicas têm seu desenvolvimento garantido pelo aparato biológico: trata-se das funções psíquicas elementares ou primitivas, que são comuns a homens e animais e caracterizam-se por uma relação imediata entre organismo e meio (ou entre estímulo e resposta). Assim, a aparição de um rato provoca de forma imediata e involuntária a reação de atenção do gato, da mesma forma que o contato da pele com o fogo provoca de forma imediata a reação motora de afastamento da fonte de calor e um determinado som no ambiente (sirene, alarme etc.) provoca de forma involuntária a reação de atenção no indivíduo. No entanto, o psiquismo humano não se resume às funções elementares.

O homem supera a relação imediata com a estimulação do meio, avançando na direção do domínio da própria conduta. A possibilidade de domínio dos próprios processos psicológicos é exclusivamente humana e caracteriza o que Vigotski (1995, p.90) denominou funções psicológicas superiores. Segundo o autor, a peculiaridade da conduta humana "em primeiro lugar se deve a que o homem intervém ativamente em suas relações com o meio e que, através do meio ele mesmo modifica seu próprio comportamento, submetendo-o a seu poder". Desse modo, o traço característico da operação psíquica superior é o domínio do próprio processo de comportamento por meio da introdução de signos.

Vigotski (1995) define o signo como um estímulo-meio artificial introduzido pelo homem na situação psicológica que constitui um meio para dominar a conduta (própria ou alheia). A origem (estímulo introduzido pelo próprio homem) e a função (meio para dominar a conduta) são os aspectos fundamentais dessa definição. Com a introdução do signo, a reação antes imediata e direta converte-se em uma reação mediada. A conduta humana, portanto, é regida por um novo princípio regulador: o princípio da significação (criação e o emprego de signos). Para Vigotski (1995), os signos mais importantes são as palavras, o que evidencia a importância da linguagem na formação dos processos psicológicos superiores humanos.

A introdução do signo permite ao homem dominar os próprios processos de comportamento. Torna-se possível controlar volunta- 
riamente a atenção e memorizar intencionalmente uma determinada informação. Enquanto a atenção involuntária é completamente determinada pela força e intensidade dos estímulos do meio, o homem se torna capaz de dirigir sua atenção a um alvo conscientemente estabelecido. Enquanto na memória natural "algo se memoriza”, na memória cultural, com a ajuda dos signos, "o homem memoriza algo” (ibidem). É assim que nos tornamos capazes de permanecer horas concentrados na leitura de um livro ou no estudo de um texto, ignorando sons e imagens do ambiente. Essa não é uma capacidade biologicamente determinada, mas uma conquista histórica e cultural do gênero humano que deve ser apropriada pelos indivíduos em seu processo de vida.

Dessa forma, ao longo de seu desenvolvimento, a criança assimila as formas sociais da conduta e as transfere para si mesma, ou seja, a criança começa a aplicar a si própria as mesmas formas de comportamento que a princípio outros aplicavam a ela. Essa lei é válida, de acordo com Vigotski (1995, p.146-7), para todo emprego de signos:

O signo, a princípio, é sempre um meio de relação social, um meio de influência sobre os demais e tão somente depois se transforma em meio de influência sobre si mesmo. [...] é certo que o signo foi a princípio um meio de comunicação e tão somente depois passou a ser um meio de conduta da personalidade.

Assim, Vigotski (1995, p.150) irá postular que "toda função psíquica superior passa inevitavelmente por uma etapa externa de desenvolvimento porque a função, a princípio, é social". Nessa direção, o autor postula o que ele denomina lei genética geral do desenvolvimento cultural: "toda função no desenvolvimento cultural da criança aparece duas vezes, em dois planos; primeiro no plano social e depois no psicológico, a princípio entre os homens como categoria interpsíquica e logo no interior da criança como categoria intrapsíquica" (ibidem). Essa lei aplica-se ao desenvolvimento da atenção voluntária, da memória lógica, da formação de conceitos e do desenvolvimento da vontade. 
As funções psíquicas superiores constituem, portanto, relações interiorizadas de ordem social. Os experimentos realizados pelo autor com grupos de crianças demonstram, por exemplo, que a reflexão interna nasce a partir de discussões no coletivo, isto é, as funções superiores do intelecto se manifestam inicialmente na interação entre as crianças no coletivo e na relação entre as crianças e o adulto/educador e só posteriormente aparecem como aquisições de sua própria conduta. Vale ressaltar que, para Vigotski, a passagem do externo ao interno modifica o próprio processo, transformando sua estrutura e funções.

Segundo Vigotski (1995), com a introdução de signos culturais, as operações psíquicas da criança se reorganizam, na direção do autodomínio de seus processos de comportamento. Dessa forma, o desenvolvimento da atenção voluntária, por exemplo, depende da introdução de meios auxiliares externos na situação psicológica, os quais serão internalizados pela criança. Do mesmo modo, o desenvolvimento da memória voluntária se efetiva na medida em que a criança assimila e internaliza técnicas culturais de memorização.

O postulado de que as funções psíquicas superiores são relações internalizadas de ordem social é coerente com a perspectiva de Leontiev (1978), que afirma que as novas aptidões e funções psíquicas formam-se no indivíduo por meio do processo de apropriação da cultura. Leontiev (1978) demonstra que as funções e aptidões especificamente humanas não se transmitem pela via da hereditariedade, mas fixam-se sob uma forma objetiva, exterior aos indivíduos, nos produtos da atividade humana, devendo ser apropriadas pelo indivíduo singular na ontogênese. A criança apropria-se, assim, do patrimônio cultural humano-genérico. ${ }^{6}$

O processo de apropriação, em sua análise, se dá justamente por meio da atividade da criança: ela deve reproduzir a atividade adequada aos objetos da cultura (material e não material). A mediação

6 Conforme Duarte (2001, p.93), “o indivíduo humano se faz humano apropriando-se da humanidade produzida historicamente. O indivíduo se humaniza reproduzindo as características historicamente produzidas do gênero humano". 
do adulto se mostra essencial nesse processo, tendo em vista que a atividade adequada não se forma espontaneamente na criança, pelo contato direto e imediato com os objetos da cultura. Embora em tais objetos estejam encarnados os modos de ação e as faculdades humanas historicamente elaboradas, é necessária a mediação de outros homens para que se concretize o processo de apropriação:

As aquisições do desenvolvimento histórico das aptidões humanas não são simplesmente dadas aos homens nos fenômenos objetivos da cultura material e espiritual que os encarnam, mas são aí apenas postas. Para se apropriar destes resultados, para fazer deles as suas aptidões, "os órgãos da sua individualidade", a criança, o ser humano, deve entrar em relação com os fenômenos do mundo circundante através doutros homens, isto é, num processo de comunicação com eles. Assim, a criança aprende a atividade adequada. Pela sua função, este processo é, portanto, um processo de educação. (Leontiev, 1978, p.272, grifos do autor)

A análise dos autores acerca do desenvolvimento psicológico traz implicações diretas para o trabalho pedagógico, pois evidencia a dependência do desenvolvimento das funções psíquicas da criança em relação aos processos educativos. Na medida em que se conclui que as funções psíquicas superiores têm gênese fundamentalmente cultural e não biológica, torna-se evidente que o ensino não deve basear-se na expectativa da maturação espontânea dessas funções (nem tomar tal maturação como condição prévia para as aprendizagens), mas, ao contrário, é responsável por promover seu desenvolvimento. Torna-se evidente também que o desenvolvimento dessas funções não está garantido pelo aparato biológico e pode não acontecer em plenitude se não forem proporcionadas as condições educativas adequadas para esse desenvolvimento. Se não forem garantidos processos educativos que tenham por finalidade promover a apropriação de formas superiores de conduta, a criança não incorporará tais funções em seu psiquismo. 


\section{Desenvolvimento, ensino e aprendizagem}

Vigotski (2001b, p.115) afirma que a aprendizagem constitui um elemento necessário e universal no desenvolvimento das características humanas formadas historicamente na criança:

A aprendizagem não é, em si mesma, desenvolvimento, mas uma correta organização da aprendizagem conduz ao desenvolvimento mental, ativa todo um grupo de processos de desenvolvimento, e esta ativação não poderia produzir-se sem a aprendizagem. Por isso, a aprendizagem é um momento intrinsecamente necessário e universal para que se desenvolvam na criança essas características humanas não-naturais, mas formadas historicamente. [...] todo o processo de aprendizagem é uma fonte de desenvolvimento que ativa numerosos processos, que não poderiam desenvolver-se por si mesmos sem a aprendizagem.

O ensino e a aprendizagem são, portanto, compreendidos como "fonte de desenvolvimento". Isso não significa que cada etapa da aprendizagem corresponda a uma etapa no desenvolvimento, ou seja, não há correspondência direta, linear e imediata entre o ensino e o desenvolvimento de determinada função: "no momento da assimilação de alguma operação aritmética, de algum conceito científico, o desenvolvimento dessa operação e desse conceito não termina mas apenas começa" (Vigotski, 2001a, p.324). Contudo, os processos de desenvolvimento não poderiam produzir-se "por si mesmos sem a aprendizagem".

Para promover a correta organização da aprendizagem mencionada pelo autor, o ensino deve adiantar-se ao desenvolvimento. Para Vigotski (2001a, p.333), o bom ensino é aquele que conduz o desenvolvimento, atuando sobre aquilo que ainda não está formado na criança: "o ensino deve fazer o desenvolvimento avançar".

Atuar sobre aquilo que ainda não está formado na criança significa atuar na zona de desenvolvimento potencial (ZDP). Para Vigotski (2001a), os processos psíquicos já plenamente desenvolvidos, os 
quais a criança domina com autonomia, constituem o desenvolvimento real/atual da criança; a ZDP, por sua vez, corresponde às funções psíquicas que estão iniciando seu ciclo de desenvolvimento, as quais a criança só é capaz de empregar com auxílio do educador (ou de crianças mais experientes). Para fazer o desenvolvimento avançar, o ensino não pode se limitar a aproveitar as possibilidades do desenvolvimento real, mas agir sobretudo na ZDP, ativando novos processos internos de desenvolvimento.

Aquelas funções psíquicas que hoje estão situadas na ZDP e cujo emprego pela criança só é possível com ajuda, irão, num segundo momento, converter-se em desenvolvimento real. Diante desse postulado, Davidov (1988) chama a atenção para as estreitas relações entre o conceito de zona de desenvolvimento potencial de Vigotski e sua formulação da lei genética geral do desenvolvimento cultural acima analisada. A ZDP refere-se aos processos que a criança consegue realizar apenas em colaboração com outros, na atividade coletiva, ou seja, que só podem efetivar-se no plano interpsíquico. $\mathrm{O}$ que a criança é capaz de fazer hoje no plano interpsíquico, conseguirá fazer amanhã com autonomia, no plano intrapsíquico, como conquista de seu desenvolvimento psíquico individual.

Com o conceito de ZDP, segundo Vigotski (1995), altera-se profundamente a concepção sobre as relações entre educação e desenvolvimento. Tradicionalmente, observa-se a preocupação em se adaptar a educação ao desenvolvimento, respeitando os prazos, o ritmo, as características do pensamento e da percepção infantis. $\mathrm{O}$ novo enfoque não deixa de buscar tal apoio, mas com a finalidade de superá-lo:

Para o novo ponto de vista seria uma loucura se nas classes escolares não se tivesse em conta a índole concreta e imaginativa da memória infantil: ela é o que deve servir de suporte; mas seria também uma loucura cultivar este tipo de memória, pois significaria reter a criança em uma etapa do inferior do desenvolvimento e não compreender que o tipo de memória concreta não é mais que uma etapa de transição, de passagem ao tipo superior, que a memória concreta deve ser superada no processo educativo. (ibidem, p.307) 
Assim, fica claro que, para Vigotski (2001a, p.334), o ensino deve produzir o novo no desenvolvimento psíquico da criança, afinal: "o ensino seria totalmente desnecessário se pudesse utilizar apenas o que já está maduro no desenvolvimento, se ele mesmo não fosse fonte de desenvolvimento e surgimento do novo".

\section{A importância da imitação}

Uma importante constatação de nossa pesquisa é que a imitação é apontada como um aspecto fundamental nos processos de ensino, aprendizagem e desenvolvimento. Trata-se, para Vigotski(1995), de uma das vias fundamentais de desenvolvimento cultural, pela qual a criança avança nas suas potencialidades intelectuais: "a imitação, se concebida em sentido mais amplo, é a forma principal em que se realiza a influência da aprendizagem sobre o desenvolvimento" (Vigotski, 1996, p.331).

Para Vigotski (2001a), o desenvolvimento decorrente da "colaboração via imitação..." é a fonte do surgimento de todas as propriedades especificamente humanas da consciência. Isso porque a imitação não é uma simples transferência mecânica da conduta de um ser a outro, mas implica uma determinada compreensão do significado da ação do outro.

Reside aí a grande diferença entre a imitação humana e animal. Diferentemente do homem, o animal não é capaz de assimilar nada essencialmente novo ou desenvolver suas faculdades intelectuais por meio da imitação: "é possível afirmar que o animal não pode ser ensinado, se entendermos o ensino no sentido específico do homem" (Vigotski, 2001a, p.331). Na imitação propriamente humana, a conduta a ser imitada precisa ser em alguma medida compreendida pela criança, ou seja, a imitação só é possível se acompanhada do entendimento. Por isso, nem tudo pode ser imitado pela criança: "a criança só consegue imitar o que se encontra na zona das suas próprias potencialidades intelectuais" (ibidem, p.328). 
Dessa forma, Vigotski (1995, p.138) assevera que é preciso renunciar "à idéia que reduz a essência da imitação à simples formação de hábitos e compreender a imitação como um fator essencial no desenvolvimento das formas superiores do comportamento humano".

Referindo-se ao ensino escolar, o pesquisador afirma que "a aprendizagem na escola se organiza amplamente com base na imitação. Porque na escola a criança não aprende o que sabe fazer sozinha mas o que ainda não sabe e lhe vem a ser acessível em colaboração com o professor e sob sua orientação" (Vigotski, 2001a, p.331).

Tal constatação assume grande importância no atual contexto das teorias pedagógicas, uma vez que a imitação tem sido indistintamente considerada prejudicial ao desenvolvimento da autonomia da criança e recusada como ferramenta do trabalho pedagógico.

\section{O caráter diretivo do trabalho educativo}

Como vimos, Vigotski (1995) destaca a mediação do adulto no processo de desenvolvimento das funções psicológicas superiores da criança e postula que o ensino deve promover o desenvolvimento. $\mathrm{Na}$ perspectiva do autor, o desenvolvimento cultural tem sempre como ponto de partida a atuação de outras pessoas sobre a criança:

Sabemos que a continuidade do desenvolvimento cultural da criança é a seguinte: primeiro outras pessoas atuam sobre a criança; se produz então a interação da criança com seu entorno e, finalmente, é a própria criança quem atua sobre os demais e tão somente ao final começa a atuar em relação consigo mesma. Assim é como se desenvolve a linguagem, o pensamento e todos os demais processos superiores de conduta. (ibidem, p.232)

Conclui-se, assim, que o desenvolvimento das diversas funções psíquicas superiores tem como condição uma operação cultural organizada, em princípio, pelo adulto, postulado que pode ser ilustrado na análise do autor do desenvolvimento da atenção mediada: 
Vemos, portanto, que o desenvolvimento da atenção da criança, desde os primeiros dias de sua vida, se encontra em um meio complexo formado por estímulos de duplo gênero. Por um lado, os objetos e fenômenos atraem a atenção da criança em virtude de suas propriedades intrínsecas; por outro, os correspondentes estímulos-catalisadores, isto é, as palavras orientam a atenção da criança. Desde o princípio, a atenção da criança está orientada. Primeiro a dirigem os adultos, mas à medida que a criança vai dominando a linguagem, começa a dominar a mesma propriedade de dirigir sua atenção em relação com os demais e depois em relação consigo mesma. (ibidem, p.232)

De acordo com Leontiev (2001a), podemos estabelecer como uma lei geral do desenvolvimento psicológico infantil que o desenvolvimento das funções psicológicas encontra-se na dependência dos processos concretos nos quais estão envolvidos, ou seja, se processa na e pela atividade da criança:

Qualquer função se desenvolve e é reestruturada dentro do processo que a realiza. As sensações, por exemplo, incrementam-se em conexão com o desenvolvimento dos processos de percepção dirigidos por um alvo. É por isso que elas podem ser ativamente cultivadas em uma criança, e seu cultivo não pode, de mais a mais, em virtude disso, consistir em um treinamento simples e mecânico das sensações em exercícios formais. (ibidem, p.77, grifo nosso)

Fica evidente que as funções psicológicas devem ser "cultivadas" na criança pelo educador e que isso não significa submeter a criança a um treinamento mecânico. Ao contrário, se o trabalho educativo se resumir a esse treinamento mecânico, o desenvolvimento dessas funções não se efetivará plenamente, em suas máximas possibilidades. É preciso, outrossim, que tais funções integrem processos dirigidos por um alvo, ou seja, é preciso que seu desenvolvimento se coloque como condição para a realização da atividade pela criança. Leontiev 
(2001a) ilustra esse processo com o desenvolvimento da audição fonemática na criança e a aprendizagem de uma língua estrangeira: ${ }^{7}$

Quando a criança começa a estudar uma língua estrangeira, no começo não ouve a diferença entre fonemas semelhantes, que são novos para ela, como a diferença, por exemplo, entre o som vocálico em francês em mais e mes. Além disso, é notável o fato de que para se tornar sensível a esta diferença não basta ouvir freqüentemente falar a língua francesa, sem todavia tentar dominá-la. É isso que torna possível que alguém passe muitos anos entre pessoas que falam outra língua e, mesmo assim, permaneça surdo às nuanças de sua fonética. (ibidem, p.78)

A constatação de que as funções psicológicas que o educador pretende desenvolver no aluno devem ser requeridas por atividades em que esteja colocada, em alguma medida, a intencionalidade da criança (a busca pela consecução de determinado objetivo), evidencia que não basta expor a criança a estímulos diversos, ou seja, não basta disponibilizar a ela os objetos da cultura - para além disso, é preciso organizar sua atividade.

Nesse sentido, Leontiev (2001a, p.63) preconiza a necessidade da análise do conteúdo da atividade da criança e de investigações que revelem como essa atividade é constituída nas condições concretas de vida:

Só com esse modo de estudo, baseado na análise do conteúdo da própria atividade infantil em desenvolvimento, é que podemos compreender de forma adequada o papel condutor da educação e da criação, operando precisamente em sua atividade e em sua atitude diante da realidade, e determinando, portanto, sua psique e sua consciência.

Destacamos do trecho citado a referência ao papel do trabalho educativo, que deve "operar precisamente" na atividade da criança e em sua atitude perante o mundo e, com isso, "determinar" seu

7 Na obra "A construção do pensamento e da linguagem, Vigotski (2001a) apresenta análise semelhante acerca da necessária intencionalidade que deve permear o processo de aquisição de uma língua estrangeira. 
psiquismo e sua consciência. Leontiev não deixa dúvidas quanto ao papel diretivo do trabalho do educador na promoção do desenvolvimento da criança: o educador opera sobre a atividade da criança e determina o desenvolvimento de seu psiquismo. Tal afirmação se mostra bastante relevante em nossa investigação, pois se opõe diretamente à concepção do educador como alguém que deve limitar-se a "seguir as crianças". Na perspectiva do autor, a análise da atividade da criança visa justamente fornecer ao educador subsídios para uma intervenção mais precisa e eficaz no desenvolvimento infantil.

Nessa mesma direção, Vigotski (2001a, p.248) se mostra crítico em relação aos métodos de educação que preconizam a espontaneidade e a passividade, como fica evidente em sua análise sobre o pensamento de Tolstói:

$\mathrm{O}$ aspecto falso dessa tese, diretamente ligado às concepções gerais de Tolstói sobre educação, consiste em que ele exclui qualquer possibilidade de intervenção grosseira nesse processo misterioso, procura deixar o processo de desenvolvimento dos conceitos à mercê das leis do seu próprio fluxo interno, negando, assim, o desenvolvimento dos conceitos a partir da aprendizagem e condenando o ensino à mais total passividade na questão do desenvolvimento dos conceitos científicos. Esse erro se manifesta com especial nitidez na formulação categórica segundo a qual "toda interferência é uma força bruta, desajeitada, que retém o processo de desenvolvimento". [...] Tolstói dá importância exagerada à espontaneidade, ao acaso, ao trabalho de um conceito e de uma sensibilidade vagos, ao aspecto interior da formação dos conceitos, fechado em si mesmo, [...] distancia exageradamente aprendizagem e desenvolvimento. (grifos nossos)

\section{Os períodos do desenvolvimento infantil e o ensino de 0 a 6 anos}

Assim como Vigotski e Leontiev, Elkonin (1960, p.498) enfatiza o papel diretivo do adulto no processo educativo. Para o autor: 
O desenvolvimento psíquico das crianças tem lugar no processo de educação e ensino realizado pelos adultos, que organizam a vida da criança, criam condições determinadas para seu desenvolvimento e lhe transmitem a experiência social acumulada pela humanidade no período precedente de sua história. Os adultos são os portadores dessa experiência social. Graças aos adultos a criança assimila um amplo círculo de conhecimentos adquiridos pelas gerações precedentes, aprende as habilidades socialmente elaboradas e as formas de conduta criadas na sociedade. À medida que assimilam a experiência social se formam nas crianças distintas capacidades. (grifos no original)

De acordo com o autor, portanto, o desenvolvimento psíquico se efetiva mediante a apropriação da experiência social, num processo organizado e dirigido pelo adulto. Não obstante, Elkonin (1960, p.498) chama a atenção para o fato de que nem todos os atos dos adultos têm suficiente influência sobre o desenvolvimento da criança:

Nem todo conhecimento recebido [...] influi sobre a formação da personalidade e na conduta da criança. Não qualquer maneira de adquirir os conhecimentos desenvolve as capacidades intelectuais e a atividade intelectual. [...]. O desenvolvimento do psiquismo não reflete de maneira automática tudo o que atua sobre a criança. O efeito dos agentes externos, a influência da educação e do ensino, dependem de como se realizam estas influências e do terreno já anteriormente formado sobre o qual recaem.

Esse postulado recoloca o problema da organização do ensino:

Pelo fato de que o desenvolvimento psíquico das crianças não reflete automaticamente tudo o que atua sobre elas não se deve subestimar, de forma alguma, o papel diretor do ensino e da educação em seu desenvolvimento, mas se faz indispensável uma organização tal que possibilite os melhores resultados e tenha a maior influência em sua formação integral. (ibidem, p.499) 
Tal organização adequada do ensino implica, para Elkonin (1960), garantir que a intervenção pedagógica esteja de acordo com as particularidades de cada idade ou período do desenvolvimento. ${ }^{8}$ Tendo isso em vista, uma das frentes de investigação de nossa pesquisa consistiu na caracterização dos períodos ou estágios do desenvolvimento infantil até a transição à idade escolar, buscando compreender o papel do ensino e do educador em cada um desses estágios. Apresentaremos, de forma breve, algumas de nossas principais constatações.

Um primeiro importante aspecto da periodização do desenvolvimento em uma perspectiva histórico-cultural refere-se à sua concepção como processo que combina processos evolutivos e revolucionários, consubstanciada na noção de crise, introduzida por Vigotski. Na perspectiva do autor, o desenvolvimento infantil não constitui um processo puramente quantitativo/evolutivo, mas caracteriza-se por rupturas e saltos qualitativos:

O desenvolvimento não se produz pela via de mudanças graduais, lentas, por uma acumulação de pequenas peculiaridades que produzem em seu conjunto e ao final alguma mudança importante. [...] observamos a existência de mudanças bruscas e essenciais no próprio tipo de desenvolvimento, nas próprias forças motrizes do processo. (Vigotski, 1995, p.156)

Evolução e revolução constituem, em uma perspectiva dialética, duas formas de desenvolvimento vinculadas entre si, que se pressupõem reciprocamente. Assim, a transição entre um estágio e outro do desenvolvimento não constitui uma mera mudança quantitativa/ de grau, mas uma mudança qualitativa. A cada novo estágio do desenvolvimento modifica-se o tipo de relação que a criança estabelece com o meio e com as pessoas que a rodeiam por meio de sua

8 Apoiado no conceito de ZDP, Elkonin (1960) alerta que considerar as particularidades psicológicas de cada fase do desenvolvimento não significa que o pedagogo deva orientar-se somente pelo nível de desenvolvimento já alcançado e típico para a idade, pois sua missão é fazer avançar o desenvolvimento psíquico das crianças. 
atividade; modificam-se suas necessidades e motivos e as qualidades de seu psiquismo.

Para Vigotski (1995), a transição a um novo estágio do desenvolvimento se caracteriza pela ocorrência de crises. Nos períodos de crise, produzem-se mudanças e rupturas bruscas e fundamentais na personalidade da criança em um tempo relativamente curto, culminando em uma reestruturação das necessidades e motivos da criança e de sua relação com o meio. Leontiev (2001a, p.67), por sua vez, considera que as crises não são inevitáveis:

Na realidade, as crises não são absolutamente acompanhantes do desenvolvimento psíquico. Não são as crises que são inevitáveis, mas o momento crítico, a ruptura, as mudanças qualitativas no desenvolvimento. A crise, pelo contrário, é a prova de que um momento crítico ou uma mudança não se deu em tempo. Não ocorrerão crises se o desenvolvimento psíquico da criança não tomar forma espontaneamente e, sim, se for um processo racionalmente controlado, uma criação controlada.

Esse trecho traz, de forma clara, a perspectiva de Leontiev (2001a) de que o educador não pode limitar-se a "acompanhar" ou "seguir" o desenvolvimento espontâneo da criança, mas, ao contrário, deve dirigir ou controlar racionalmente esse processo. Cabe esclarecer que uma "criação controlada" em nada se aproxima de um processo que supostamente cercearia a criatividade, a iniciativa e a liberdade da criança. ${ }^{9}$ Leontiev (1978) defende que o professor conheça profundamente o processo de desenvolvimento infantil e suas forças motrizes, para que, de posse de tal conhecimento, possa estabelecer finalidades e objetivos pedagógicos adequados e organizar atividades pedagógicas que promovam o desenvolvimento da criança. Em relação especificamente aos períodos de ruptura e salto qualitativo no desenvolvimento, o professor deve apresentar novas tarefas e

9 Mesmo porque, a criatividade, a iniciativa e a liberdade não são características dadas a priori na criança, mas possibilitadas justamente pelo processo educativo. 
exigências que correspondam às potencialidades em mudança da criança e à sua nova percepção da realidade.

Apoiados nos pressupostos vigotskianos, Leontiev e Elkonin analisarão a questão da periodização do desenvolvimento tomando como eixo fundamental a categoria de atividade principal. Como vimos, para Leontiev (2001a) o que determina diretamente o desenvolvimento da psique da criança é o desenvolvimento de seus processos reais de vida, isto é, o desenvolvimento de sua atividade. $\mathrm{Na}$ análise do autor, corroborada por Elkonin, determinados tipos de atividade são mais importantes para o desenvolvimento em determinados estágios do desenvolvimento. Temos aí o conceito de a atividade principal, que se refere à atividade cujo desenvolvimento governa as mudanças mais importantes nos processos psíquicos e traços psicológicos da personalidade da criança em cada estágio de seu desenvolvimento. ${ }^{10}$ A partir desse postulado, Elkonin (1987b) propõe um esquema de periodização do desenvolvimento infantil, o qual apresentaremos de forma breve e que evidencia o papel dos processos educativos em cada um dos estágios.

A atividade principal da criança no primeiro ano de vida é a comunicação emocional direta. $\mathrm{O}$ bebê utiliza vários recursos para se comunicar com os adultos, como o choro, o sorriso e o balbucio, e no interior dessa atividade (e a partir dela) tomam forma as ações sensório-motoras, de orientação e manipulação. A respeito do papel do adulto/ educador nessa fase do desenvolvimento Elkonin (1960, p.507) afirma:

Neste período todas as aquisições da criança aparecem sob a influência imediata dos adultos, que não somente satisfazem todas as suas necessidades, mas organizam também seu contato variado com a realidade, sua orientação nela e as ações com os objetos. O adulto leva

10 A atividade principal tem três características básicas para Leontiev (2001a), quais sejam: a) é a atividade no interior da qual surgem e se diferenciam outros tipos de atividade; b) é aquela na qual os processos psíquicos particulares tomam forma ou são reorganizados; c) é a atividade da qual dependem, de forma mais íntima, as principais mudanças psicológicas na personalidade infantil. 
à criança distintas coisas para que as contemple, movimenta junto com ela o chocalho, coloca em suas mãos os primeiros objetos para que os segure; a criança aprende a sentar-se com ajuda do adulto, o adulto a sustenta em suas primeiras tentativas de colocar-se em pé e andar, etc. (grifos nossos)

Posteriormente, converte-se em atividade principal a atividade objetal manipulatória, ou seja, a criança passa às ações propriamente objetais, iniciando-se no domínio dos procedimentos socialmente elaborados de ações com tais objetos. Verifica-se, nesse período, um ativo domínio das operações objetais-instrumentais e o desenvolvimento da chamada inteligência prática. Vale ressaltar que o domínio dessas ações é impossível sem a participação dos adultos, que as mostram para a criança e as realizam juntamente com ela. Conforme Elkonin (1987b), o adulto constitui o elemento mais importante da situação objetal, mas pode-se dizer que permanece "oculto" pelo objeto e por suas propriedades, na medida em que a criança ocupa-se fundamentalmente com o objeto e sua ação com ele.

Um elemento fundamental desse período é o surgimento das formas verbais de comunicação da criança com os adultos. Vigotski (1996, p.356-7) destaca o papel do adulto no desenvolvimento da linguagem na primeira infância, afirmando que "são eles [os adultos] que impulsionam a criança a uma nova via de generalização, ao domínio da linguagem". A análise dos contatos verbais da criança mostra que a linguagem é utilizada por ela essencialmente no contato prático entre adulto e criança, isto é, para organizar a colaboração com os adultos no interior da atividade objetal conjunta (Elkonin, 1987b). A comunicação emocional direta com o adulto passa, portanto, a um segundo plano e ganha destaque a colaboração prática. Assim, tanto a linguagem atua como meio para organizar a comunicação com o adulto quanto a comunicação mesma está mediada pelas ações objetais da criança.

No período seguinte, a idade pré-escolar, que se estende em geral do terceiro até o sexto ano de vida, a atividade principal é o jogo de papéis. Por meio dessa atividade as crianças reproduzem e apropriam-se das relações sociais e do sentido social das atividades huma- 
nas (Leontiev, 2001a) e aprendem a subordinar seu comportamento às exigências do papel que representam (Elkonin, 1987a). Conforme Mukhina (1996, p.157), as crianças refletem no jogo a realidade que as circunda, de modo que "quanto mais ampla for a realidade que as crianças conhecem, tanto mais amplos e variados serão os argumentos de seus jogos". O inverso também é necessariamente verdadeiro, ou seja, quanto mais restrito for o contato da criança com a realidade social, mais pobres e monótonos serão os argumentos de seus jogos. Portanto, se o desenvolvimento do conteúdo dos jogos de papéis se relaciona diretamente com a ampliação e a sistematização de conhecimentos pela criança, cabe à escola de Educação Infantil organizar e ampliar ao máximo esse contato da criança com a realidade social.

Elkonin (1987a) afirma que as funções do pedagogo na organização do jogo infantil não são tão claras e definidas quanto em outras tarefas. Por isso, a análise da natureza do jogo deve permitir não apenas compreender a importância do jogo para o desenvolvimento da criança, "mas também dar-nos a chave para dominar o processo de jogo, para aprender a dirigi-lo conscientemente, para utilizá-lo como meio de educação e desenvolvimento da criança pré-escolar" (ibidem, p.85). Também Leontiev (2001b, p.122) considera que, sendo o jogo a atividade principal da criança nessa faixa etária, é fundamental para o educador "saber controlar o brinquedo de uma criança" sem incorrer, contudo, em uma "paralisação do brinquedo em vez de seu controle”. Nesse sentido, Elkonin (1960) é claro ao afirmar que a intervenção do professor no jogo não implica na supressão do caráter independente e criativo da atividade lúdica.

$\mathrm{Na}$ Educação Infantil, é preciso ensinar na e pela brincadeira. É preciso, para isso, romper com a artificial dicotomia entre "atividades dirigidas" (supostamente para ensinar) e "atividades livres" (supostamente para brincar), ainda tão presente nas escolas de Educação Infantil. É papel do professor revelar para a criança, como indica Elkonin (1960), as facetas da realidade que ela somente pode conhecer pela via de sua mediação - tendo em vista o postulado de Leontiev (1978) de que os objetos e fenômenos da cultura não podem ser apropriados imediatamente pela criança: 
O conteúdo dos jogos de argumento tem uma significação educativa importante. Por isso é preciso observar com cuidado do que brincam as crianças. É preciso dar-lhes a conhecer aquelas facetas da realidade cuja reprodução nos jogos pode exercer uma influência educativa positiva e distraí-las da representação daquilo que possa desenvolver qualidades negativas. (Elkonin, 1960, p.513, grifos no original)

Na perspectiva de Elkonin (1987a), a intervenção do professor pode se dar tanto na seleção de temas para a brincadeira quanto na distribuição dos papéis entre as crianças e sugestão/definição dos acessórios a serem utilizados. $\mathrm{O}$ autor esclarece ainda que os papéis propostos pelo educador às crianças podem ou não ser atrativos para elas, e serão tanto mais atrativos quanto mais repletos de ações saturadas de conteúdo e sentido e relações profundas com os outros papéis que compõem a brincadeira: "saturando o papel de conteúdo o tornamos mais atrativo, formamos o desejo da criança. Essa possibilidade de formar os desejos infantis, de dirigi-los, faz do jogo um poderoso meio educativo quando se introduzem nele temas que possuem grande importância para a educação" (ibidem, p.101).

\section{Atividade de estudo e preparação para a escola}

Com a transição à idade escolar, a atividade principal da criança passa a ser a atividade de estudo. Entretanto, na perspectiva de Elkonin (1960), a atividade de estudo não se inicia apenas com a transição à idade escolar, mas já na idade pré-escolar, embora não figure ainda como atividade principal. Nessa direção, apoiado na premissa de que a atividade principal é aquela na qual surgem e a partir da qual se diferenciam outros tipos de atividade, Leontiev (2001a, p.64) afirma que "a instrução, no sentido mais estreito do termo, que se desenvolve em primeiro lugar já na infância pré-escolar, surge inicialmente no brinquedo, isto é, precisamente na atividade principal deste estágio do desenvolvimento". Portanto, a instrução na idade pré-escolar deve estar a princípio organicamente vinculada à brincadeira. 
A proposição de atividades para as crianças cujo objetivo é adquirir conhecimentos e habilidades constitui, para Elkonin (1960), um importante aspecto da preparação para a escola. O autor postula que o desenvolvimento da criança no início da escola depende em grande medida do grau de preparação com que chega a ela, o que, por sua vez, é determinado pela educação na primeira infância e na idade pré-escolar. Além disso, chama a atenção para os possíveis prejuízos que a ausência de um trabalho pedagógico consistente e de qualidade na faixa etária anterior à idade escolar pode acarretar ao posterior desenvolvimento da criança:

Também se encontram crianças que, embora desde o princípio demonstrem uma atitude cuidadosa em relação ao estudo, não podem realizar as tarefas da escola porque na idade pré-escolar não lhes haviam ensinado a fazer esforços mentais. [...] A essas crianças não foi ensinado a pensar, por isso não sabem e não gostam de fazê-lo [...]. (ibidem, p.524, grifos nossos)

As afirmativas do autor nos levam a uma importante conclusão: a educação da criança de 0 a 6 anos tem como uma de suas tarefas fundamentais "ensinar a pensar". Tal proposição sustenta-se na compreensão de que o pensamento não se desenvolve natural ou espontaneamente na criança, como resultado da maturação orgânica, mas como resultado do processo educativo. Fica evidente, ainda, que uma educação meramente e exclusivamente calcada no prazer, que não exija da criança pequena "esforços mentais", não apenas desconsidera as futuras exigências que se colocarão para ela na escola como pode retardar as aprendizagens escolares, por não ter garantido suas premissas.

Outra importante conclusão refere-se à vinculação mais estreita que deveria existir entre a Educação Infantil e a séries iniciais do Ensino Fundamental. Elkonin (1987b) tem como hipótese que a idade pré-escolar e a idade escolar compõem uma mesma época do desenvolvimento infantil.

Buscando captar a unidade entre os aspectos intelectual e afetivo no desenvolvimento da personalidade, Elkonin (1987b) sugere 
que os períodos do desenvolvimento infantil podem ser agrupados em épocas, quais sejam: primeira infância, infância e adolescência. Cada época seria constituída de um período em que prepondera o desenvolvimento afetivo-motivacional (pela apropriação dos sentidos fundamentais das atividades humanas), seguido de um período em que prepondera o desenvolvimento intelectual-cognitivo (pela apropriação de habilidades e procedimentos socialmente elaborados de ação com os objetos). A idade pré-escolar, nesse sentido, promoveria o desenvolvimento de novos motivos e necessidades na criança, "preparando o terreno" para as habilidades cognitivas a serem amplamente desenvolvidas na idade escolar. Sendo assim:

De acordo com as exigências que se depreendem dessa hipótese, ali onde no sistema atual se observa uma ruptura (instituição pré-escolar - escola) deve existir uma vinculação mais orgânica. Por outro lado, ali onde existe hoje uma continuidade (graus primários - graus médios) deve haver uma passagem a um novo sistema educativo e de ensino. (ibidem, p.124)

Assim, a idade pré-escolar e a primeira idade escolar apresentam importantes vinculações que merecem ser exploradas pelos pesquisadores, movimento que não se tem observado na literatura. Não se trata de reafirmar a preparação para a escola como função precípua da Educação Infantil, mas é preciso reconhecer que, na busca pela especificidade e identidade própria do trabalho pedagógico junto à criança de 0 a 6 anos, tem-se incorrido, muitas vezes, no equivocado rompimento do vínculo entre essas fases do desenvolvimento.

\section{Em defesa do ensino na Educação Infantil}

À guisa de conclusão e resgatando os questionamentos apresentados no início do texto, acreditamos ter demonstrado que a defesa do ensino decorre da própria concepção de desenvolvimento infantil da psicologia histórico-cultural, na medida em que se refuta 
a compreensão do desenvolvimento como processo espontâneo e natural, compreende-se o ensino como fonte de desenvolvimento e evidencia-se a importância das condições de vida e educação e da intervenção do adulto.

Na perspectiva da psicologia histórico-cultural, o educador não pode ser entendido como alguém que apenas estimula e acompanha a criança em seu desenvolvimento. Em contraposição a essa violenta descaracterização de seu papel subjacente à negação do ensino, que reduz sua interferência na sala de aula a uma mera participação (Arce, 2004), o professor é compreendido como aquele que transmite à criança os resultados do desenvolvimento histórico, explicita os traços da atividade humana cristalizada nos objetos da cultura mediando sua apropriação - e organiza a atividade da criança, promovendo assim seu desenvolvimento psíquico.

Dessa forma, se entendemos o ato de ensinar em oposição ao imperativo de "seguir as crianças...", ou seja, como intervenção intencional e consciente do educador que visa garantir a apropriação do patrimônio humano-genérico pela criança, promovendo e guiando seu desenvolvimento psíquico, podemos afirmar que os pressupostos de Vigotski, Leontiev e Elkonin sustentam a defesa do ensino junto à criança de 0 a 6 anos.

\section{Referências bibliográficas}

ANPED [Associação Nacional de Pesquisa e Pós-graduação em Educação]. Parecer da ANPEd sobre o documento Referencial Curricular Nacional para a Educação Infantil. Revista Brasileira de Educação, n.7, jan.-abr. 1998.

ARCE, A. Pedagogia da infância ou fetichismo da infância? In: DUARTE, N. (Org.) Crítica ao fetichismo da individualidade. Campinas: Autores Associados, 2004.

CERISARA, A. B. Por uma pedagogia da educação infantil: desafios e perspectivas para as professoras. Caderno Temático de Formação II Educação Infantil: construindo a Pedagogia da Infância no município de São Paulo. Secretaria Municipal de Educação. Diretoria de Orientação Técnica. São Paulo, SME DOT/ ATP/ DOT, 2004. 
DAVIDOV, V. Problemas del desarrollo psiquico de los niños. In: DAVIDOV, V. La enseñanza escolar e el desarrollo psiquico. Moscú: Editorial Progresso, 1988.

DUARTE, N. Educação escolar, teoria do cotidiano e a escola de Vigotski. Campinas: Autores Associados, 2001.

ELKONIN, D. B. Característica general del desarrollo psíquico de los niños. In: SMIRNOV, A. A.; LEONTIEV, A. N.; RUBINSHTEIN, S. L.; TIEPLOV, B. M. (Org.) Psicología. México: Grijalbo, 1960.

ELKONIN, D. Problemas psicológicos del juego en la edad preescolar. In: DAVÍDOV, V.; SHUARE, M. La psicologia evolutiva e pedagógica en la URSS. Moscú: Editorial Progresso, 1987a.

Sobre el problema de la periodización del desarrollo psíquico en la infancia. In: DAVÍDOV, V.; SHUARE, M. La psicologia evolutiva e pedagógica en la URSS. Moscú: Editorial Progresso, 1987b.

FACCI, M. G. D. Valorização ou esvaziamento do trabalho do professor? Um estudo crítico-comparativo da teoria do professor reflexivo, do construtivismo e da psicologia vigotskiana. Campinas: Autores Associados, 2004.

FARIA, A. L. G. O espaço físico como um dos elementos fundamentais para uma pedagogia da educação infantil. In: FARIA, A. L. G.; PALHARES, M. S. (Org.) Educação Infantil pós-LDB: rumos e desafios. Campinas: Autores Associados, 2005.

LEONTIEV, A. O desenvolvimento do psiquismo. Lisboa: Livros Horizonte, 1978.

Uma contribuição à teoria do desenvolvimento da psique infantil. In:VIGOTSKI, L. S.; LURIA, A. R.; LEONTIEV, A. N. Linguagem, desenvolvimento e aprendizagem. 9.ed. São Paulo: Ícone, 2001a.

Os princípios psicológicos da brincadeira pré-escolar. In: VIGOTSKI, L. S.; LURIA, A. R.; LEONTIEV, A. N. Linguagem, desenvolvimento e aprendizagem. 9.ed. São Paulo: Ícone, 2001b.

MUKHINA, V. Psicologia da idade pré-escolar. São Paulo: Martins Fontes, 1996.

PINO, A. O social e o cultural na obra de Lev S. Vigotski. Educação E Sociedade, Campinas, ano XXI, n.71, p.45-78, out. 2000.

ROCHA, E. A. C. A pesquisa em educação infantil no Brasil: trajetória recente e perspectiva de consolidação de uma pedagogia da educação infantil. Florianópolis: UFSC, Centro de Ciências da Educação, Núcleo de Publicações, 1999.

VIGOTSKI, L. S. Obras escogidas. Madrid: Visor, 1995. t.III.

Obras escogidas. Madrid: Visor, 1996. t.IV. 
A construção do pensamento e da linguagem. São Paulo: Martins Fontes, 2001a.

Aprendizagem e desenvolvimento intelectual na idade escolar. In: VIGOTSKI, L. S., LEONTIEV, A. N.; LURIA, A. R. Linguagem, desenvolvimento e aprendizagem. São Paulo: Ícone, 2001b.

VIGOTSKI, L. S.; LURIA, A. R. Estudos sobre a história do comportamento: símios, homem primitivo e criança. Porto Alegre: Artes Médicas, 1996. 


\author{
SOBRE O LIVRO \\ Formato: $14 \times 21 \mathrm{~cm}$ \\ Mancha: 23,7 x 42,5 paicas \\ Tipologia: Horley Old Style 10,5/14 \\ 1a edição: 2010 \\ EQUIPE DE REALIZAÇÃO \\ Coordenação Geral \\ Marcos Keith Takahashi
}

